\title{
CARACTERÍSTICAS ESTRUTURAIS DO DOSSEL FORRAGEIRO, VALOR NUTRITIVO E PRODUÇÃO DE FORRAGEM EM PASTOS DE CAPIM-MOMBAÇA SUBMETIDOS A REGIMES DE LOTAÇÃO INTERMITENTE
}

\author{
ADRIANA AMARAL DE OLIVEIRA BUENO
}

Dissertação apresentada à Escola Superior de Agricultura "Luiz de Queiroz", Universidade de São Paulo, para obtenção do título de Mestre em Agronomia, Área de Concentração: Ciência Animal e Pastagens.

P I R A C I C A B A

Estado de São Paulo - Brasil

Maio - 2003 


\title{
CARACTERÍSTICAS ESTRUTURAIS DO DOSSEL FORRAGEIRO, VALOR NUTRITIVO E PRODUÇÃO DE FORRAGEM EM PASTOS DE CAPIM-MOMBAÇA SUBMETIDOS A REGIMES DE LOTAÇÃO INTERMITENTE
}

\author{
ADRIANA AMARAL DE OLIVEIRA BUENO \\ Engenheira Agrônoma
}

Orientador: Prof. Dr. SILA CARNEIRO DA SILVA

\begin{abstract}
Dissertação apresentada à Escola Superior de Agricultura "Luiz de Queiroz", Universidade de São Paulo, para obtenção do título de Mestre em Agronomia, Área de Concentração: Ciência Animal e Pastagens.
\end{abstract}

P I R A C I C A B A

Estado de São Paulo - Brasil

Maio - 2003 


\section{Dados Internacionais de Catalogação na Publicação (CIP) DIVISÃO DE BIBLIOTECA E DOCUMENTAÇÃO - ESALQ/USP}

\section{Bueno, Adriana Amaral de Oliveira}

Características estruturas do dossel forrageiro, valor nutritivo e produção de

forragem em pastos de capim mombaça submetidos a regimes de lotação intermitente / Adriana Amaral de Oliveira Bueno. - - Piracicaba, 2003.

124 p. : il.

Dissertação (mestrado) - - Escola Superior de Agricultura Luiz de Queiroz, 2003.

Bibliografia.

1. Capim mombaça 2. Dossel forrageiro 3. Forragem 4. Pastejo 5. Valor nutritivo I. Título

CDD 633.2

\section{"Permitida a cópia total ou parcial deste documento, desde que citada a fonte - O autor"}


Aos meus pais, Carlos Alberto e Elizabeth, pelo carinho e compreensão ao longo das minhas conquistas,

\section{DEDICO.}

Ao Fernando, meu amado marido, testemunha e colaborador de mais essa etapa da minha vida, 


\section{AGRADECIMENTOS}

Ao Prof. Dr. Sila Carneiro da Silva pela oportunidade de sua orientação, pela atenção e pela paciência prestada na realização deste trabalho.

Aos professores do Departamento de Zootecnia que de alguma forma colaboraram no esclarecimento de dúvidas.

Ao Prof. Dr. Jozivaldo Prudêncio de Morais, pelo encaminhamento na minha vida profissional, pelo atenção e concessão dos animais e da área para a realização do experimento nas dependências da Universidade Federal de São Carlos.

À Universidade de São Paulo, por meio do Departamento Zootecnia, pela oportunidade de realização do curso.

Ao técnico de laboratório Carlos César Alves que, através de sua amizade, atenção e compreensão no laboratório de bromatologia, compartilhou voluntariamente seus conhecimentos tornando possível a conclusão deste trabalho.

Ao Dr. Fábio Prudêncio Campos, pelo apoio e atenção no esclarecimento de dúvidas na execução das análises laboratoriais.

À Roberta Aparecida Carnevalli, aluna de doutorado, responsável pela criação deste projeto e companheira das incansáveis horas de trabalho.

À Marina Castro Uebele, aluna de mestrado, que também compartilhou com companherismo as incansáveis horas de trabalho no campo.

Aos estagiários Fernando, Glaciliana e Rodrigo pela dedicação especial e companherismo.

Aos estagiários do Grupo de Estudo e Trabalhos Agropecuários (GETAP) pela ajuda nos trabalhos de campo.

À FAPESP pelo financiamento deste projeto através de Auxílo à Pesquisa.

À todos que direta ou indiretamente contribuíram para a realização do experimento. 


\section{SUMÁRIO}

\begin{tabular}{|c|c|}
\hline & Página \\
\hline RESUMO . & vii \\
\hline SUMMARY ............................ & ix \\
\hline 1 INTRODUÇÃO....... & 1 \\
\hline 2 REVISÃO DE LITERATURA... & 3 \\
\hline 2.1 O capim-Mombaça ............... & 3 \\
\hline 2.2 Plantas Forrageiras em Pastagens ....................................... & 4 \\
\hline 2.3 Composição morfológica e valor nutritivo da forragem ... & 6 \\
\hline 3 MATERIAL E MÉTODOS.. & 14 \\
\hline 3.1 Material... & 14 \\
\hline 3.1.1 Espécie vegetal, local e período do experimento & 14 \\
\hline 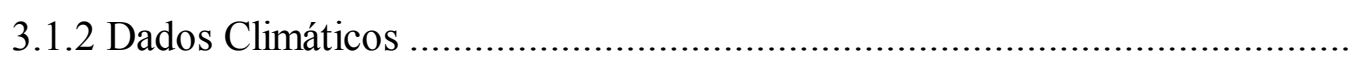 & 15 \\
\hline 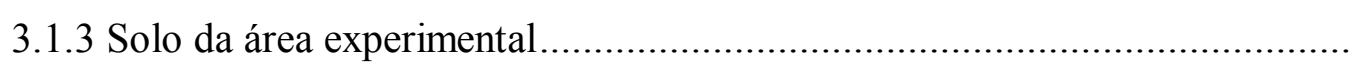 & 17 \\
\hline 3.2 Métodos................................. & 18 \\
\hline 3.2.1 Tratamentos e delineamento experimental ..................................... & 18 \\
\hline 3.2.2 Monitoramento das condições experimentais e adubação dos pastos ........... & 19 \\
\hline 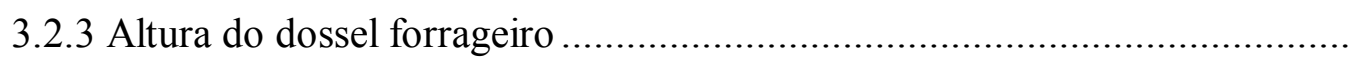 & 21 \\
\hline 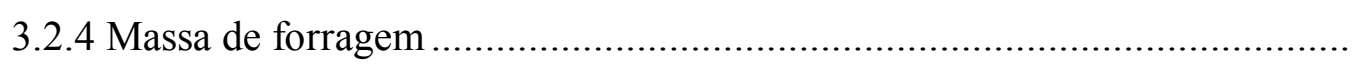 & 21 \\
\hline 3.2.5 Densidade volumétrica.... & 22 \\
\hline 3.2.6 Composição botânica e morfológica da forragem..... & 23 \\
\hline 3.2.7 Composição química ............ & 25 \\
\hline 3.2.8 Taxas de acúmulo e produção de forragem. & 26 \\
\hline 3.3 Análise estatística.. & 26 \\
\hline
\end{tabular}




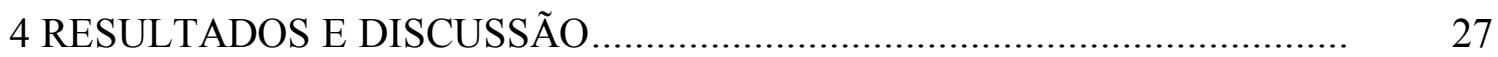

4.1 Intervalo médio entre pastejos ................................................................. 27

4.2 Características estruturais do dossel forrageiro .......................................... 30

4.2.1 Altura média em pré-pastejo ……............................................................. 30

4.2.2 Altura média em pós-pastejo ................................................................. 32

4.2.3 Massa de forragem do pasto em pré-pastejo ............................................. 36

4.2.4 Massa de forragem em pós-pastejo ……..................................................... 38

4.2.5 Densidade volumétrica......................................................................... 39

4.2.6 Composição botânica e morfológica ……………………………………... 41

4.2.6.1 Composição botânica............................................................................

4.2.6.2 Composiçõa morfológica ........................................................................

4.2.6.2.1 Material morto..............................................................................

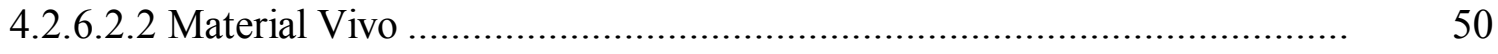

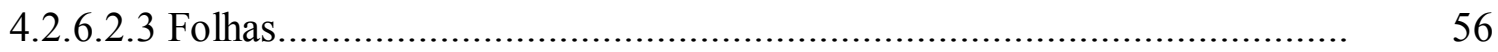

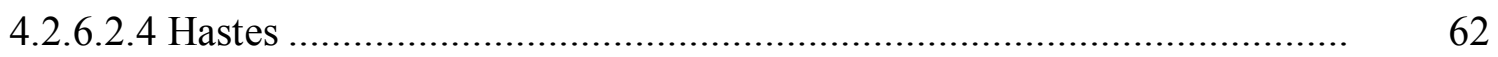

4.2.6.2.5 Hastes Florescidas .....................................................................

4.2.7 Composição Química................................................................................

4.2.7.1 Matéria Mineral...........................................................................

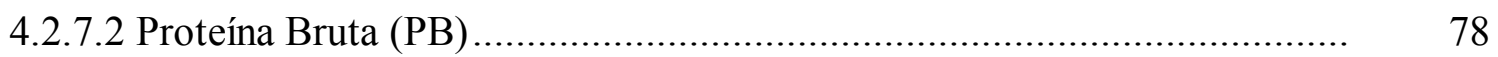

4.2.7.3 Fibra Insolúvel em Detergente Neutro (FDN) ………............................. 85

4.2.7.4 Fibra Insolúvel em Detergente Ácido (FDA) ........................................... 91

4.2.7.5 Digestibilidade in vitro da Matéria Orgânica (DIVMO)............................. 96

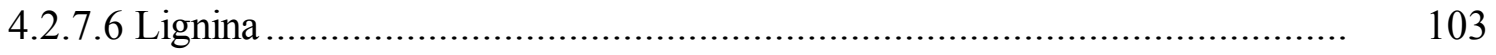

4.3 Produção de Forragem ............................................................................ 106

4.3.1 Taxa de acúmulo de massa seca ............................................................... 106

4.3.2 Acúmulo total de massa seca....................................................................... 109

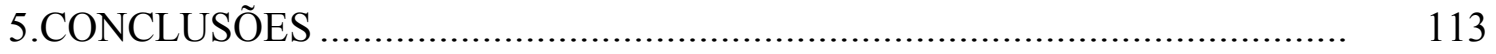

REFERÊNCIAS BIBLIOGRÁFICAS ............................................................ 114 


\section{CARACTERÍSTICAS ESTRUTURAIS DO DOSSEL FORRAGEIRO, VALOR NUTRITIVO E PRODUÇÃO DE FORRAGEM EM PASTOS

\author{
DE CAPIM-MOMBAÇA SUBMETIDOS A REGIMES DE
} \\ LOTAÇÃO INTERMITENTE}

Autora: ADRIANA AMARAL DE OLIVEIRA BUENO

Orientador: Prof. Dr. SILA CARNEIRO DA SILVA

\section{RESUMO}

A produção e o valor nutritivo da forragem em pastagens são função de variações em composição botânica e morfológica do pasto que, por sua vez, são conseqüência do controle e monitoramento da condição e estrutura do dossel forrageiro. Dentro desse contexto, o objetivo deste experimento foi avaliar os efeitos de combinações entre intensidade e intervalo entre pastejos sobre a produção, composição botânica e morfológica e valor nutritivo da forragem ao longo de uma estação de crescimento inteira (janeiro/01 a fevereiro/02) em pastos de capim-Mombaça pastejados por bovinos. Adicionalmente, visou identificar estratégias de manejo do pastejo que permitissem obter alta produtividade e utilização de forragem, mantendo a estrutura do pasto dentro de limites aceitáveis de uso e garantindo, assim, alimento em quantidade e qualidade para os animais. O experimento foi realizado na Universidade Federal de São Carlos, Araras, SP, entre 8 de janeiro de 2001 e 23 de fevereiro de 2002. Os tratamentos corresponderam a combinações entre duas intensidades (30 e $50 \mathrm{~cm}$ de resíduo) e dois intervalos de pastejo (pastejo iniciado com 95 e $100 \%$ de interceptação de luz do dossel forrageiro - IL) e foram alocados às unidades experimentais conforme delineamento de 
blocos completos casualizados, em arranjo fatorial 2 x 2, com 4 repetições. Foram avaliadas as seguintes variáveis-resposta ao longo de todos os ciclos de pastejo: teores de matéria mineral, proteína bruta, fibra insolúvel em detergente neutro e ácido, lignina e digestibilidade in vitro da matéria orgânica. De forma geral, os pastos acumularam forragem de forma contínua durante a rebrotação, sendo a maior produtividade obtida para o tratamento 30/95 (26.910 kg MS.ha ${ }^{-1}$ ), seguida do 30/100, 50/100 e 50/95 (24.900, 20.280 e $17.910 \mathrm{~kg} \mathrm{MS.ha}{ }^{-1}$, respectivamente). No entanto, a partir de determinada fase de rebrotação o acúmulo foi proveniente de hastes e material morto, componentes que, em altas proporções, são indesejáveis para a alimentação animal e eficiência do pastejo. Pastos com pastejos iniciados com 100\% IL do dossel apresentaram maiores proporções de hastes $(14,7 \times 8,0 \%)$ e material morto $(9,7 \times 6,5 \%)$ na forragem em pré-pastejo, o que resultou em redução dos teores de proteína $(9,0 \mathrm{x}$ $11,2 \%)$ e da digestibilidade $(55,0 \times 58,1 \%)$ comparativamente àqueles de $95 \%$ IL do dossel. Adicionalmente, quando períodos de descanso mais longos (100\% IL) foram associados com o resíduo de $30 \mathrm{~cm}$, a presença de hastes e material morto impediu que o resíduo planejado fosse mantido ao longo do ano (50,7 cm ao final do inverno). Pastejos mais freqüentes, propiciados pelo pastejo iniciado com $95 \%$ IL do dossel, permitiram também um controle mais efetivo do florescimento das plantas, especialmente quando associados ao resíduo de $30 \mathrm{~cm}$. Conclui-se que o manejo do pastejo em pastos de capim-Mombaça submetidos à lotação intermitente deve ser iniciado com 95 \% IL do dossel (90 cm de altura em pré-pastejo) e terminado quando o resíduo atingir $30 \mathrm{~cm}$, sendo o período de descanso função da taxa de acúmulo de massa seca dos pastos. 


\section{CANOPY STRUCTURAL CHARACTERISTICS, NUTRITIVE VALUE AND \\ HERBAGE PRODUCTION OF MOMBAÇA GRASS PASTURES \\ SUBMMITED TO INTERMITENT DEFOLIATION REGIMES}

Author: ADRIANA AMARAL DE OLIVEIRA BUENO

Adviser: Prof. Dr. SILA CARNEIRO DA SILVA

\section{SUMMARY}

Forage yield and nutritive value in pastures are a function of variations in sward botanical and morphological composition, which result from monitoring and controlling sward condition and structure. Against this background, the objective of this experiment was to evaluate the effects of combinations of grazing intensity and frequency on dry matter production and botanical and morphological composition of the herbage in Mombaça grass patures grazed by dairy cattle for 411 days (January/01 to February/02). Additionally, it aimed at identifying grazing management strategies that would allow for high pasture productivity and herbage utilization, keeping sward structure within acceptable limits of use and ensuring adequate supply of good quality feed to animals. The experiment was carried out at Universidade Federal de São Carlos, Araras, SP, from 8 January 2001 to 23 February 2002. Treatments corresponded to combinations between two grazing intensities (30 and $50 \mathrm{~cm}$ post-grazing height) and two grazing intervals (grazing initiated at 95 and 100\% canopy light interception - LI) and were allocated to experimental units according to a complete block design, in a $2 \times 2$ factorial arrangement, with 4 replicates. The following responses were measured in all grazing cycles: forage concentration of total ash, crude protein, neutral as well as acid detergent 
fiber and lignin content, and in vitro organic matter digestibility. In general, pastures accumulated herbage continuously during regrowth, with the highest productivity recorded for the 30/95 treatment $\left(26,910 \mathrm{~kg} \mathrm{DM}^{-h^{-1}}\right.$ ), followed by 30/100, 50/100 and 50/95 (24,900; 20,280 and 17,910 kg DM.ha ${ }^{-1}$, respectively). However, from a certain point during regrowth herbage accumulation was a consequence of stem elongation and dead material accumulation, components that, in high proportions, are undesirable for feeding animals and grazing efficiency. When grazing started at 100\% canopy light interception there was a higher proportion of stem $(14.7 \times 8.0 \%)$ and dead material $(9.7$ $\mathrm{x} 6.5 \%$ ) in the pre-grazing herbage mass than when it started at $95 \% \mathrm{LI}$, which caused reduction in crude protein content $(9.0 \times 11.2 \%)$ and organic matter digestibility of the herbage $(55.0 \times 58.1 \%)$. When longer grazing intervals $(100 \% \mathrm{LI})$ were associated with the $30 \mathrm{~cm}$ post-grazing height, the post-grazing target for sward height could not be maintained throughout the year due to the accumulation of stem and dead material at the base of the sward $(50.7 \mathrm{~cm}$ in late winter). More frequent grazings, related to the $95 \%$ canopy light interception defoliation regime, allowed for an effective control of reproductive growth of plants, particularly when associated with the post-grazing height of $30 \mathrm{~cm}$. It was concluded that grazing management of Mombaça grass pastures submitted to intermittent stocking must be initiated at 95\% canopy light interception (90 cm pre-grazing height) and finished when pastures are grazed down to $30 \mathrm{~cm}$, with grazing intervals being a function of sward herbage accumulation rates. 


\section{INTRODUÇÃO}

No contexto da pecuária mundial, o principal foco dos pesquisadores tem sido sistemas de produção utilizando-se de pastagens como o principal recurso forrageiro, pois esta é a alternativa mais econômica na alimentação de ruminantes. Para tanto, a otimização de sistemas de pastejo não pode ser voltada somente para a maximização da forragem produzida ou ingerida pelos animais. São também necessários cuidados com relação a características da planta como: perenidade, rebrotação rápida após desfolhação, tolerância à presença do animal, valor nutritivo adequado e, principalmente, qualidade.

O conceito de "valor nutritivo" refere-se à composição química da forragem e sua digestibilidade. Já a qualidade de uma planta forrageira corresponde a sua capacidade em gerar desempenho animal, ou seja, à associação entre sua composição química, digestibilidade, consumo voluntário e interação de fatores hereditários e ambientais (Mott, 1970; Moore, 1994).

Hassan et al. (1990) e Singh (1995) realizaram estudos com diversas gramíneas forrageiras, dentre elas o Panicum maximum Jacq, que apresentou aumento na produção quando ocorria um aumento no intervalo entre cortes, mas seguido, contudo, de queda na qualidade. Isso porque a qualidade da pastagem está diretamente associada à forma com que o alimento está disponível ao animal, ou seja, fatores relacionados à estrutura do dossel. As forragens tropicais possuem habilidade natural de acumular mais constituintes de parede celular que as espécies de clima temperado (Moore e Mott, 1973). Sendo assim, o processo de desfolhação da pastagem se torna muito complexo, pois a produção animal obtida é influenciada pela interação ambiente:solo:planta:animal. Diferenças no desempenho de animais em pastejo em pastagens tropicais podem 
favorecer melhorias nos sistemas de manejo utilizados se forem empregadas de forma planejada e orientada com base em dados consistentes e confiáveis de quantidade e composição química da forragem consumida. Quando os animais pastejam, as folhas superiores são as primeiras a serem consumidas, seguidas das folhas próximas ao caule $\mathrm{e}$, finalmente, se forçados por racionamento estrito, dos caules praticamente sem folhas (Stobbs, 1975). Nessa situação, o comportamento entre e dentro das espécies tende a diferir, assumindo maior importância quanto mais intensivos forem os sistemas de produção baseados em pastagens. Esse comportamento necessita ser melhor compreendido para orientação na tomada de decisões acerca do manejo do pastejo, visando melhor aproveitamento da forragem acumulada. Por isso é de grande importância o conhecimento dos teores de proteína bruta, fibra, matéria seca e digestibilidade quando se iniciam avaliações de uma planta promissora (Mott, 1970; Nunes et al, 1985).

Dentro desse contexto, este estudo avaliou os efeitos de combinações entre intensidade e intervalo entre pastejos sobre a produção, composição morfológica e valor nutritivo da forragem em pastos de capim-Mombaça (Panicum maximum Jacq. cv Mombaça) pastejados por bovinos, visando identificar estratégias de manejo do pastejo que permitissem obter alta produtividade e utilização de forragem, mantendo a estrutura do dossel forrageiro dentro de limites aceitáveis de uso e assegurando seu valor nutritivo. 


\section{REVISÃO DE LITERATURA}

\subsection{O capim-Mombaça}

Segundo Savidan (1990), o cultivar Mombaça foi lançado pela EMBRAPACentro Nacional de Pesquisa de Gado de Corte (CNPGC), de Campo Grande, MS, em 1993. Esse cultivar foi classificado como BRA-006645 e coletado próximo de Korongue, na Tanzânia, em 1967. Trata-se de uma planta ereta e cespitosa com altura média de 1,65 m. As folhas são quebradiças, com largura média de 3,0 $\mathrm{cm}$ e sem cerosidade. As lâminas apresentam poucos pêlos (duros e curtos), principalmente na face superior. As bainhas são glabras. Os colmos são levemente arroxeados. A inflorescência é uma panícula com ramificações primárias longas e secundárias longas apenas na base. As espiguetas são glabras, uniformemente distribuídas, e arroxeadas em aproximadamente $1 / 3$ da superfície externa. $O$ verticilo normalmente apresenta micropilosidade. Apresenta alta produtividade de forragem 165,3 t.ha ${ }^{-1}$.ano ${ }^{-1}$ de massa verde e 32,9 t.ha ${ }^{-1}$.ano ${ }^{-1}$ de massa foliar seca. Apresenta alta porcentagem de folhas (cerca de 80\%), sendo que no inverno atinge cerca de $87 \%$ de folhas. Com baixas doses de fertilizantes pode produzir até $75 \%$ da produção obtida com uso pleno desse insumo. Apresenta em torno de $10 \%$ da produção anual durante a seca. Os teores de proteína bruta nas folhas e colmos giram em torno de 13 e 10\%, respectivamente, e a produção de sementes ocorre entre os meses de abril e junho. Para gramíneas do gênero Panicum, valores de parede celular inferiores a $55 \%$ são raramente observados, superiores a $65 \%$ são comuns em rebrotações e, em estádios avançados de maturação, situam-se entre 75 e 80\% (Euclides, 1995). 
O capim-Mombaça é uma planta com um potencial de produção condizente com taxas de lotação de 1,8 UA.ha ${ }^{-1}$ a 5,2 UA.ha ${ }^{-1}$, ganhando cerca de $720 \mathrm{~kg} \mathrm{PV} \cdot \mathrm{ha}^{-1} \cdot$ ano $^{-1}$ (IAPAR - Paranavaí) (Jank , 1994) e pode atingir, segundo Corsi \& Santos (1995), de 12 a 15 UA.ha $a^{-1} \cdot$ ano $^{-1}$ no verão e 3 a 4 UA.ha ${ }^{-1} \cdot$ ano $^{-1}$ no inverno, proporcionando um ganho de 1600 a $2000 \mathrm{~kg} \mathrm{PV} \cdot \mathrm{ha}^{-1}$.ano ${ }^{-1}$. Barbosa (1996) obteve 7,2 t MS.ha ${ }^{-1}$ com 11,1\% de proteína bruta no verão e $2,4 \mathrm{t} \mathrm{MS} \cdot \mathrm{ha}^{-1}$ com $10,4 \%$ de proteína bruta no inverno. A produção de forragem obtida por Machado et al. (1997) foi de 20 a $21 \mathrm{t} \mathrm{MS} \cdot \mathrm{ha}^{-1} \cdot \mathrm{ano}^{-1}$, sendo que as parcelas cortadas mais intensamente proporcionaram as produções mais elevadas. Santos (1997) afirmou que, para as épocas de maior disponibilidade de fatores de crescimento, um período de descanso inferior a 28 dias seria o mais indicado para o capim-Mombaça.

\subsection{Plantas Forrageiras em Pastagens}

O manejo embasado nas características da planta e nas condições de ambiente tem resultado em grande desenvolvimento do setor pecuário em alguns países de clima temperado. Centros de pesquisa tidos como desenvolvidos nesses países têm realizado estudos dessa natureza há mais de 50 anos, sendo a marca registrada da pesquisa em pecuária. Nos países de clima tropical, os estudos são basicamente fundamentados em intervalos de descanso, taxas de lotação e/ou intensidade de corte/pastejo fixos, raramente respeitando a ecofisiologia da planta e sem controle algum de características estruturais do dossel forrageiro (e. g. índice de área foliar), variáveis-chave para o correto manejo da desfolhação e uso da forragem produzida. Como conseqüência, o desempenho das pastagens é muito variável e inconsistente, resultando num elevado grau de insatisfação por parte dos produtores e técnicos do setor. A necessidade de intensificar o uso das pastagens direciona os pesquisadores a dar nova ênfase e enfoque aos estudos com plantas forrageiras tropicais.

Em estudos de Brougham (1955) foi determinada a natureza da curva de rebrotação de azevém perene (Lolium perene L.) e trevo branco (Trifolium repens L.) e vermelho (Trifolium repens L.) em pastos submetidos a desfolhações sucessivas. A 
curva apresenta três fases distintas. Na primeira fase, as taxas de acúmulo líquido de forragem aumentam exponencialmente com o tempo. Essa fase é altamente influenciada por reservas orgânicas das plantas, disponibilidade de fatores de crescimento e área residual de folhas (Brougham, 1957). A segunda fase apresenta taxas de acúmulo líquido constantes. Nessa fase, o processo de competição inter e intra-específica adquire caráter mais relevante, principalmente quando aproxima-se da completa interceptação da luz incidente. $\mathrm{Na}$ terceira fase, inicia-se a queda das taxas de acúmulo líquido, causada pela redução na taxa de crescimento e pelo aumento na senescência de folhas, provocado pelo sombreamento (Hodgson et al., 1981).

Brougham (1955) verificou a necessidade de se estudar a influência da intensidade em relação à freqüência de desfolhação após observar que a intensidade de corte utilizada alterava a fase inicial da curva de acúmulo. Brougham (1956) desenvolveu um estudo para determinação da influência da intensidade de desfolhação sobre as taxas subsequentes de acúmulo de forragem e interceptação de luz em campos de azevém perene consorciado com trevo branco sob regime de corte. $\mathrm{O}$ autor verificou que as taxas de acúmulo do azevém estavam relacionadas à área foliar e à porcentagem de luz interceptada pelo dossel. O acúmulo atingia uma taxa máxima constante que era mantida enquanto existia área foliar suficiente para interceptar quase toda luz. Outra conclusão foi que uma maior intensidade de desfolhação exigia um tempo mais prolongado de recuperação, pois a primeira fase de rebrotação estendia-se por um período maior. Contudo, a produção máxima atingida na curva de crescimento era a mesma de campos submetidos a cortes menos intensos.

Após constatação da interação entre intensidade e freqüência de desfolhação sobre o manejo das plantas forrageiras, Brougham (1959) passou a estudar o efeito da combinação entre freqüência e intensidade em áreas pastejadas. Nesse estudo, o autor confirmou também a necessidade de manejar áreas sob pastejo através da combinação entre intensidade e freqüência de desfolhação, ou seja, pastejos intensos necessitavam de um período de rebrotação mais longo (menor freqüência), enquanto pastejos lenientes necessitam de períodos de rebrotação mais curtos (maior freqüência). 
Wilson \& Mc Guire (1961) e Donald (1961), citados por Marshall (1987), quantificaram a luz que era interceptada pelo dossel forrageiro de azevém perene, mencionada por Brougham (1960). Os autores encontraram redução na produção total dos pastos quando os mesmos eram desfolhados com menos de $95 \%$ de interceptação luminosa (IL).

Quando o dossel atinge 95\% de IL as folhas inferiores passam a ser sombreadas. A redução ou a ausência de luz numa folha induz uma diminuição na sua atividade fotossintética, e essa passa da condição de fonte de fotoassimilados para a condição de dreno. A partir desse ponto, as taxas de fotossíntese e respiração no dossel tornam-se muito próximas. Esse é considerado o índice de área foliar ótimo, onde a taxa de acúmulo de massa seca do pasto atinge um máximo. Aumentos subsequentes em índice de área foliar reduzem a taxa de acúmulo do pasto em função do aumento nas taxas de respiração, resultantes de um aumento na quantidade de tecidos sem função fotossintética (senescentes) (Donald, 1961; citado por Marshall, 1987). Quando isso ocorre, há um declínio na proporção de folhas e o maior acúmulo passa a ser proveniente de hastes. A planta passa do estádio vegetativo para a maturidade e, ao mesmo tempo, os teores dos componentes de parede celular aumentam (Blaser, 1988). Esse comportamento foi validado por Korte (1982) em estudos realizados com azevém perene, onde foram avaliadas estratégias de manejo fundamentadas em combinações entre freqüências e intensidades de pastejo. Os intervalos entre desfolhações foram baseados na interceptação luminosa e as intensidades de pastejo baseadas em índice de área foliar residual. $\mathrm{O}$ autor concluiu que a utilização da pastagem quando o dossel atingiu 95\% de IL era a estratégia que permitia a otimização da produção de forragem. Para plantas de clima tropical estudos baseados em interceptação luminosa para controle e manejo do pastejo são praticamente inexistentes na literatura.

\subsection{Composição morfológica e valor nutritivo da forragem}

As condições climáticas favoráveis ao acúmulo de massa seca, idade e o desenvolvimento morfológico fazem com que as plantas forrageiras sofram alterações 
nos atributos produtivos e nutricionais (Ramos, 1997). A composição química das plantas forrageiras é um dos parâmetros utilizados para medir seu valor nutritivo e, dentre outros fatores, é afetada pela espécie ou cultivar, idade dos tecidos e fertilidade do solo (Coward-Lord, 1972). O baixo valor nutritivo das plantas forrageiras tropicais é freqüentemente mencionado na literatura. Esse valor nutritivo é, muitas vezes, associado ao reduzido teor de proteína e de minerais e ao alto conteúdo de fibras que ocorre geralmente em pastagens maduras ou que não foram manejadas adequadamente.

Pedreira \& Mattos (1982) afirmaram que variações nas taxas mensais de acúmulo de massa seca podem provocar contínuas alterações qualitativas durante o ano ou até durante uma estação do ano, mesmo quando o capim é utilizado com intervalos iguais entre pastejos sucessivos, como é o caso do sistema de lotação intermitente utilizado tradicionalmente. Em uma avaliação de um sistema de pastejo intensivo em pastagens adubadas de capim-Tobiatã, Sarmento et al. (1997) relataram que face à diferença entre os teores de proteína da folha e do caule, seria importante privilegiar práticas de manejo do pastejo que elevassem a proporção de folhas na forragem ingerida, melhorando seu valor nutritivo.

A importância da relação folha:haste como fator importante para a tomada de decisão acerca do manejo do pastejo foi constatada por Pinto et al. (1994a). Os autores observaram diminuição na relação folha:haste do capim-Guiné (Panicum maximum Jacq.) à medida que a idade de rebrotação aumentava. Nas idades de 14, 28, 4256 e 70 dias obtiveram as relações de 1,$3 ; 1,2 ; 1,0 ; 0,7$ e 0,5 , respectivamente.

Corsi (1995) afirmou que a presença da haste determina o declínio acentuado da digestibilidade de gramíneas tropicais mas, por outro lado, parece ser imprescindível para manter elevada produtividade. Assim, para manter o elevado potencial produtivo das plantas forrageiras tropicais seria necessário aproveitar a variabilidade genética quanto à digestibilidade das hastes, situação essa em que avaliações cuidadosas sobre seu comportamento quantitativo e qualitativo no decorrer do desenvolvimento da planta adquirem importância significativa.

As frações fibrosa e protéica são as mais comumente analisadas, pois com o aumento da maturidade da planta aumenta a concentração de constituintes da parede 
celular nos tecidos vegetais. As bainhas das folhas alcançam uma maior porcentagem de fibra bruta e lignina, folhas velhas senescem e perdem água, hastes alongam e se tornam pouco suculentas. Com o aumento da produção de massa seca ocorre declínio na proporção de folhas e no teor de proteína bruta da forragem. A deficiência protéica também limita a produção animal, seja porque a forragem disponível pode conter proteína insuficiente ou a concentração de proteína bruta é inferior ao nível mínimo crítico $(7 \%)$ para o bom funcionamento do rúmen. Ocorre, então, uma diminuição da atividade dos microrganismos do rúmen, das taxas de digestão e de passagem do alimento e conseqüentemente, no consumo voluntário (Euclides, 1995).

A fibra não é uma fração uniforme ou um composto puro, de composição definida. Ela é formada pelos componentes de parede celular e estimada pela análise de fibra insolúvel em detergente neutro (FDN). Embora a parede celular possa ser digerida pelos microrganismos do rúmen, na prática isso não ocorre por completo. Dessa forma, a fibra é usada como índice qualitativo negativo nas avaliações de forragens (Euclides, 1995).

Segundo Balsalobre (2002), a presença de hastes pode reduzir a eficiência do sistema limitando a capacidade de colheita da forragem pelo animal e reduzindo seu valor alimentar (qualidade). Cecato et al. (1985) mencionaram a altura de corte ou pastejo como sendo um dos fatores que influencia a composição bromatológica da planta, uma vez que cortes ou pastejos mais baixos proporcionaram colheita de materiais fibrosos e com menor teor de proteína bruta.

Contudo, animais em pastejo selecionam o que consomem, de forma que o valor nutritivo da forragem consumida é, invariavelmente, superior àquele da forragem em oferta (Hodgson, 1990), fato este que revela a importância de assegurar ao animal a oportunidade de seleção. Os animais têm preferência por folhas e partes novas da planta. Em geral, essas partes apresentam melhor valor nutritivo e aparecem em maior proporção nos estratos superiores do dossel forrageiro. Como a proporção de folhas do resíduo pós-pastejo é inferior àquela da massa de forragem em pré-pastejo, há um aumento na dificuldade de colheita de folhas pelos animais à medida que os estratos superiores vão sendo eliminados pelo pastejo. Uma redução na quantidade e na 
qualidade das folhas à medida que a forragem é consumida acentua a queda no valor nutritivo (Hodgson, 1990). Segundo Veiga et al. (1985), a seletividade de pastejo em capim-elefante melhorou a composição química da forragem ingerida, tendo em vista a grande diferença de valor nutritivo entre as partes da planta (folhas e hastes). Além do aspecto qualitativo, o uso do capim-elefante de porte alto, em pastejo direto, tem restrições de manejo relacionadas com o seu hábito de crescimento. Nesse estudo, os autores observaram que os teores de proteína bruta das folhas e das hastes foram afetados pela pressão e pelo ciclo de pastejo. Dados gerados por Britto et al. (1970) mostraram que o capim-elefante com 45 dias de idade apresentava de 30 a $43 \%$ de fibra insolúvel em detergente ácido (FDA), demonstrando que essa fração poderia limitar o consumo de forragem pelo animal, o nível de energia de sua dieta e, conseqüentemente, sua produção de leite.

A produção animal está diretamente associada ao consumo diário de massa seca digestível quando proteína, minerais e outros fatores nutricionais são adequados. Para obtenção de altos níveis de produção por animal a partir de uma determinada espécie forrageira, seu estádio de crescimento é determinante da relação entre morfologia da planta, estrutura do dossel forrageiro e desempenho animal. Altos níveis de produção por animal estão diretamente associados à proporção de folhas, teor de proteína e consumo de massa seca digestível (Blaser, 1988). Uma alta eficiência de conversão alimentar pode ser restringida por reduções em valor nutritivo da planta forrageira.

Para caracterizar a forragem disponível aos animais em pastejo, o fracionamento da forragem acumulada em estratos e sua separação em componentes como folha, haste e material morto descreve melhor as alterações morfológicas e fisiológicas decorrentes do crescimento e desenvolvimento das plantas forrageiras (Ramos, 1997). Além disso, as decisões de manejo, a eficiência no aproveitamento da planta forrageira e a conversão em produto animal mantém estreita relação com esses parâmetros. Variações na condição e estrutura do dossel forrageiro e disponibilidade de forragem influenciam o animal através de seus efeitos sobre a quantidade e o valor nutritivo da forragem consumida. De acordo com Corsi (1988), o elevado potencial de produção de massa seca por unidade de área das plantas forrageiras tropicais e a homogeneidade da idade 
cronológica dos perfilhos fazem com que essas percam qualidade muito rapidamente com a maturidade em função de alterações em sua composição morfológica (relação haste:folha), o que acarreta um menor consumo de massa seca e decréscimo de seu valor nutritivo quando colhidas de maneira inadequada.

Para assegurar alto valor nutritivo sugere-se que apenas os estratos superiores sejam pastejados por animais de maior potencial de produção, sendo o restante da forragem destinado a animais de menor exigência nutricional (Hodgson, 1990). Na Virgínia, EUA, com pastejo rotacionado, vacas leiteiras, como primeiras pastejadoras, consumiram cerca de $50 \%$ da disponibilidade de forragem e produziram 25 , 54 , e $49 \%$ mais leite do que aquelas que pastejaram por último (animais seguidores) durante 3 anos (Bryant et al., 1961 e Blaser et al., 1969). O melhor desempenho naquelas condições foi devido a um consumo de matéria seca $17 \%$ maior em relação aos animais seguidores.

Entretanto, a determinação da melhor estratégia de colheita da forragem depende do conhecimento de cada espécie forrageira utilizada para pastejo. O subsídio oferecido pela literatura é baseado em informações esparsas e, na maioria das vezes, obtidas sem a presença de animais em pastejo como parte integrante da proposta experimental. Dentre as informações existentes encontra-se o trabalho de Favoretto \& Furtado (1978), que conduziram um estudo sobre o efeito do corte de capim-Colonião em quatro alturas sobre a produção e composição químico-bromatológica da forragem. As plantas eram cortadas conforme atingiam 50,60,70 ou $80 \mathrm{~cm}$. Os teores de proteína bruta foram considerados adequados à alimentação animal $(13,6 \%)$ quando as plantas eram cortadas com $50 \mathrm{~cm}$ de altura. Em relação à composição químico-bromatológica e às características fisiológicas e de produção, os cortes com 60 e $80 \mathrm{~cm}$ de altura média foram os que apresentaram os melhores resultados.

Pedreira \& Silveira (1972) observaram uma variação acentuada na composição do capim-Colonião a partir da primeira amostra colhida aos 26 dias de desenvolvimento. De um modo geral, a tendência para as frações matéria seca, proteína e fibra bruta foram semelhantes àquela já observada para outras espécies de gramíneas forrageiras. Em Porto Rico, Vicente-Chandler et al. (1964) estudaram o efeito do intervalo entre cortes sobre a produção e características bromatológicas dos capins Elefante (Pennisetum 
purpureum Schum), Colonião (Panicum maximum Jacq.) e Pará (Brachiaria mutica Stapf). Os resultados mostraram uma elevação na produção total de massa seca anual à medida que se aumentava o intervalo entre cortes de 40 para 90 dias. Entretanto, os valores encontrados para a relação folha:haste e porcentagem de proteína bruta decresceram com o aumento no intervalo entre cortes, e foram de 1,70; 1,22; e 0,56, bem como de 9,0; 7,0 e 5,6\% para tratamentos correspondentes aos cortes realizados com 40, 60 e 90 dias, respectivamente.

Gerdes et al. (1999), avaliando o valor nutritivo das gramíneas forrageiras capimMarandu (Brachiaria brizantha Stapf. cv. Marandu), capim-Setária (Setaria sphacelata (Schum.) Moss var.sericea (Stapf.) cv. Kanzugula) e capim-Tanzânia (Panicum maximum Jacq. cv. Tanzânia-1) nas estações do ano, observaram grandes diferenças nos teores de proteína bruta e FDN de lâminas foliares e hastes do capim-Tanzânia, que apresentaram, respectivamente, 15,3 e 7,5\% de PB e 73,8 e 77,8\% de FDN durante a primavera. Para a digestibilidade in vitro da matéria seca (DIVMS) houve uma pequena redução dos valores apresentados para hastes e lâminas foliares sendo, 55,7\% e 56,9\% respectivamente.

Rego et al. (2001) conduziram um trabalho para avaliar os teores de PB, FDN e FDA de pastos de capim-Tanzânia mantidos em quatro alturas do dossel forrageiro (24 a 26, 43 a 45, 52 a 62, 73 a $78 \mathrm{~cm}$ ) e concluíram que o aumento na altura do dossel resultou em forragem com menores teores de PB e maiores teores de FDN e FDA.

Gomes (2001), ao estudar os efeitos da oferta de forragem (4, 8 e 12\%) e períodos de ocupação (1 e 3 dias) sobre o valor nutritivo do capim-Mombaça, observaram que os teores de proteína bruta diminuíram linearmente com o aumento na oferta de forragem, seguidos de um aumento na quantidade de parede celular com a diminuição da intensidade de pastejo durante os períodos de verão e de inverno.

Machado et al. (1998), avaliando a composição química de cultivares e acessos de Panicum maximum Jacq., dentre eles o capim-Mombaça, nas alturas de 20 e $40 \mathrm{~cm}$, verificaram que não houve respostas à altura de corte em qualquer um dos acessos e cultivares. O capim-Mombaça, em intervalos de corte de 35 dias, se destacou com teor médio de PB no verão de 12,9\%. No inverno, em intervalos de 70 dias, seu teor médio 
de PB foi de 13,3\%, indicando que o teor nesse período foi maior devido às condições climáticas desfavoráveis que proporcionaram à planta um menor desenvolvimento de colmos e, consequentemente, aumento no valor protéico da forragem devido à maior presença de folhas. Pelo mesmo motivo os valores de FDN e FDA foram maiores no verão e mais baixos no inverno, com o capim-Mombaça apresentando valores médios de $73,4 \%$ de FDN e $43,5 \%$ de FDA no verão e $69,6 \%$ de FDN e 40,6\% de FDA no inverno. Para valores de digestibilidade os autores não encontraram diferenças ao longo do ano, sendo $64,6 \%$ no verão e $64,9 \%$ no inverno.

Avaliando o capim-Mombaça sob pastejo, Herling et al. (1998 a) testaram dois períodos de descanso (35 e 42 dias) e três intensidades de pastejo (1000, 2000 e $3000 \mathrm{~kg}$ MS residual.ha ${ }^{-1}$ ). Os autores concluíram que o período de descanso deveria ser ajustado especificamente para cada época do ano e que 42 dias era um tempo de descanso muito longo, pois resultou em aumento na quantidade de material fibroso e nas perdas por pastejo.

Costa et al. (2000), avaliando a produção estacional do capim-Mombaça em diferentes épocas de aplicação e doses de $\mathrm{N}$, verificaram que a produção de massa seca e de proteína bruta foram equilibradas durante o verão e o inverno, sendo os teores de PB de $9,8 \%$ no verão e $8,7 \%$ no inverno. A diferenciação foi justificada pela presença de folhas velhas e senescentes no material colhido durante o inverno, além da idade mais avançada das plantas e do aumento na proporção de hastes.

Braga (2001), avaliando a resposta do capim-Mombaça a doses de nitrogênio e intervalo entre cortes, observou alterações de valor nutritivo quando o intervalo entre cortes foi ampliado de 28 para 42 dias no verão e de 56 para 84 dias no inverno. Os teores médios de PB foram de 11,4 e 9,2\% no verão e 10,4 e 9,5\% no inverno respectivamente. Os teores médios de FDN foram semelhantes $(75,3 \%)$ para os dois intervalos entre cortes estudados durante o período de verão. Para o inverno, a média foi de 76,5 e 72,4\% para os intervalos de 56 e 84 dias, respectivamente. Em relação aos teores de FDA, as médias registradas no verão foram de 40,4\% (28 dias) e 43\% (42 dias) e no inverno foram de $39,1 \%$ para ambos os intervalos. O intervalo entre cortes mais curto apresentou uma média de 56,3\% de DIVMS, seguido de 53,1\% para o intervalo 
mais longo durante o período de verão. No inverno houve uma queda da digestibilidade para cerca de $50 \%$ nos dois intervalos avaliados. No verão não houve variação nos teores de FDN, apesar da queda nos teores de PB. Já no inverno, o valore de FDN foi mais elevado para o menor período de descanso e esteve associado ao maior teor de PB.

Portanto, o intervalo entre cortes em gramíneas forrageiras afeta diretamente a produção, o valor nutritivo, o potencial de rebrotação, a composição botânica e morfológica e a sobrevivência das espécies. Em geral, um extenso período entre cortes tem com conseqüência um aumento no teor de matéria seca, fibra, lignina e um decréscimo na relação folha:haste, teor de proteína bruta e digestibilidade, que resultam em um declínio do consumo (Crowder \& Chheda, 1992).

Face à reduzida disponibilidade de dados na literatura, ainda não é possível definir a melhor estratégia de pastejo para plantas tropicais. Sendo assim, estudos básicos como o de Korte (1982) são necessários para que se possa inferir sobre o manejo mais indicado do pastejo, sem prejudicar a qualidade e a disponibilidade de forragem, e assegurar a longevidade da pastagem. Dentro desse contexto, o presente trabalho teve por objetivo estudar a manipulação das condições de pós e pré-pastejo do capimMombaça submetido a regimes de lotação intermitente sobre o acúmulo, composição morfológica e valor nutritivo da forragem produzida. 


\section{MATERIAL E MÉTODOS}

\subsection{Material}

\subsubsection{Espécie vegetal, local e período do experimento}

O experimento foi realizado com o capim da espécie Panicum maximum Jacq. cv. Mombaça pastejado por vacas em lactação da Raça Holandesa (agentes desfolhadores) com peso vivo médio de $570 \mathrm{~kg}$. A área utilizada faz parte do Sistema de Produção de Leite do Departamento de Biotecnologia Vegetal, do Centro de Ciências Agrárias da Universidade Federal de São Carlos, situada no município de Araras, SP (Figura 1). As coordenadas geográficas aproximadas do local são $22^{\circ} 18^{\prime}$ de latitude sul, $47^{\circ} 23$ 'de longitude oeste e $611 \mathrm{~m}$ de altitude. As áreas de pastagem foram formadas em 1998 e em 2000 passaram por processo de drenagem já que eram áreas facilmente alagáveis. A fase experimental correspondeu ao período de 8 de janeiro de 2001 a 23 de fevereiro de 2002, com duração de 411 dias.

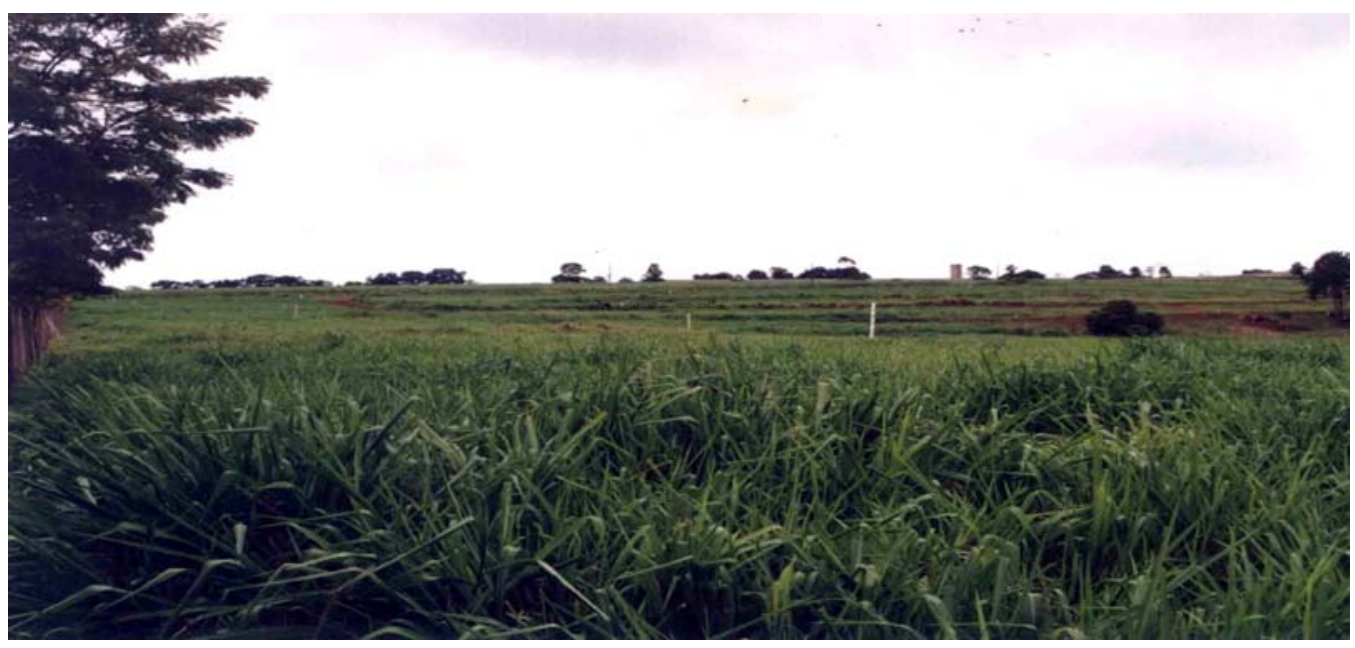

Figura 1 - Vista geral da área experimental 


\subsubsection{Dados climáticos}

Os dados climáticos referentes ao período experimental e as médias mensais dos últimos 30 anos são apresentadas nas Figuras 2 e 3. Esses dados foram obtidos no Posto Meteorológico da Universidade Federal de São Carlos, campus de Araras, distante cerca de 500 metros da área experimental. Na Figura 4 é apresentado o balanço hídrico correspondente aos meses de realização do experimento.

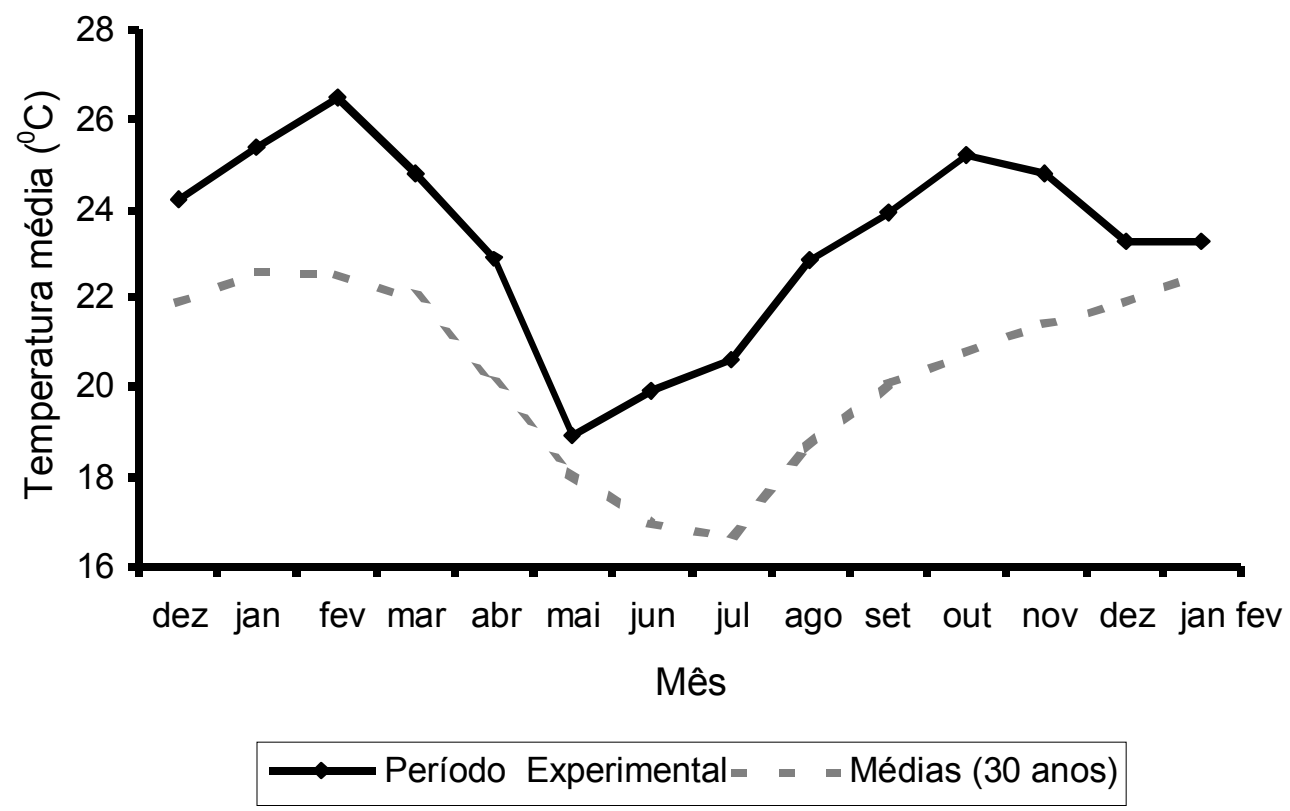

Figura 2 - Distribuição das temperaturas médias durante o período experimental (jan/2001 - fev/2002) e nos últimos 30 anos (jan/1971 - jan/2001) 


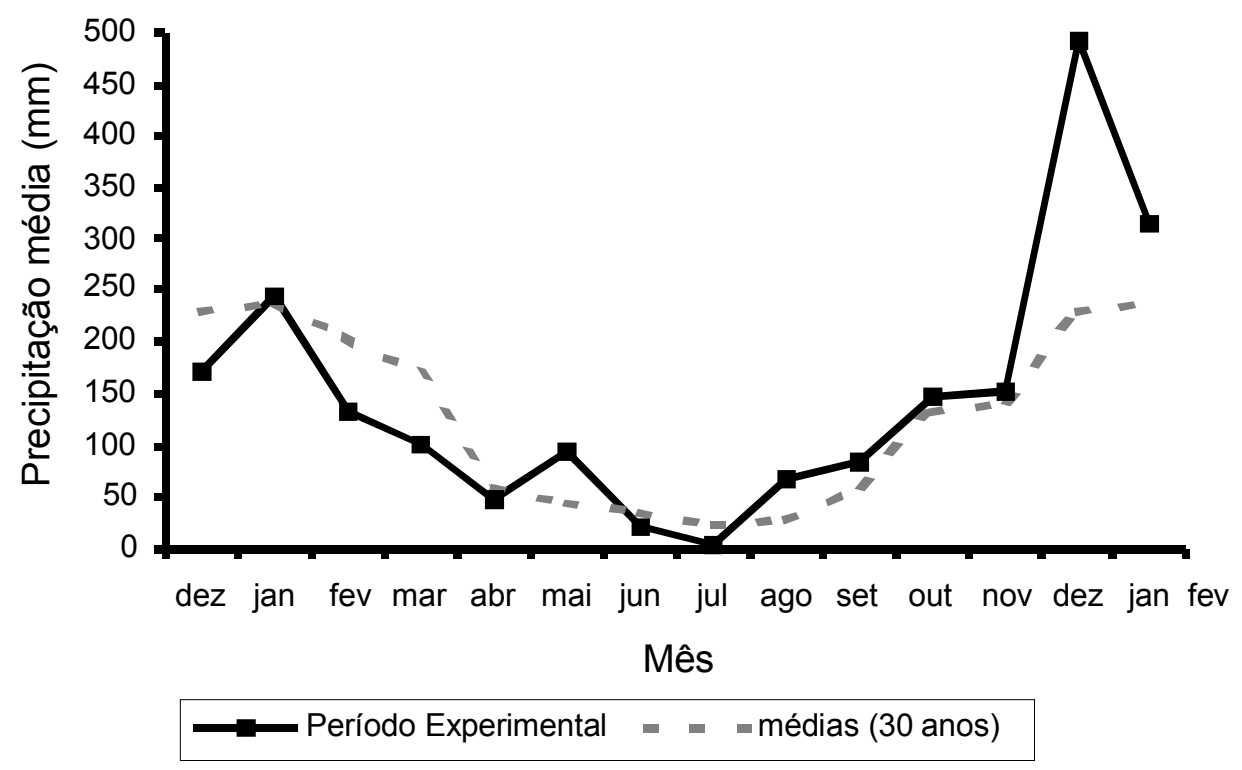

Figura 3 - Distribuição da precipitação (mm) durante o período experimental (jan/2001fev/2002) e nos últimos 30 anos (jan/1971 - jan/2001)

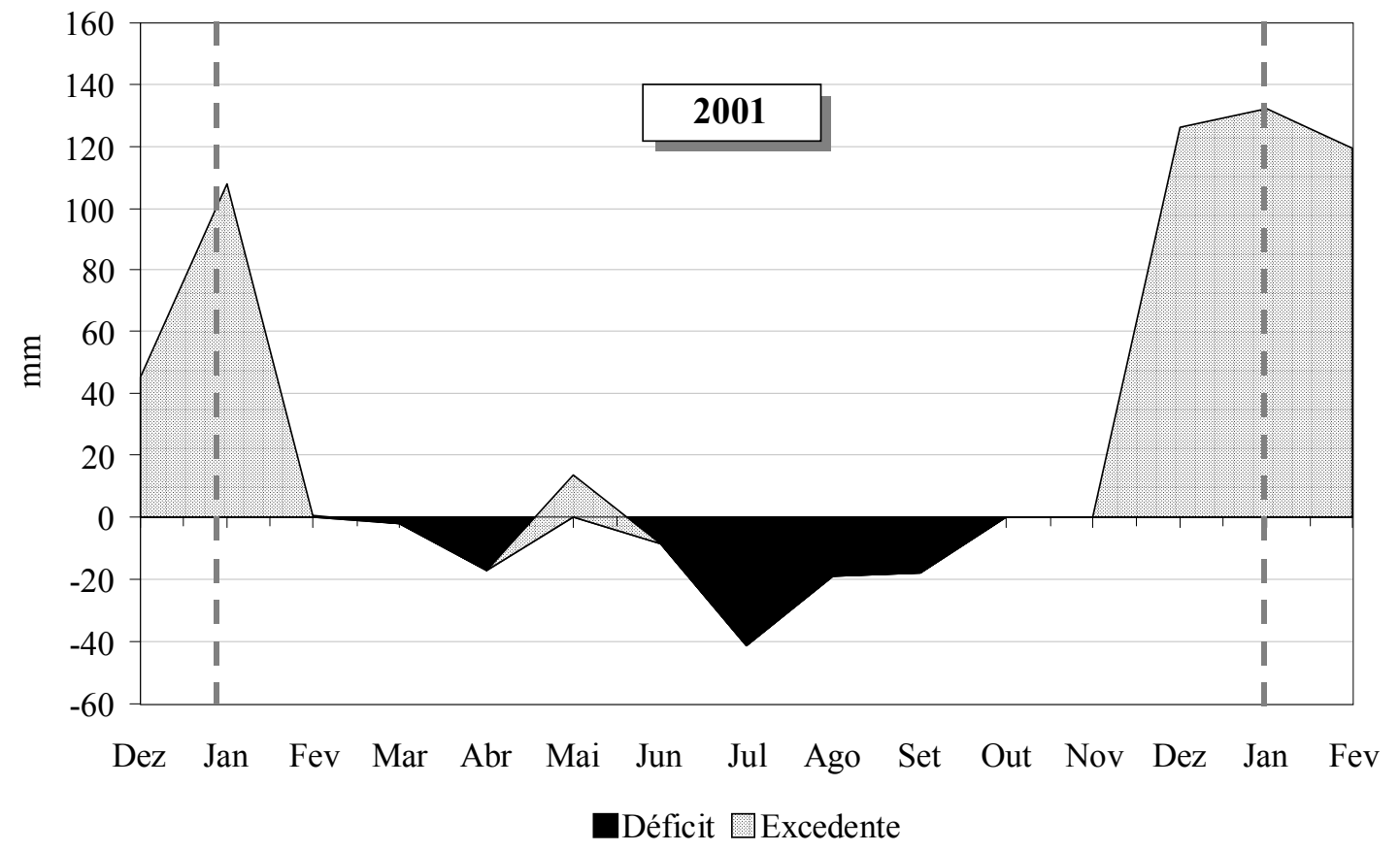

Figura 4 - Balanço hídrico da área experimental de janeiro 2001 a fevereiro de 2002 


\subsubsection{Solo da área experimental}

O experimento foi instalado em solo classificado como Argissolo Vermelho distrófico latossólico (PVd) (EMBRAPA, 1999), de textura muito argilosa e com horizonte A moderado. A análise de terra revelou nível mediano de fertilidade (Tabela 1). De forma geral os piquetes dentro de bloco encontravam-se relativamente homogêneos quanto aos níveis de fósforo e saturação por bases, exceção ao piquete número 5 , bloco 2 , que recebeu $250 \mathrm{~kg} \cdot \mathrm{ha}^{-1}$ de superfosfato simples com a finalidade de elevar o teor de fósforo para $13 \mathrm{mg} \cdot \mathrm{dm}^{-3}$.

Tabela 1. Resultado da análise de terra realizada em setembro de 2000

\begin{tabular}{|c|c|c|c|c|c|c|c|c|c|c|}
\hline Piquete & $\begin{array}{c}\mathrm{P} \\
\mathrm{mg} \cdot \mathrm{dm}^{-3}\end{array}$ & $\begin{array}{l}\text { M.O } \\
\text { g. } \mathrm{dm}^{-3}\end{array}$ & $\begin{array}{c}\mathrm{pH} \\
\mathrm{CaCl}_{2}\end{array}$ & \multicolumn{6}{|c|}{$\mathrm{mmol}_{\mathrm{c}}$} & $\begin{array}{l}\mathrm{V} \\
\%\end{array}$ \\
\hline \multicolumn{11}{|c|}{ Bloco 1} \\
\hline 1 & 7 & 29 & 5,1 & 1,8 & 26 & 15 & 33 & 43,1 & 75,6 & 57 \\
\hline 2 & 9 & 27 & 5,2 & 1,4 & 28 & 13 & 33 & 42,5 & 75,0 & 57 \\
\hline 3 & 8 & 24 & 4,7 & 1,6 & 21 & 12 & 42 & 35,2 & 77,5 & 45 \\
\hline 4 & 7 & 25 & 5,1 & 0,9 & 23 & 11 & 33 & 35,4 & 67,9 & 52 \\
\hline \multicolumn{11}{|c|}{ Bloco 2} \\
\hline 5 & 8 & 25 & 5,4 & 2,5 & 22 & 16 & 26 & 40,3 & 66,6 & 60 \\
\hline 6 & 19 & 32 & 5,8 & 3,7 & 30 & 19 & 22 & 52,7 & 75,2 & 70 \\
\hline 7 & 13 & 35 & 5,5 & 2,7 & 39 & 18 & 29 & 60,0 & 89,2 & 67 \\
\hline 8 & 13 & 35 & 5,3 & 2,1 & 34 & 13 & 33 & 49,6 & 82,1 & 60 \\
\hline \multicolumn{11}{|c|}{ Bloco 3} \\
\hline 9 & 5 & 32 & 5,2 & 1,9 & 22 & 12 & 34 & 35,8 & 70,1 & 51 \\
\hline 10 & 7 & 37 & 5,3 & 1,9 & 24 & 15 & 31 & 40,4 & 71,3 & 57 \\
\hline 11 & 6 & 33 & 5,1 & 2,1 & 26 & 14 & 38 & 42,5 & 80,6 & 53 \\
\hline 12 & 6 & 40 & 5,6 & 2,6 & 29 & 17 & 28 & 48,9 & 76,6 & 64 \\
\hline \multicolumn{11}{|c|}{ Bloco 4} \\
\hline 13 & 6 & 37 & 5,4 & 1,1 & 44 & 14 & 33 & 59,1 & 91,6 & 65 \\
\hline 14 & 8 & 38 & 5,8 & 2,3 & 45 & 18 & 25 & 64,6 & 89,6 & 72 \\
\hline 15 & 8 & 41 & 5,6 & 1,7 & 58 & 22 & 29 & 82,0 & 111,2 & 74 \\
\hline 16 & 8 & 37 & 5,5 & 1,2 & 40 & 18 & 28 & 59,5 & 87,2 & 68 \\
\hline
\end{tabular}




\subsection{Métodos}

\subsubsection{Tratamentos e delineamento experimental}

Os tratamentos corresponderam a duas intensidades combinadas a dois intervalos entre pastejos. Um pastejo intenso, julgado apresentar um nível de utilização de forragem alto, com um resíduo de $30 \mathrm{~cm}$ de altura, e um pastejo mais leniente, deixando-se um resíduo de $50 \mathrm{~cm}$ de altura. Essas intensidades foram combinadas a dois intervalos entre cortes, um correspondente ao tempo necessário para que o dossel forrageiro atingisse um índice de área foliar (IAF) tal que permitisse que 95\% da luz incidente fosse interceptada, e outro quando atingia-se valores próximos de $100 \%$ de interceptação luminosa. Os tratamentos foram alocados às unidades experimentais (16 piquetes com cerca de $2000 \mathrm{~m}^{2}$ ) conforme um delineamento de blocos completos casualizados e arranjo fatorial 2 x 2, com 4 repetições. A distribuição das unidades experimentais (piquetes) na área experimental (layout) é apresentada na Figura 5.

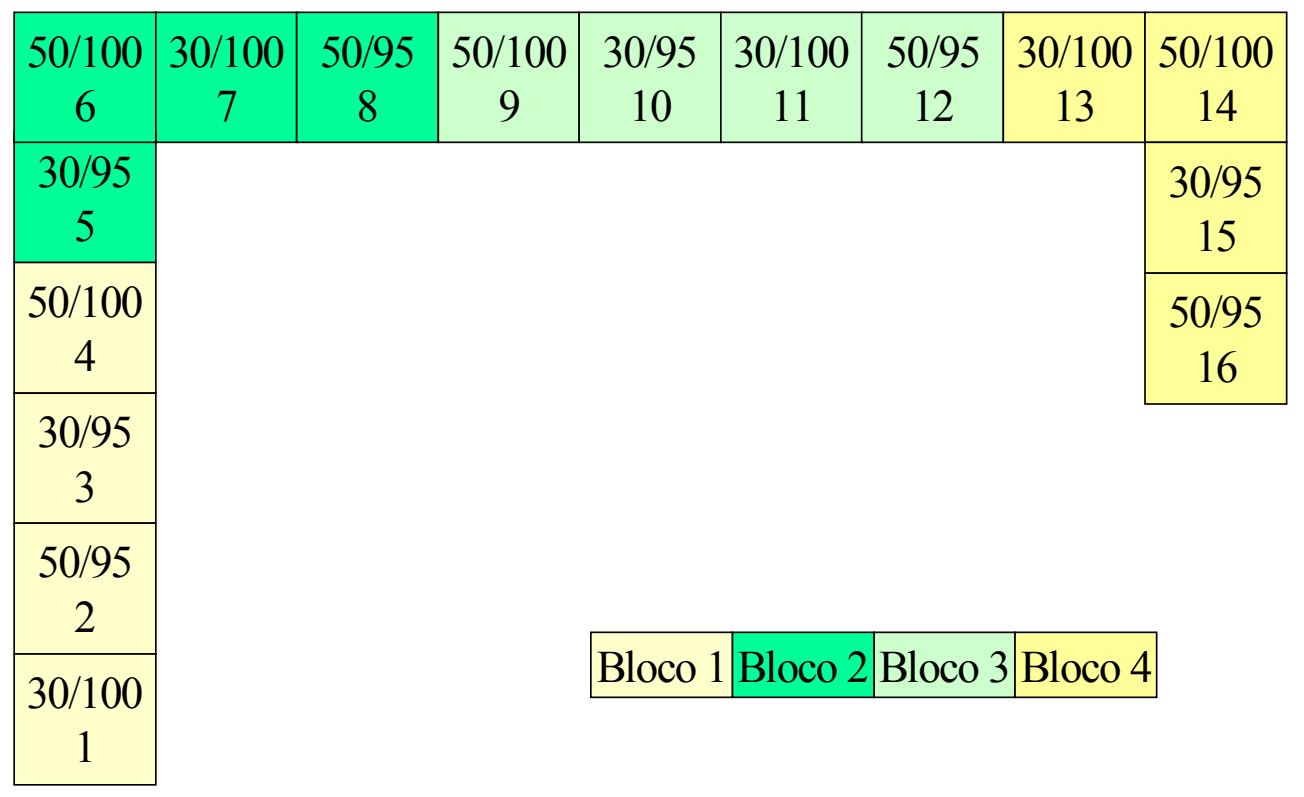

Figura 5 - Representação esquemática da área experimental (Tratamento = resíduo / interceptação luminosa) 
Em setembro de 2000 os piquetes começaram a ser manejados de forma rotacionada e com resíduo de $30 \mathrm{~cm}$ em toda a área experimental. Em dezembro foram implementados os resíduos correspondentes aos tratamentos (30 e $50 \mathrm{~cm}$ ) em cada piquete. Como não havia controle, ainda, do intervalo entre pastejos, houve dificuldades de manutenção dos resíduos propostos, o que levou à necessidade de algumas roçadas manuais após o primeiro pastejo de janeiro de 2001, quando do início do período experimental. Essas roçadas tiveram a finalidade de assegurar que as alturas de resíduo fossem geradas adequadamente, sendo que nos pastejos subseqüentes esse tipo de intervenção não foi mais utilizado.

\subsubsection{Monitoramento das condições experimentais e adubação dos pastos}

O monitoramento da interceptação luminosa foi realizado a cada incremento de $20 \mathrm{~cm}$ na altura do dossel forrageiro após o pastejo $(50,70,90$, etc...) e a cada 2 dias a medida que atingia-se $90 \%$ de interceptação de luz, utilizando-se um aparelho analisador de dossel marca LI-COR modelo LAI 2000 (LI-COR, Lincoln, Nebraska, EUA). Foram utilizadas 6 estações de leitura (amostragem) por piquete, compostas de 5 leituras no nível do solo com uma leitura correspondente acima do nível do dossel em cada estação, totalizando 30 leituras por unidade experimental. Esse número de leituras foi obtido através de simulações do número de estações necessárias em um exercício antes do início das avaliações, sendo que 30 resultou em repetibilidade e precisão satisfatórias dos resultados.

Os piquetes experimentais receberam adubações nitrogenadas diferenciadas por ciclo de pastejo, totalizando $195 \mathrm{~kg} \cdot \mathrm{ha}^{-1}$ de nitrogênio ao final do experimento. Como o intervalo entre pastejos não era fixo, e a condição de entrada dos animais no pasto era também variável, essa quantidade foi dividida por pastejo conforme o período de descanso resultante de cada tratamento, de tal forma que uma quantidade relativamente uniforme por piquete fosse aplicada por mês (Tabela 2).

Tabela 2. Relação da quantidade de $\mathrm{N}\left(\mathrm{kg}_{\mathrm{g}} \mathrm{ha}^{-1}\right)$ aplicada por adubação em cada repetição e a respectiva data de adubação durante o período experimental 


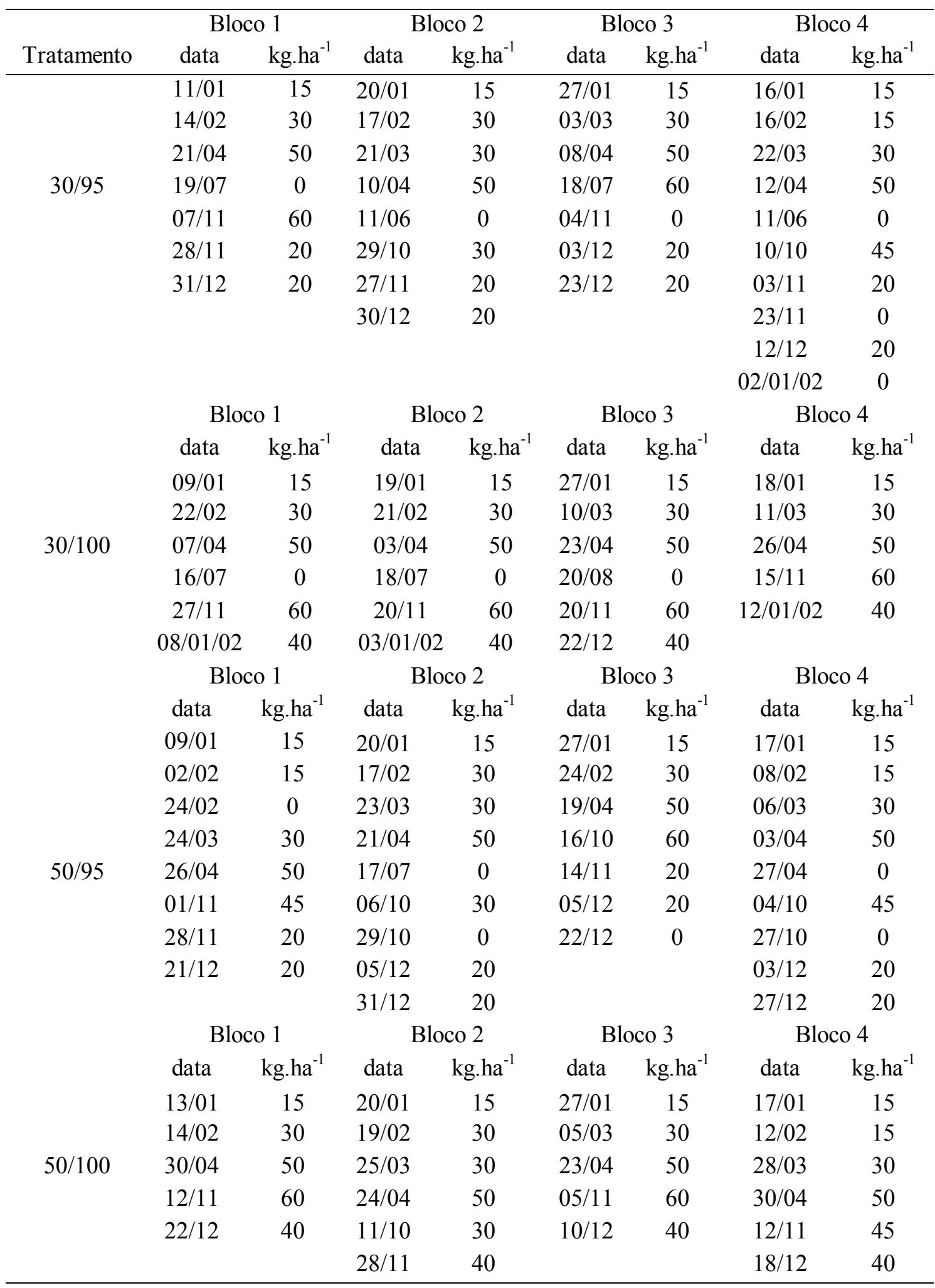




\subsubsection{Altura do dossel forrageiro}

A altura do dossel foi determinada utilizando-se uma régua de madeira de 2 metros de comprimento graduada em centímetros, com a qual foram medidos 16 pontos aleatórios por unidade experimental (Figura 6). A altura de cada ponto correspondeu à altura média do dossel em torno da régua (plano de visão), e a média dos 16 pontos correspondeu a altura média da unidade experimental (piquete).

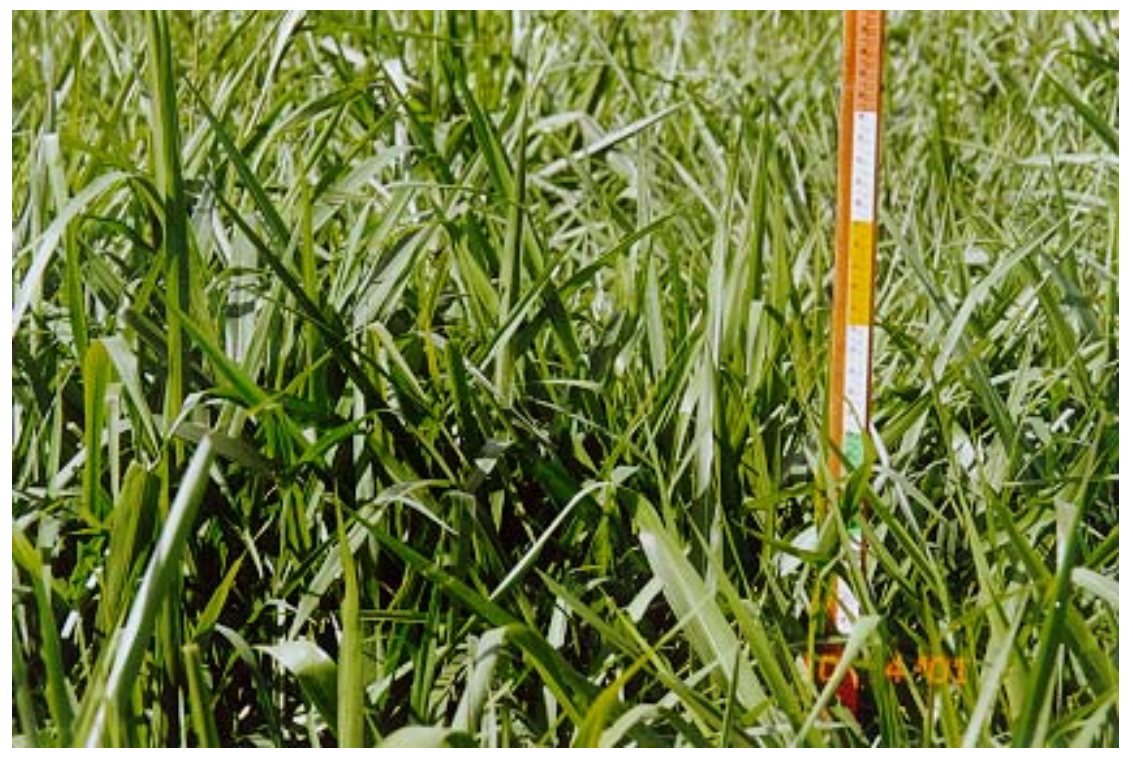

Figura 6 - Régua para a medição da altura do dossel nos piquetes experimentais

\subsubsection{Massa de forragem}

A massa de forragem antes e depois do pastejo foi obtida através do uso de 3 amostradores $(0,68 \times 1,47 \mathrm{~m})$ de $1,0 \mathrm{~m}^{2}$ cada por unidade experimental, padronizando-se o corte da forragem a $20 \mathrm{~cm}$ de altura do solo a fim de não comprometer o estande do pasto (Figura 7). Esses quadrados foram posicionados em pontos que possuíam altura semelhante à altura média da unidade experimental no momento da amostragem, buscando-se pontos que fossem representativos da condição da pastagem. A amostra verde obtida foi pesada e sub-amostrada, e a sub-amostra seca em estufa de circulação 
forçada de ar a $65{ }^{\circ} \mathrm{C}$ para fins de conversão da massa verde da amostra em massa seca. A massa de forragem em cada unidade experimental foi calculada como sendo a média do peso seco das três amostras, valor esse convertido para kg MS.ha ${ }^{-1}$.

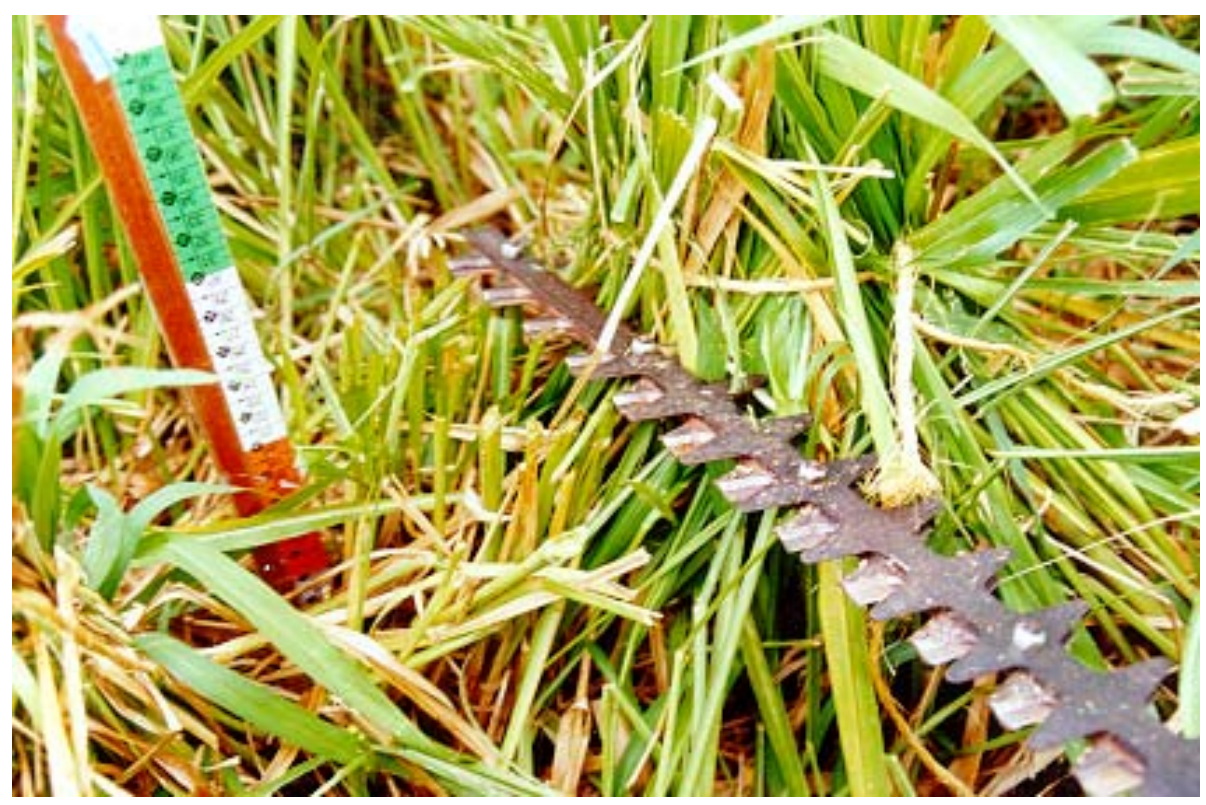

Figura 7 - Corte do capim-Mombaça a $20 \mathrm{~cm}$ do solo para quantificação da massa de forragem no pré-pastejo

\subsubsection{Densidade Volumétrica}

A densidade volumétrica da forragem no dossel foi obtida através do quociente entre a massa de forragem em pré-pastejo e a altura do dossel ajustada para o corte a 20 $\mathrm{cm}$ do solo, sendo expressa em kg MS.cm ${ }^{-1} \cdot \mathrm{ha}^{-1}$. 


\subsubsection{Composição botânica e morfológica da forragem}

A coleta das amostras destinadas às avaliações botânica e morfológica foi realizada no pós-pastejo, durante o período de rebrotação e antes da entrada dos animais nos piquetes (pré-pastejo). Durante o período de rebrotamento as amostragens ocorreram sempre que a altura média do dossel forrageiro apresentava um incremento de $20 \mathrm{~cm}$ em relação ao resíduo e/ou amostragem anterior. $\mathrm{Na}$ ocasião da entrada dos animais nos piquetes era feita uma coleta através do corte de touceiras inteiras, na altura do resíduo desejado, sendo a mesma subdividida em estratos verticais. A estratificação ocorreu da seguinte forma: no momento da coleta a touceira era amarrada com barbante plástico (Figura 8) e, em seguida, com o auxílio de uma régua, as plantas eram divididas de 20 em $20 \mathrm{~cm}$, obtendo-se, assim, os estratos 30-50 (basal) e 50-70 cm (superior) ou 50-70 (basal) e 70-90 cm (superior) para os resíduos de 30 e $50 \mathrm{~cm}$, respectivamente (Figura 9). Para todo o material coletado foi retirada uma sub-amostra de cerca de $250 \mathrm{~g}$ para determinação de sua composição morfológica. O material coletado foi acondicionado em sacos plásticos devidamente identificados e mantidos refrigerados com o intuito de reduzir a perda de água e de nutrientes através da respiração celular enquanto aguardava processamento. Para cada amostra foi retirada uma sub-amostra que foi separada manualmente em: material morto, folhas verdes (lâminas foliares) e hastes (bainhas foliares + hastes). Cada componente, colocado em saquinhos de papel devidamente identificados, foi levado para estufa, seco e pesado. As proporções dos componentes nas amostras foram calculadas como a porcentagem do peso total. A amostra total foi seca em estufa de circulação forçada de ar a $65^{\circ} \mathrm{C}$, em seguida moída em moinho tipo Wiley com peneira de malha $1 \mathrm{~mm}$, e encaminhada para análise química no laboratório de bromatologia. 


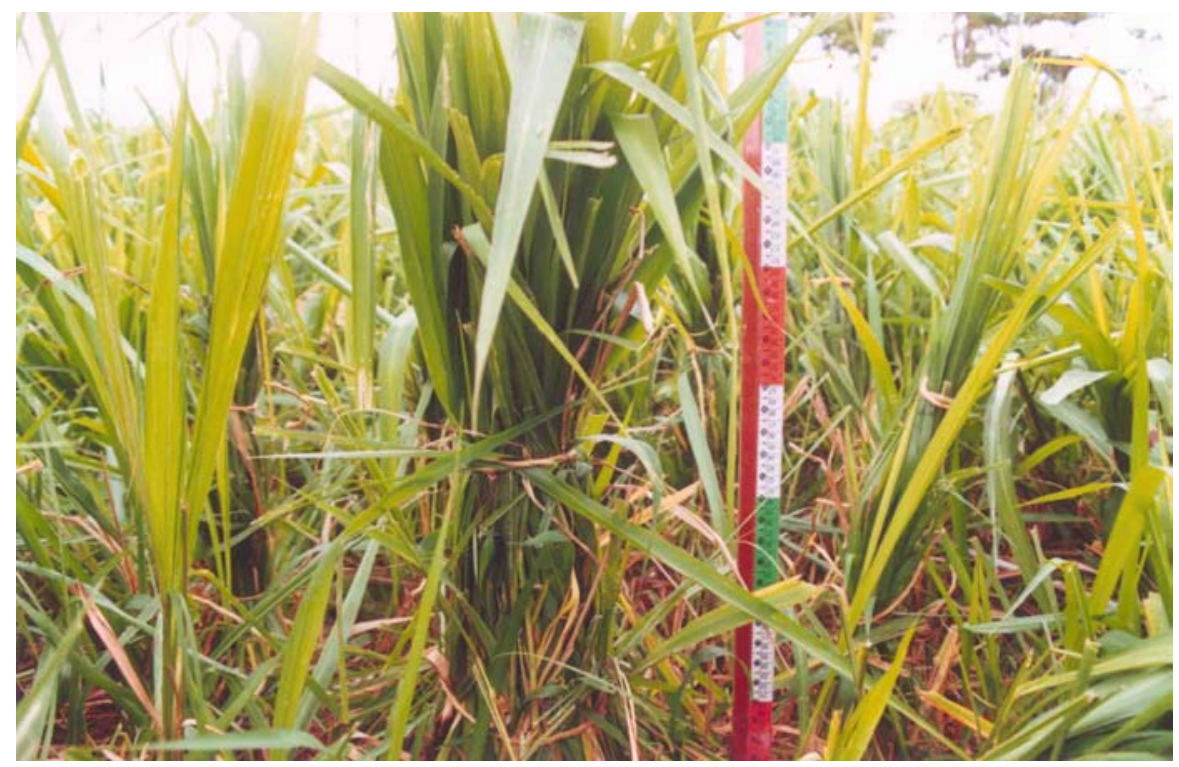

Figura 8 - Touceira de capim-Mombaça destinada a estratificação da forragem

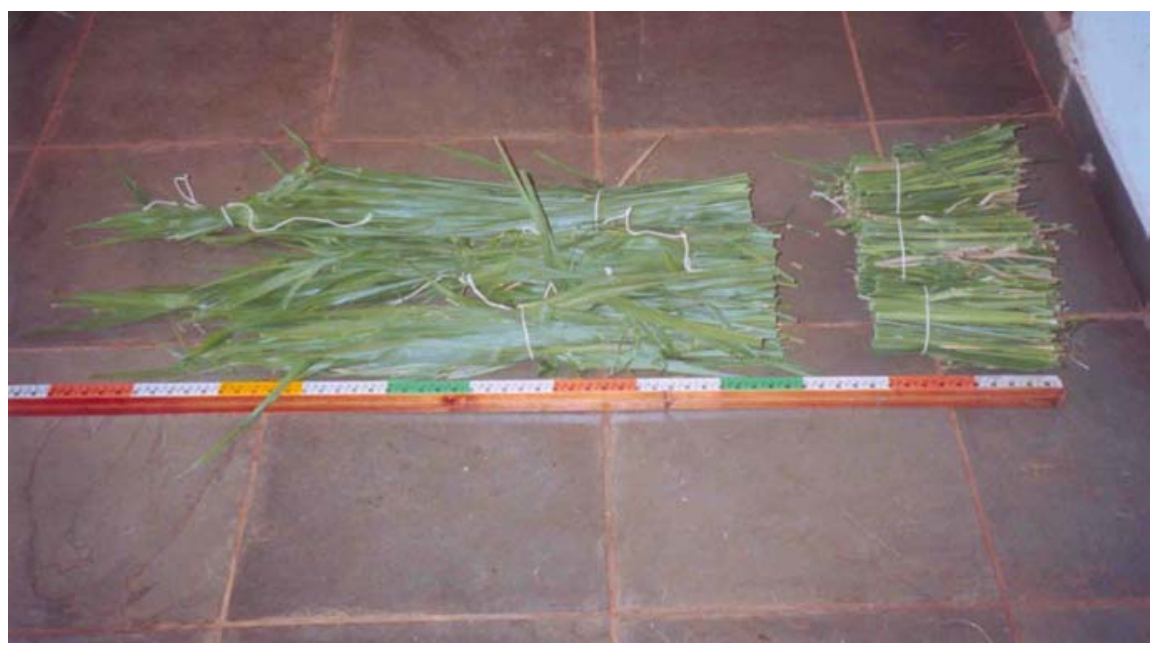

Figura 9 - Forragem estratificada destinada a análise química e composição morfológica 


\subsubsection{Composição Química}

As análises químicas foram realizadas a partir das amostras coletadas conforme descrição anterior. Em cada amostra foram determinados os teores de matéria seca (MS), matéria mineral (MM) e proteína bruta (PB) de acordo com A.O.A.C. (1990), fibra insolúvel em detergente neutro (FDN), fibra insolúvel em detergente ácido (FDA) e lignina segundo o método de Van Soest et al. (1991), e a digestibilidade in vitro da matéria orgânica, segundo o método de Tilley \& Terry (1963) modificado por Goering \& VanSoest (1970).

Para obtenção do teor de MS, uma amostra de forragem de cada unidade experimental foi pesada em duplicata e colocada em estufa a $100{ }^{\circ} \mathrm{C}$ por 12 horas e o material seco pesado. Posteriormente, essa amostra foi queimada em mufla a $600{ }^{\circ} \mathrm{C}$ por três horas, obtendo-se a matéria mineral $(\mathrm{MM})$. O teor de proteína bruta (PB) foi determinado pelo método micro Kjeldahl. O valor do nitrogênio obtido foi multiplicado pelo fator 6,25, resultando no teor de proteína bruta.

Para a determinação dos teores de fibra insolúvel em detergente neutro (FDN) e fibra insolúvel em detergente ácido (FDA) foi utilizado o aparelho Fiber Analyser (Ankon), que propicia uma maior agilidade das atividades e, segundo Van Soest (1982), melhor estimativa do valor nutritivo em plantas forrageiras. A determinação da digestibilidade in vitro da matéria orgânica (DIVMO) foi feita através da utilização do aparelho Daisy Incubator II (Ankon), que também utiliza o mesmo tipo de saquinho utilizado nas análises de FDN e FDA. Esse aparelho propicia maior precisão das análises visto que o ambiente é mantido totalmente anaeróbico, não havendo a necessidade da injeção de $\mathrm{CO}_{2}$ durante a fermentação e o pH também é mantido pela adição de soluções tamponantes no início do processo. 


\subsubsection{Taxas de acúmulo e produção de forragem}

As taxas de acúmulo de forragem foram obtidas a partir da determinação da massa de forragem acumulada, calculada pela diferença entre a massa de forragem no pós-pastejo anterior e no pré-pastejo atual. Esse valor foi dividido pelo número de dias entre pastejos, gerando-se os valores de taxa de acúmulo para cada unidade experimental (piquete) (kg MS.ha $\left.{ }^{-1} \cdot \operatorname{dia}^{-1}\right)$ em cada período de avaliação (ciclo de pastejo). As médias mensais foram calculadas de forma ponderada a partir das taxas de cada ciclo de pastejo com base nas datas de realização dos pastejos.

A produção total de massa seca durante o período experimental foi obtida como resultado da somatória das produções mensais de forragem, calculadas multiplicando-se as taxas de acúmulo mensais pelo número de dias de cada mês.

\subsection{ANÁLISE ESTATÍSTICA}

A análise de variância dos dados foi realizada segundo o procedimento MIXED do pacote estatístico SAS (Statistical Analysis System) (SAS Institute, 1989), versão 6.12 para Windows. As médias foram comparadas através do "LSMEANS", adotando-se o nível de $10 \%$ de significância. Para os dados de acúmulo total de forragem a análise de variância foi feita através do procedimento PROC GLM. 


\section{RESULTADOS E DISCUSSÃO}

Em função da natureza variável do intervalo entre desfolhações determinado pelas duas condições de início do pastejo (95 e 100\% IL), os dados foram agrupados por época do ano (primavera, verão, outono e inverno), exceção feita às taxas de acúmulo de forragem, que foram calculadas mensalmente.

\subsection{Intervalo médio entre pastejos}

$\mathrm{Na}$ Tabela 3 observa-se que para a média da estação de crescimento o principal determinante do intervalo entre pastejos foi o nível de interceptação luminosa para o início do pastejo, independentemente do resíduo. No caso de pastejos iniciados com $100 \%$ IL, o tratamento de resíduo $50 \mathrm{~cm}$ apresentou um intervalo entre pastejos mais curto que o de $30 \mathrm{~cm}$ (33 vs 39 dias). Na média da estação de crescimento (primavera/verão) houve uma diferença de 9 a 16 dias entre os tratamentos de 95 e 100\% IL para os resíduos de 50 e $30 \mathrm{~cm}$, respectivamente, indicando que apesar de pequena, a diferença entre as metas de interceptação luminosa para início do pastejo (5\%) resultou em aumento considerável no intervalo entre pastejos em condições de campo (53\%). O intervalo médio entre pastejos ao longo do período experimental pode ser visualizado na Figura 10. Os valores variaram de 22 dias a 186 dias, sendo que durante a estação das águas (primavera/verão) o intervalo médio foi de 24 e 36 e na seca (outono/inverno) foi de 120 e 150 dias para 95 e 100\% de IL, respectivamente. Esse valores revelam a forte estacionalidade existente entre as épocas do ano, resultando em períodos de descanso 4,$1 ; 2,9 ; 5,8$ e 5,6 vezes mais longos durante o outono/inverno para os tratamentos 
30/95, 30/100, 50/95 e 50/100, respectivamente. No período de outono-inverno a diferença foi de 20 e 46 dias entre os tratamentos de 95 e 100\% IL para os resíduos de 30 e $50 \mathrm{~cm}$, respectivamente, um aumento de $27 \%$ no período de descanso (Figura 10).

Tabela 3. Intervalo médio entre pastejos (dias) de capim-Mombaça submetido a combinações de intervalos entre pastejos (IL) e intensidades de pastejo (altura do resíduo) durante a estação de crescimento*.

\begin{tabular}{cccc}
\hline & \multicolumn{2}{c}{ Resíduo $(\mathrm{cm})$} & \\
Interceptação de Luz $(\%)$ & 30 & 50 & Média \\
\hline 95 & 23 & 24 & 23,5 \\
100 & 39 & 33 & 36,0 \\
Média & 31,0 & 28,5 & \\
\hline
\end{tabular}

*Primavera/verão.

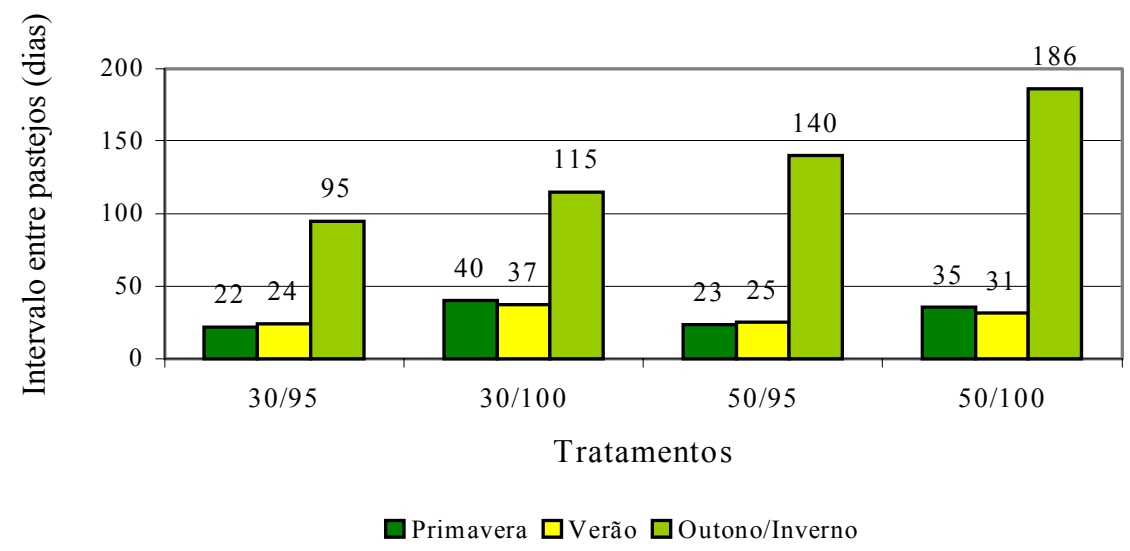

Figura 10 - Intervalo médio entre pastejos (dias) para os tratamentos durante o período experimental

Durante a primavera/verão, época de crescimento vegetativo das plantas, os pastos com resíduo de $50 \mathrm{~cm}$ se recuperaram mais rápido, resultando em menor período de descanso em relação àqueles de resíduo $30 \mathrm{~cm}$. No entanto, durante o período de outono/inverno, época de crescimento reprodutivo e florescimento das plantas, o comportamento foi inverso, com os pastos de resíduo $50 \mathrm{~cm}$ demorando mais para se recuperar que pastos com resíduo $30 \mathrm{~cm}$, provavelmente conseqüência da maior proporção e intensidade de florescimento naquelas condições. Pastos manejados com 
resíduo de $50 \mathrm{~cm}$ apresentaram florescimento mais intenso que os de resíduo $30 \mathrm{~cm}$, assim como os de 100\% em relação aos de 95\% IL (Figuras 11 e 12).

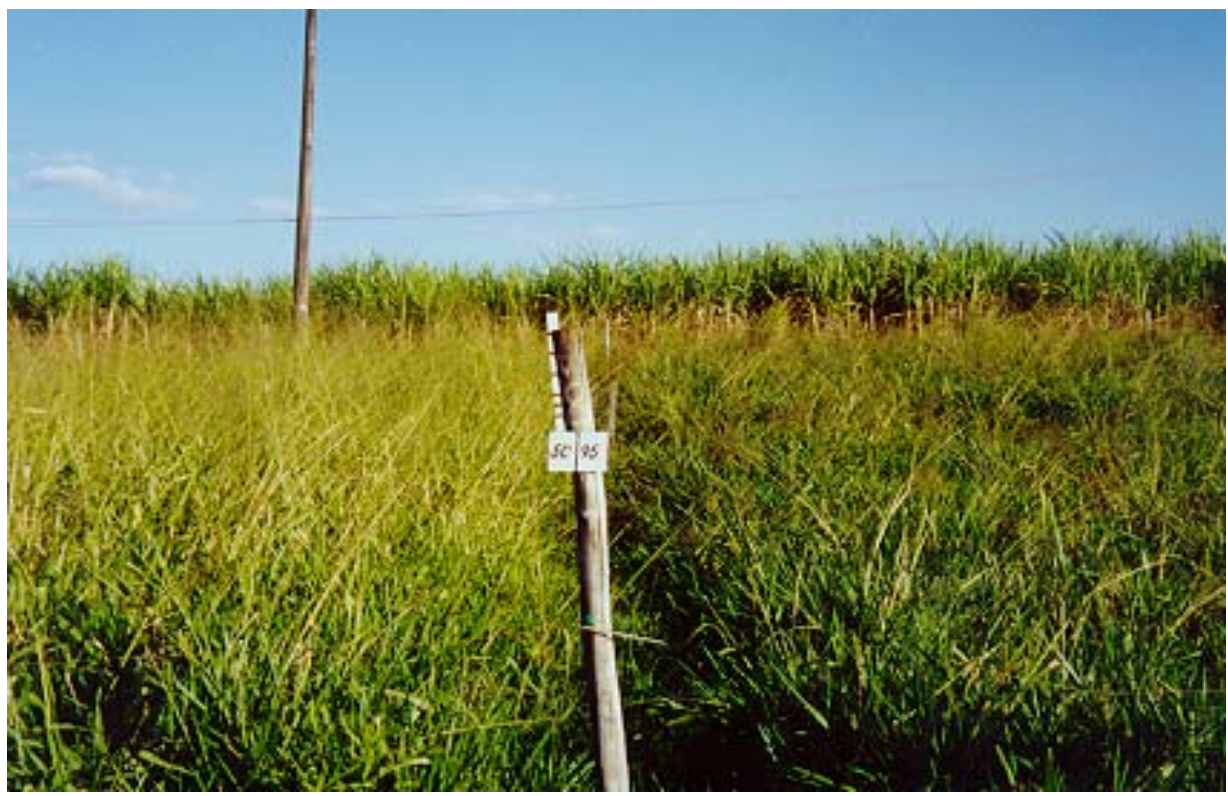

Figura 11 - Florescimento em pastos de capim-Mombaça submetidos ao tratamento 30/100 (esquerda) e 50/95 (direita)

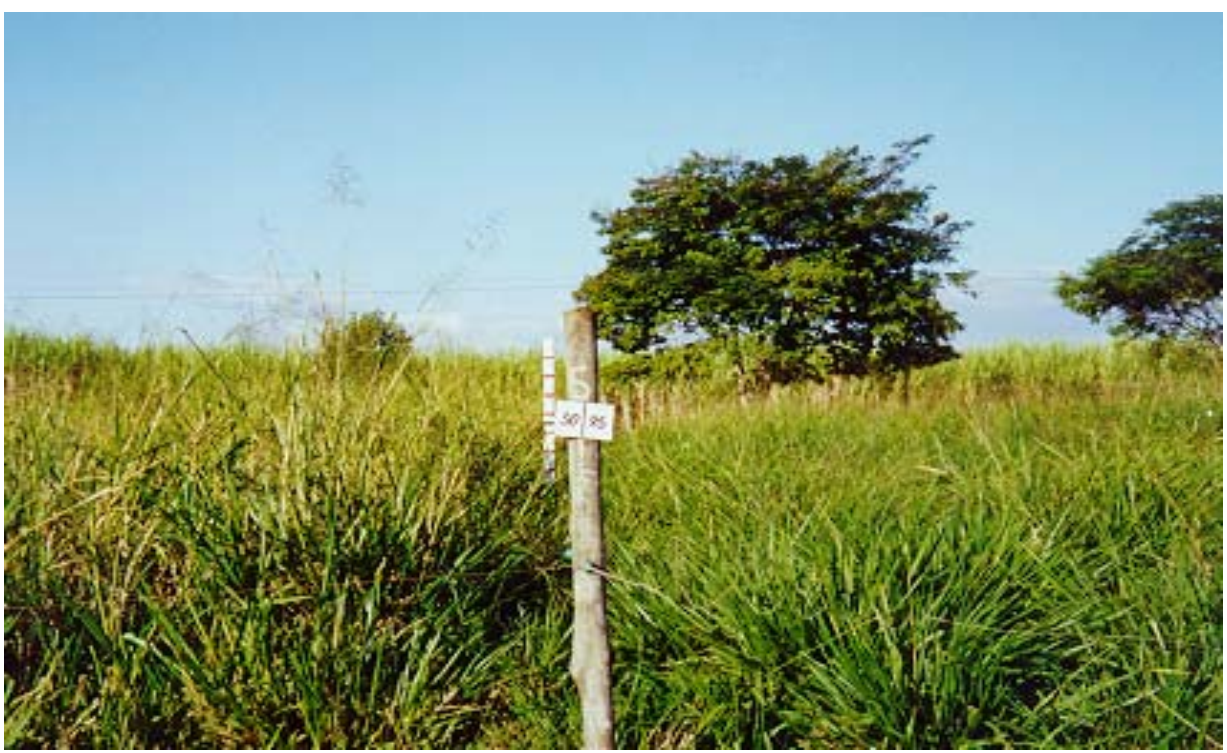

Figura 12 - Florescimento em pastos de capim-Mombaça submetidos ao tratamento 50/100 (esquerda) e 30/95 (direita) 
O período de descanso mais longo pode ter conseqüências sobre a estrutura do dossel forrageiro e o valor nutritivo da forragem produzida, uma vez que pode propiciar um maior acúmulo relativo de hastes e material morto na massa de forragem existente, além de tecido vegetal de idade mais avançada. Nelson \& Moser (1994) e Buxton \& Fales (1994) apontaram a maturidade como o fator mais determinante da morfologia da planta e da qualidade da forragem. Segundo Nelson \& Moser (1994), o conteúdo de parede celular de folhas aumenta apenas cerca de $10 \%$ com a maturidade e, por isso, o declínio na qualidade da forragem é atribuído ao decréscimo da relação folha:haste e ao declínio da qualidade da haste.

Santos (2002) observou queda da digestibilidade "in vitro" da matéria orgânica das gerações mais velhas de perfilhos ao longo do ano ( 3 a 6 pontos percentuais de digestibilidade por ciclo de 33 dias de crescimento). Pinto et al. (1994), em estudo com capim-Guiné (Panicum maximum cv. Guiné), observaram diminuição da relação folha:haste a medida que a idade de rebrotação aumentava, sendo que com 14, 28, 42, 56 e 70 dias encontraram relação folha:haste de 1,$3 ; 1,2 ; 1,0 ; 0,7$ e 0,5 , respectivamente. $\mathrm{O}$ mesmo tipo de comportamento foi determinado por Andrade (1987) avaliando o capimTobiatã (Panicum maximum cv Tobiatã) e Santos (1997) avaliando os capins Mombaça e Tanzânia (Panicum maximum cv Tanzânia).

\subsection{Características estruturais do dossel forrageiro}

\subsubsection{Altura média em pré-pastejo}

Houve efeito de resíduo $(\mathrm{P}=0,0504)$, interceptação luminosa $(\mathrm{P}<0,0001)$ e época do ano $(\mathrm{P}=0,0166)$ para altura do dossel forrageiro na condição de pré-pastejo. Os tratamentos com resíduo de $30 \mathrm{~cm}$ resultaram numa menor altura de dossel por ocasião do início do pastejo em todas as épocas do ano (Tabela 4). Na primavera e no verão, as alturas foram menores devido à menor participação de hastes em florescimento, que elevaram a altura das folhas. 
Tabela 4. Altura do dossel forrageiro ( $\mathrm{cm})$ de capim-Mombaça na condição de prépastejo com pastejos realizados a 30 e $50 \mathrm{~cm}$ de resíduo durante o período de janeiro de 2001 a fevereiro de 2002

\begin{tabular}{cccc}
\hline & \multicolumn{2}{c}{ Resíduo $(\mathrm{cm})$} & 50 \\
Época do ano & 30 & $99,5(3,05)$ & $98,3^{\mathrm{B}}(2,16)$ \\
\hline Primavera & $97,1(3,05)$ & $104,0(3,05)$ & $98,7^{\mathrm{B}}(2,16)$ \\
Verão & $93,3(3,05)$ & $105,1(3,05)$ & $104,6^{\mathrm{A}}(2,16)$ \\
Outono & $104,1(3,05)$ & $109,8(3,05)$ & $107,0^{\mathrm{A}}(2,16)$ \\
Inverno & $104,2(3,31)$ & $104,6^{\mathrm{a}}(1,53)$ & 102,2 \\
Média & $99,7^{\mathrm{b}}(1,56)$ &
\end{tabular}

Médias na mesma coluna seguidas de mesma letra maiúscula não diferem entre si $(\mathrm{P}>0,10)$

Médias na mesma linha seguidas de mesma letra minúscula não diferem entre si $(\mathrm{P}>0,10)$

Valores entre parênteses correspondem ao erro padrão da média

O principal agente determinante da altura do dossel forrageiro por ocasião da entrada dos animais para o pastejo foi a interceptação luminosa. Na Tabela 5, pode-se observar que a diferença de altura do dossel entre 95 e 100\% de interceptação luminosa foi maior que $26 \mathrm{~cm}$ na média das épocas do ano. Durante o ano a diferença oscilou, porém os tratamentos de $95 \%$ de IL tiveram uma altura de dossel consistentemente inferior àquelas dos tratamentos de $100 \%$ de IL.

Tabela 5. Altura do dossel forrageiro $(\mathrm{cm})$ de capim-Mombaça na condição de prépastejo com pastejos realizados a 95 e $100 \%$ de interceptação luminosa do dossel forrageiro durante o período de janeiro de 2001 a fevereiro de 2002

\begin{tabular}{cccc}
\hline & \multicolumn{2}{c}{ Interceptação Luminosa $(\%)$} & Média \\
Época do ano & 95 & 100 & $98,3^{\mathrm{B}}(2,16)$ \\
\hline Primavera & $86,7(3,05)$ & $109,8(3,05)$ & $98,7^{\mathrm{B}}(2,16)$ \\
Verão & $86,9(3,05)$ & $110,4(3,05)$ & $104,6^{\mathrm{A}}(2,16)$ \\
Outono & $92,2(3,05)$ & $116,9(3,05)$ & $107,0^{\mathrm{A}}(2,16)$ \\
Inverno & $88,9(3,05)$ & $125,0(3,31)$ & 102,2 \\
Média & $88,7^{\mathrm{b}}(1,53)$ & $115,5^{\mathrm{a}}(1,56)$ & $100)$
\end{tabular}

Médias na mesma coluna seguidas de mesma letra maiúscula não diferem entre si $(\mathrm{P}>0,10)$

Médias na mesma linha seguidas de mesma letra minúscula não diferem entre si $(P>0,10)$

Valores entre parênteses correspondem ao erro padrão da média 
Além disso, os valores de altura do dossel forrageiro para os tratamentos de 95 e $100 \%$ de IL mantiveram-se relativamente constantes ao longo do ano, sendo cerca de $90 \mathrm{~cm}$ para 95\% de IL (Figura 13) e $115 \mathrm{~cm}$ para 100\% de IL. Esse resultado aponta de forma bastante promissora para o uso da altura do dossel em pré-pastejo como um parâmetro-guia confiável para controle e manejo do pastejo em situações de desfolhação intermitente como, por exemplo, o pastejo rotacionado, desde que seus valores tenham sido obtidos a partir de medidas de IAF e IL correspondentes.

Assim como para o intervalo entre pastejos, o maior efeito observado foi da condição caracterizada pelo início do pastejo aos 95 ou 100\% IL (23\%) relativamente aos resíduos de 30 e $50 \mathrm{~cm}(5,5 \%)$.

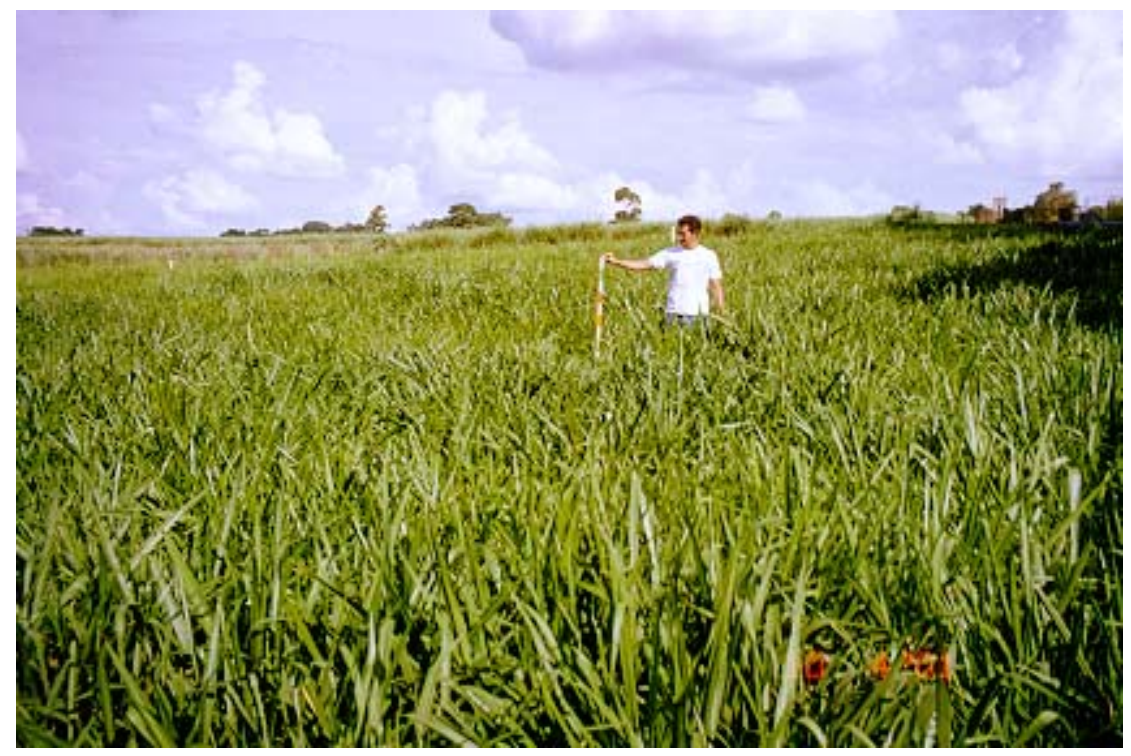

Figura 13 - Altura do dossel forrageiro de capim-Mombaça em pré-pastejo com pastejos realizados a 95\% IL (90 $\mathrm{cm}$ de altura)

\subsubsection{Altura média em pós-pastejo}

Durante toda a fase experimental todos os esforços foram concentrados no sentido de manter as unidades experimentais em conformidade com as metas de resíduo 
pós-pastejo estipuladas (30 e 50cm). Os valores efetivos de altura do resíduo medidos ao longo do experimento são apresentados na Tabela 6.

Tabela 6. Altura pós-pastejo do dossel forrageiro de capim-Mombaça submetido a combinações de intervalos entre pastejos (IL) e intensidades de pastejo (altura do resíduo) durante o período de janeiro de 2001 a fevereiro de 2002

\begin{tabular}{|c|c|c|c|c|}
\hline \multirow[b]{2}{*}{ Resíduo (cm) } & \multicolumn{2}{|c|}{ Interceptação Luminosa (\%) } & \multirow[b]{2}{*}{ Média } & \multirow[b]{2}{*}{ Média Época } \\
\hline & 95 & 100 & & \\
\hline \multicolumn{5}{|c|}{ Primavera } \\
\hline 30 & $33,4^{\mathrm{aB}}(1,52)$ & $33,8^{\mathrm{aB}}(1,52)$ & $33,6^{\mathrm{B}}(1,08)$ & \\
\hline 50 & $48,4^{\text {aA }}(1,52)$ & $50,6^{\text {aA }}(1,52)$ & $49,5^{\mathrm{A}}(1,08)$ & $41,6^{\mathrm{C}}(0,76)$ \\
\hline Média & $40,9^{\mathrm{a}}(1,08)$ & $42,2^{\mathrm{a}}(1,08)$ & & \\
\hline \multicolumn{5}{|c|}{ Verão } \\
\hline 30 & $35,2^{\mathrm{bB}}(1,52)$ & $42,2^{\mathrm{aB}}(1,52)$ & $38,7^{\mathrm{B}}(1,08)$ & $45,3^{\mathrm{B}}(0,76)$ \\
\hline 50 & 50,1 aA $(1,52)$ & $53,5^{\text {aA }}(1,52)$ & $51,8^{\mathrm{A}}(1,08)$ & \\
\hline Média & $42,7^{\mathrm{b}}(1,08)$ & $47,9^{\mathrm{a}}(1,08)$ & & \\
\hline \multicolumn{5}{|c|}{ Outono } \\
\hline 30 & $33,2^{\mathrm{bB}}(1,52)$ & $41,3^{\mathrm{aB}}(1,52)$ & $37,2^{\mathrm{B}}(1,08)$ & \\
\hline 50 & $51,1^{\text {aA }}(1,52)$ & $54,7^{\text {aA }}(1,52)$ & $52,9^{\mathrm{A}}(1,08)$ & $45,1^{\mathrm{B}}(0,76)$ \\
\hline Média & $42,1^{\mathrm{b}}(1,08)$ & $48,0^{\mathrm{a}}(1,08)$ & & \\
\hline \multicolumn{5}{|c|}{ Inverno } \\
\hline 30 & $33,0^{\mathrm{bB}}(1,52)$ & $50,7^{\mathrm{aB}}(1,52)$ & $41,9^{\mathrm{B}}(1,08)$ & \\
\hline 50 & $50,4^{\text {bA }}(1,52)$ & 59,0 aA $(1,52)$ & $54,7^{\mathrm{A}}(1,08)$ & $48,3^{\mathrm{A}}(0,76)$ \\
\hline Média & $41,7^{\mathrm{b}}(1,08)$ & $54,9^{\mathrm{a}}(1,08)$ & & \\
\hline
\end{tabular}

Médias na mesma coluna seguidas de mesma letra maiúscula não diferem entre si $(\mathrm{P}>0,10)$

Médias na mesma linha seguidas de mesma letra minúscula não diferem entre si $(P>0,10)$

Valores entre parênteses indicam erro padrão da média

Houve uma tendência para efeito da interação interceptação luminosa $\mathrm{x}$ resíduo $\mathrm{x}$ época do ano $(\mathrm{P}=0,1119)$ e efeito de interceptação luminosa $(\mathrm{P}<0,0001)$, resíduo $(\mathrm{P}<$ $0,0001)$ e época do ano $(\mathrm{P}<0,0001)$ para os valores de altura pós-pastejo do dossel. Nota-se que a altura do resíduo foi mantida relativamente constante ao longo de todo o ano para o tratamento de resíduo $30 \mathrm{~cm}$ e interceptação luminosa 95\% (Figura 14). Para esse mesmo resíduo, quando a interceptação luminosa considerada foi a de $100 \%$, não 
foi possível manter o mesmo padrão e houve um aumento da altura do resíduo durante o ano particularmente durante o verão, outono e inverno (Figura 15). Esse aumento foi devido à presença de hastes que dificultavam o pastejo, uma vez que as plantas apresentavam-se reprodutivas naquelas épocas do ano. Comportamento semelhante pôde ser observado para o resíduo mantido a $50 \mathrm{~cm}$ com 100\% de interceptação luminosa particularmente durante o inverno (Figura 16). De forma geral, os resíduos foram crescentes ao longo das estações do ano, com os maiores valores observados no período do inverno.

Não houve aumento da altura do resíduo nos pastos manejados a 95\% IL na época de florescimento (outono e inverno) em relação às demais épocas do ano (crescimento vegetativo), indicando que a grande dificuldade no controle de hastes deve estar mais relacionada ao controle do intervalo entre pastejos e que, independentemente da época do ano ou do estádio fenológico da planta (florescimento), o resíduo inicial pode ser mantido se combinado a frequências de desfolhação adequadas.

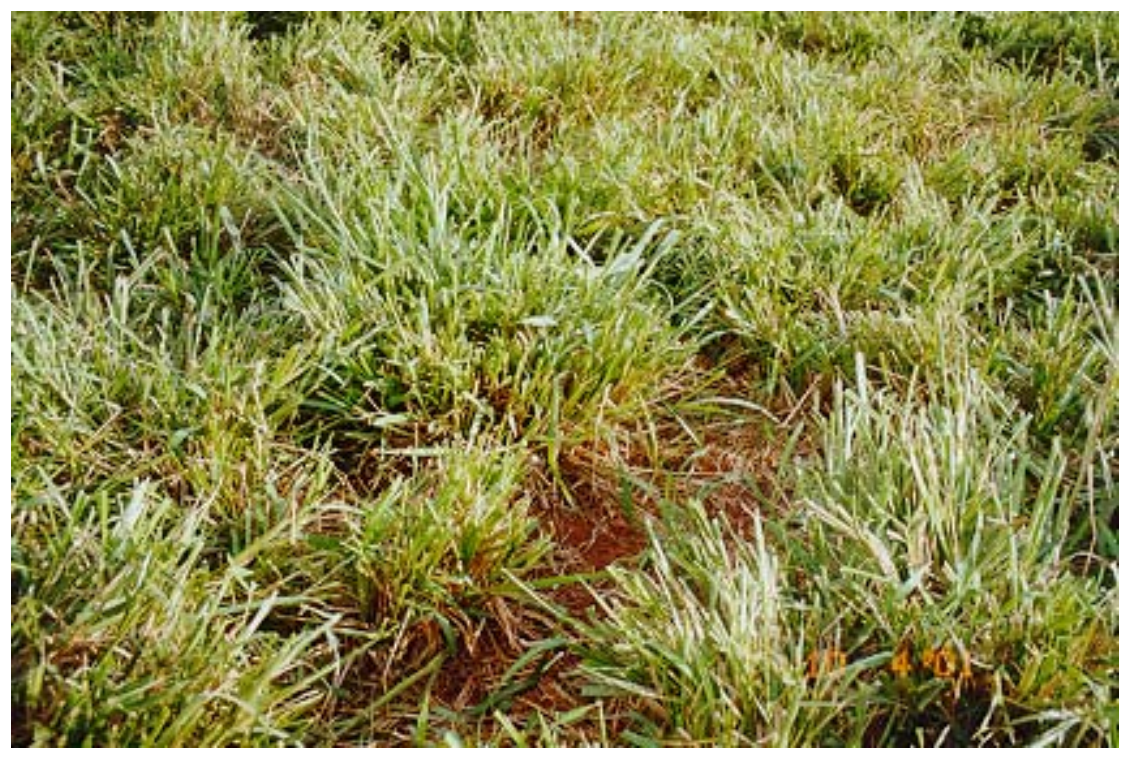

Figura 14 - Resíduo pós-pastejo dos pastos manejados conforme o tratamento 30/95 


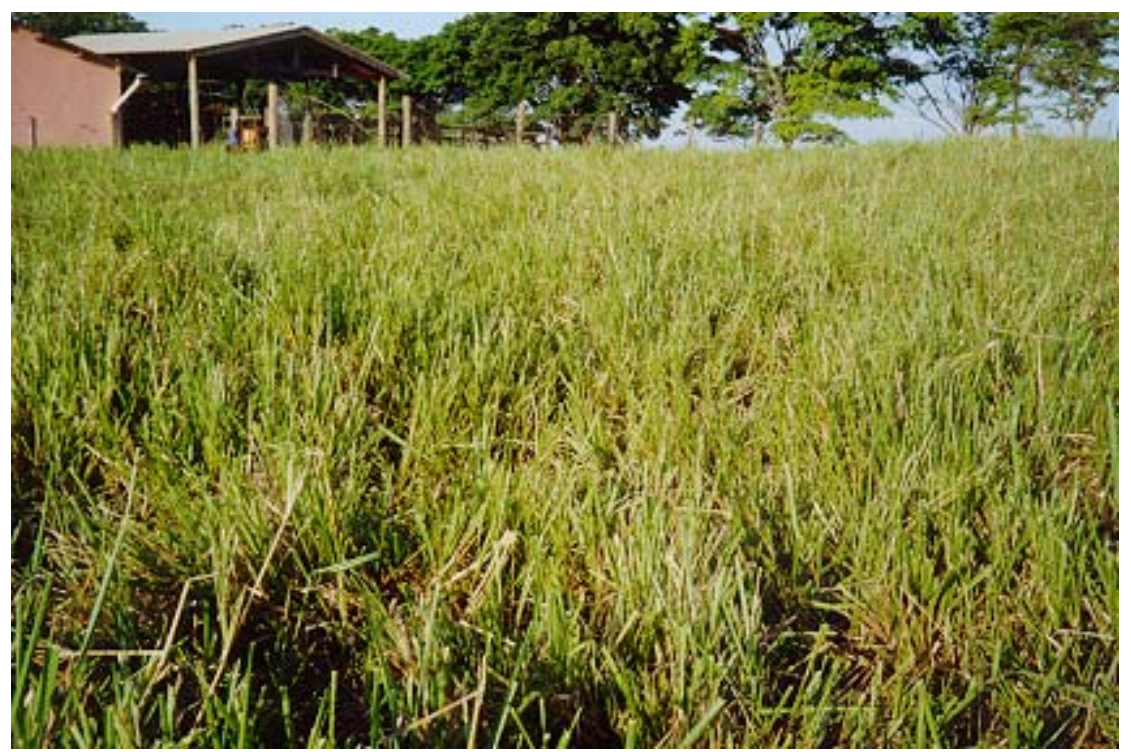

Figura 15 -Resíduo pós-pastejo dos pastos manejados conforme o tratamento 30/100

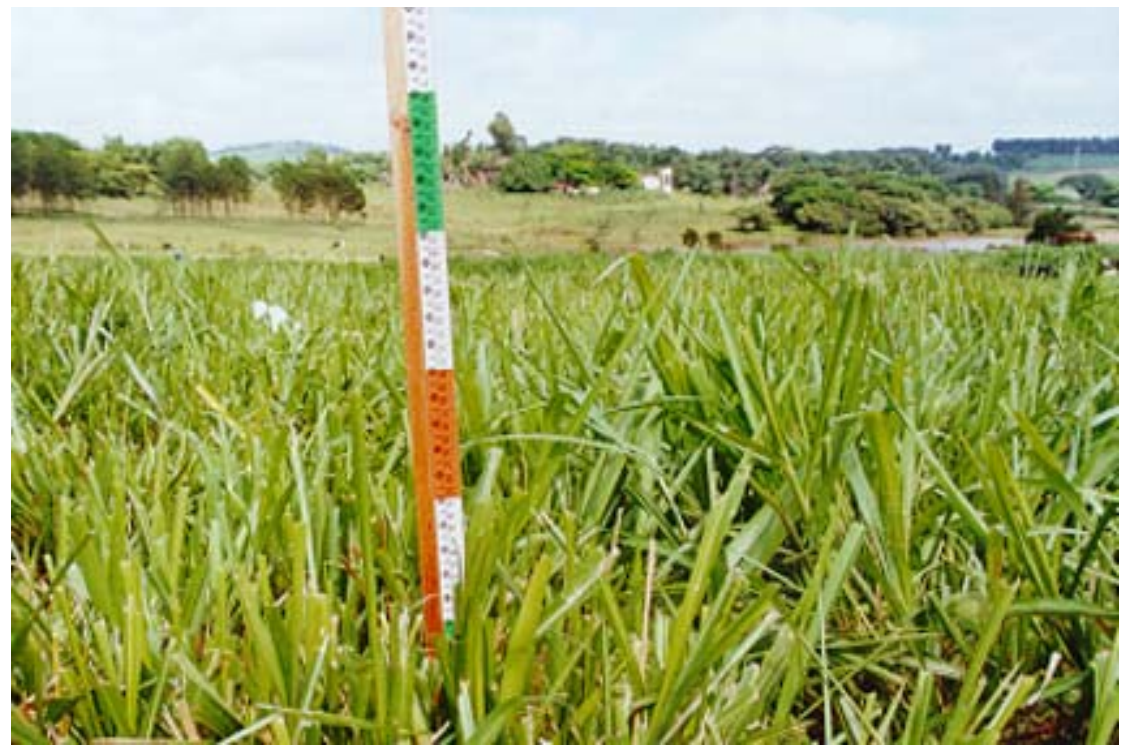

Figura 16 - Resíduo pós-pastejo dos pastos manejados com um resíduo de $50 \mathrm{~cm}$ 


\subsubsection{Massa de forragem em pré-pastejo}

Foram obtidos efeitos de resíduo $(\mathrm{P}=0,0086)$, interceptação luminosa $(\mathrm{P}=0,0001)$ e época do ano $(\mathrm{P}=0,0089)$, além das interações resíduo $\mathrm{x}$ interceptação luminosa $\mathrm{x}$ época do ano $(\mathrm{P}=0,0747)$, resíduo $\mathrm{x}$ época do ano $(\mathrm{P}=0,0011)$ e interceptação luminosa $\mathrm{x}$ época do ano $(\mathrm{P}=0,0015)$. Os valores de massa de forragem em pré-pastejo variaram de 4.300 a $8.900 \mathrm{~kg} \mathrm{MS} \cdot \mathrm{ha}^{-1}$ (Tabela 7).

Tabela 7. Massa de forragem $\left(\mathrm{kg} \mathrm{MS} \mathrm{ha}^{-1}\right)$ na condição de pré-pastejo de capimMombaça submetido a combinações de intervalos entre pastejos (IL) e intensidades de pastejo (altura do resíduo) durante o período de janeiro de 2001 a fevereiro de 2002

\begin{tabular}{|c|c|c|c|c|}
\hline \multicolumn{5}{|c|}{ Interceptação Luminosa (\%) } \\
\hline Resíduo (cm) & 95 & 100 & Média & Média Época \\
\hline \multicolumn{5}{|c|}{ Verão } \\
\hline 30 & $4.800^{\mathrm{bB}}(443)$ & $7.220^{\mathrm{aA}}(443)$ & $6.010^{\mathrm{B}}(313)$ & \\
\hline 50 & $6.190^{\mathrm{bA}}(443)$ & $7.460^{\text {aA }}(443)$ & $6.820^{\mathrm{A}}(313)$ & $6.420^{\mathrm{B}}(221)$ \\
\hline Média & $5.500^{\mathrm{bA}}(313)$ & $7.340^{\text {a B }}(313)$ & & \\
\hline \multicolumn{5}{|c|}{ Outono/Inverno } \\
\hline 30 & $4.300^{\mathrm{bB}}(443)$ & $6.070^{\mathrm{aB}}(443)$ & $5.190^{\mathrm{B}}(313)$ & \\
\hline 50 & $6.320^{\mathrm{bA}}(443)$ & $8.630^{\mathrm{aA}}(443)$ & $7.480^{\mathrm{A}}(313)$ & $6.330^{\mathrm{B}}(221)$ \\
\hline Média & $5.310^{\mathrm{bA}}(313)$ & $7.350^{\text {a B }}(313)$ & & \\
\hline \multicolumn{5}{|c|}{ Primavera } \\
\hline 30 & $4.640^{\mathrm{bB}}(443)$ & $8.920^{\mathrm{aA}}(443)$ & $6.780^{\mathrm{A}}(313)$ & \\
\hline 50 & $5.870^{\mathrm{bA}}(443)$ & $8.690^{\mathrm{aA}}(443)$ & $7.280^{\mathrm{A}}(313)$ & $7.030^{\mathrm{A}}(221)$ \\
\hline Média & $5.260^{\mathrm{bA}}(313)$ & $8.800^{\mathrm{aA}}(313)$ & & \\
\hline
\end{tabular}

Médias na mesma coluna seguidas de mesma letra maiúscula não diferem entre si $(\mathrm{P}>0,10)$ Médias na mesma linha seguidas de mesma letra minúscula não diferem entre si $(\mathrm{P}>0,10)$ Valores entre parênteses indicam erro padrão da média

Os tratamentos de 95\% de IL apresentaram menores valores de massa de forragem que os tratamentos de $100 \%$ de IL, contudo resultaram em um maior número de pastejos (Tabela 8). O maior valor de massa de forragem para os tratamentos de 100 
\% IL foi conseqüência de um período de crescimento mais longo e, provavelmente, maior acúmulo de hastes e material morto (Pinto et al.,1994; Andrade, 1987 e Santos, 1997). Para esses tratamentos não foi observada variação na massa de forragem entre o período de verão e outono/inverno, mesmo com o desenvolvimento reprodutivo e alongamento de hastes de perfilhos induzidos ao florescimento na estação da seca. Para os tratamentos com pastejos iniciados a $95 \%$ IL houve pouco desenvolvimento reprodutivo (Figuras 11 e 12). Braga (2001) avaliou a morfologia de pastos de capimMombaça submetidos a dois intervalos entre cortes (28 e 42 dias) e obteve maior número de perfilhos em desenvolvimento reprodutivo (fase de alongamento de hastes e florescimento) nos tratamentos com 42 dias de intervalo entre cortes, sendo que esses perfilhos exerceram forte influência na produção de massa seca. Santos (1997), em experimento com os capins Mombaça e Tanzânia, observou maior florescimento para pastejos realizados a cada 48 dias em relação àqueles realizados a cada 28 ou 38 dias.

Tabela 8. Número total de pastejos ocorridos em capim-Mombaça submetido a combinações de intervalos entre pastejos (IL) e intensidades de pastejo (altura do resíduo) durante o período de janeiro de 2001 a fevereiro de 2002

\begin{tabular}{cccc}
\hline & \multicolumn{2}{c}{ Interceptação Luminosa (\%) } & Média \\
\hline Resíduo $(\mathrm{cm})$ & 95 & 100 & 6,5 \\
\hline 30 & 7,0 & 6,0 & 7,0 \\
Média & 8,3 & 5,8 & 6,8 \\
\hline
\end{tabular}

Médias na mesma linha seguidas de mesma letra minúscula não diferem entre si $(\mathrm{P}>0,10)$. Valores entre parênteses correspondem ao erro padrão da média.

Os valores médios de massa de forragem durante o ano foram muito semelhantes,

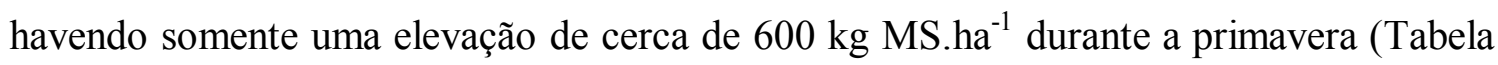
7). Por conta desse padrão de comportamento, a massa de forragem também parece ser um bom parâmetro-guia para indicar o momento da entrada dos animais nos pastos. Entretanto, trata-se de uma medida pouco prática para ser realizada rotineiramente dentro de um sistema de produção. 
A média de massa de forragem foi $5.500 \mathrm{~kg} \mathrm{MS}^{-h^{-1}}$ para 95\%IL e $7.500 \mathrm{~kg}$ MS.ha $^{-1}$ para 100\%IL. Santos (1999), em um estudo sobre o efeito da freqüência de corte sobre a massa de forragem de capim-Mombaça, encontrou 5.700, 8.000 e $8904 \mathrm{~kg}$ MS.ha ${ }^{-1}$ para os intervalos entre cortes de 28,38 e 48 dias, respectivamente.

O número de pastejos dentro de cada época do ano foi variável. Na Tabela 9 , observa-se que houve um maior número de pastejos durante o verão comparativamente à primavera. Além disso, o número de pastejos nos seis meses do ano correspondentes ao período de outono/inverno foi igual aos três meses de primavera, conseqüência das maiores taxas de acúmulo de forragem e velocidade de rebrotação durante esta estação do ano (maior disponibilidade de fatores de crescimento).

Tabela 9. Número de pastejos ocorridos em capim-Mombaça com pastejos realizados a 95 e $100 \%$ de interceptação luminosa do dossel forrageiro durante o período de janeiro de 2001 a fevereiro de 2002

\begin{tabular}{cccc}
\hline & \multicolumn{4}{c}{ Interceptação Luminosa $(\%)$} & \\
Época do ano & 95 & 100 & Média \\
\hline Verão & 3,1 & 2,5 & $2,8^{\mathrm{A}}(0,14)$ \\
Outono/Inverno & 2,3 & 1,8 & $2,0^{\mathrm{B}}(0,13)$ \\
Primavera & 2,6 & 1,4 & $2,0^{\mathrm{B}}(0,17)$ \\
Média & $2,7^{\mathrm{a}}(0,20)$ & $1,9^{\mathrm{b}}(0,20)$ & \\
\hline
\end{tabular}

Médias na mesma coluna seguidas de mesma letra maiúscula não diferem entre si $(\mathrm{P}>0,10)$ Médias na mesma linha seguidas de mesma letra minúscula não diferem entre si $(P>0,10)$

Valores entre parênteses indicam erro padrão da média

\subsubsection{Massa de forragem em pós-pastejo}

$\mathrm{O}$ aumento em altura do dossel forrageiro pós-pastejo refletiu diretamente na massa de forragem pós-pastejo (Tabela 10). Houve efeito de interceptação luminosa ( $\mathrm{P}=0,004)$ e resíduo $(\mathrm{P}=0,0001)$. O tratamento com resíduo de $30 \mathrm{~cm}$ e $95 \%$ de interceptação luminosa foi o que resultou na menor massa de forragem pós-pastejo. 
Apenas com a mudança no momento da entrada dos animais (100\% de IL) houve um aumento de 75\% na massa de forragem residual. No tratamento com resíduo de $50 \mathrm{~cm}$, esse aumento também foi observado, porém em menor proporção $(23 \%)$, devido à grande massa de forragem que não era colhida (Figura 16). Portanto, uma combinação adequada entre o intervalo entre pastejo e o resíduo pós-pastejo evita uma sub-utilização da forragem disponível.

Tabela 10. Massa de forragem (kg MS/ha) de capim-Mombaça na condição de póspastejo submetido a combinações de intervalos entre pastejos (IL) e intensidades de pastejo (altura do resíduo) durante o período de janeiro de 2001 a fevereiro de 2002

\begin{tabular}{cccc}
\hline Resíduo (cm) & \multicolumn{3}{c}{ Interceptação Luminosa (\%) } \\
& 95 & 100 & Média \\
\hline 30 & 1.770 & 3.090 & $2.430^{\mathrm{B}}(144)$ \\
50 & 4.000 & 4.920 & $4.460^{\mathrm{A}}(144)$ \\
Média & $2.880^{\mathrm{b}}(144)$ & $4.000^{\mathrm{a}}(144)$ & 3.440 \\
\hline
\end{tabular}

Médias na mesma coluna seguidas de mesma letra maiúscula não diferem entre si $(\mathrm{P}>0,10)$

Médias na mesma linha seguidas de mesma letra minúscula não diferem entre si $(P>0,10)$

Valores entre parênteses correspondem ao erro padrão da média

\subsubsection{Densidade volumétrica da forragem}

Foi obtido efeito de resíduo $(\mathrm{P}=0,0027)$ e das interações interceptação luminosa $\mathrm{x}$ época do ano $(\mathrm{P}=0,0005)$ e resíduo $\mathrm{x}$ interceptação luminosa x época do ano $(\mathrm{P}=0,0519)$. Os tratamentos de resíduo $50 \mathrm{~cm}$ apresentaram maior valor de densidade volumétrica no período de verão e outono/inverno em relação aos tratamentos de resíduo $30 \mathrm{~cm}$ (Tabela 11). Essa diferença foi decorrente de uma maior presença de hastes ao longo do perfil do dossel (Tabela 39) e material morto na porção inferior do pasto (Tabela 17). No período de primavera essa diferença não ocorreu provavelmente em função do ativo e vigoroso crescimento vegetativo das plantas com significativa renovação da população de perfilhos. 
Com relação à interceptação luminosa, os tratamentos com pastejos iniciados a $95 \%$ IL apresentaram o maior valor de densidade volumétrica que os tratamentos de 100\% IL, exceção feita à primavera, o que caracterizou a interação interceptação luminosa x época do ano. De forma geral, os tratamentos de 95\% IL apresentaram menor altura do dossel que os tratamentos de 100\% IL (Tabela 5), os quais possuíram os maiores valores de massa de forragem (Tabela 7). No entanto, o aumento em massa foi proporcionalmente menor que o aumento correspondente em altura, razão pela qual os valores de densidade volumétrica foram inferiores para os tratamentos de $100 \%$ IL.

Tabela 11. Densidade volumétrica $\left(\mathrm{kg} \mathrm{MS} \cdot \mathrm{cm}^{-1} \cdot \mathrm{ha}^{-1}\right)$ da massa de forragem em prépastejo de capim-Mombaça submetido a combinações de intervalos entre pastejos (IL) e intensidades de pastejo (altura do resíduo) durante o período de janeiro de 2001 a fevereiro de 2002

\begin{tabular}{|c|c|c|c|c|}
\hline \multicolumn{5}{|c|}{ Interceptação Luminosa (\%) } \\
\hline Resíduo (cm) & 95 & 100 & Média & Média Época \\
\hline \multicolumn{5}{|c|}{ Verão } \\
\hline 30 & $76,1^{\mathrm{aB}}(5,17)$ & $72,9^{\mathrm{aA}}(5,17)$ & $74,5^{\mathrm{B}}(3,66)$ & \\
\hline 50 & $92,6^{\mathrm{aA}}(5,17)$ & $77,4^{\mathrm{bA}}(5,17)$ & $85,0^{\mathrm{A}}(3,66)$ & $79,7(2,59)$ \\
\hline Média & $84,3^{\mathrm{a}}(3,66)$ & $75,2^{b}(3,66)$ & & \\
\hline \multicolumn{5}{|c|}{ Outono/Inverno } \\
\hline 30 & $82,2^{\mathrm{aA}}(5,17)$ & $65,8^{\mathrm{bB}}(5,17)$ & $74,0^{\mathrm{B}}(3,66)$ & \\
\hline 50 & $85,2^{\mathrm{aA}}(5,17)$ & $89,9^{\mathrm{aA}}(5,17)$ & $87,5^{\mathrm{A}}(3,66)$ & $80,8(2,59)$ \\
\hline Média & $83,7^{\mathrm{a}}(3,66)$ & $77,9^{\mathrm{a}}(3,66)$ & & \\
\hline \multicolumn{5}{|c|}{ Primavera } \\
\hline 30 & $66,6^{\mathrm{bB}}(5,17)$ & $91,8^{\mathrm{aA}}(5,17)$ & $79,2^{\mathrm{A}}(3,66)$ & \\
\hline 50 & $76,8^{\mathrm{bA}}(5,17)$ & $91,7^{\mathrm{aA}}(5,17)$ & $84,3^{\mathrm{A}}(3,66)$ & $81,7(2,59)$ \\
\hline Média & $71,7^{b}(3,66)$ & $91,8^{\mathrm{a}}(3,66)$ & & \\
\hline
\end{tabular}

Médias na mesma coluna seguidas de mesma letra maiúscula não diferem entre si $(\mathrm{P}>0,10)$. Médias na mesma linha seguidas de mesma letra minúscula não diferem entre si $(\mathrm{P}>0,10)$. Valores entre parênteses indicam erro padrão da média. 
A densidade volumétrica média do experimento foi de cerca de $80 \mathrm{~kg} \mathrm{MS} \cdot \mathrm{cm}^{-1} \cdot \mathrm{ha}^{-1}$, com uma amplitude variando de 66,6 $\mathrm{kg} \mathrm{MS} \cdot \mathrm{cm}^{-1} \cdot \mathrm{ha}^{-1}$ (tatamento 30/95 na primavera) a 92,6 $\mathrm{kg} \mathrm{MS} \cdot \mathrm{cm}^{-1} \cdot \mathrm{ha}^{-1}$ (tratamento 50/95 no verão) (Tabela 11). Esses valores são bastante inferiores àqueles reportados na literatura para outras espécies forrageiras como, Coastcross (Cynodon spp.) (290 kg MS.cm ${ }^{-1} \cdot \mathrm{ha}^{-1}$ - Carnevalli, et al., 2001a), Tyfton 85 (Cynodon spp.) (470 kg MS.cm $\mathrm{cm}^{-1}$ ha - Carnevalli et al., 2001b), Brachiaria brizantha cv Marandu ${ }^{1}\left(450 \mathrm{~kg} \mathrm{MS} \cdot \mathrm{cm}^{-1} \cdot \mathrm{ha}^{-1}\right)$, porém semelhantes àqueles reportados para capimElefante cv. Guaçu (Pennisetum purpureum Schum.) (69 kg MS.cm ${ }^{-1} \mathrm{ha}^{-1}$ - Rosseto, 2000), capim-Elefante cv Napier (35 a $75 \mathrm{~kg} \mathrm{MS.cm}{ }^{-1} \cdot \mathrm{ha}^{-1}$ - Balsalobre, 1996) e capimTanzânia (81 kg MS.cm ${ }^{-1} \cdot \mathrm{ha}^{-1}$ - Rosseto, 2000), espécies de mesmo hábito de crescimento.

\subsubsection{Composição botânica e morfológica}

Os dados apresentados a seguir correspondem ao acompanhamento da composição botânica e morfológica da forragem produzida ao longo dos períodos de rebrotação, iniciando com o resíduo pós-pastejo e terminando com a massa de forragem em pré-pastejo para cada época do ano. O pós-pastejo é referente às alturas de 30 e 50 cm para os tratamentos 30/100, 30/95 e 50/100, 50/95, respectivamente. As avaliações de rebrotação compreenderam as avaliações realizadas quando era observado um incremento de $20 \mathrm{~cm}$ na altura do dossel forrageiro até o momento de um novo pastejo. Assim, as alturas descritas como +20 e +40 são relacionadas a um incremento de 20 e 40 cm na altura do dossel, respectivamente, a partir do resíduo de cada tratamento (30 ou 50 $\mathrm{cm})$.

No momento da entrada dos animais nos piquetes (pré-pastejo), o material coletado foi cortado exatamente na altura planejada de resíduo para os tratamentos e dividido em dois estratos (Figura 9). Os estratos corresponderam a um estrato basal (30-

\footnotetext{
${ }^{1}$ MOLAN, L. K. (Escola Superior de Agricultura "Luiz de Queiroz, Piracicaba, SP). Estrutura do dossel e interceptação luminosa em pastos de Brachiaria brizantha cv. Marandu.
} 
50 e 50-70) e um superior (acima de $50 \mathrm{~cm}$ e acima de $70 \mathrm{~cm}$ ) para os tratamentos de resíduo 30 e $50 \mathrm{~cm}$, respectivamente.

O período de outono/inverno compreendeu a fase reprodutiva de desenvolvimento das plantas nos pastos, que coincidiu com o período de escassez de precipitação (Figuras 2, 3 e 4) e menor disponibilidade de luz. Nessa época do ano, a estrutura do dossel foi modificada em relação ao período vegetativo de crescimento (primavera e verão), razão pela qual o material coletado em pré-pastejo foi dividido em 3 estratos e não 2 como descrito acima e realizado durante os períodos de primavera e verão.

\subsubsection{Composição botânica}

A proporção de invasoras nos piquetes experimentais foi muito pequena. Houve efeito de interceptação luminosa apenas na condição de pós-pastejo $(\mathrm{P}=0,0503)$. $\mathrm{O}$ tratamento de $95 \%$ de IL gerou maior proporção de invasoras do que o tratamento de $100 \%$ IL (1,0 x 0,1\% com $\mathrm{EPM}^{2}=0,31$, respectivamente), provavelmente conseqüência da maior disponibilidade de luz na base do dossel forrageiro. Durante o período de rebrotação não foram observadas diferenças, sendo que na maioria das vezes a presença de plantas invasoras não existiu ou foi quase nula.

$\mathrm{Na}$ condição de pré-pastejo houve efeito de época do ano $(\mathrm{P}=0,0969)$, da interação estrato $\mathrm{x}$ época do ano $(\mathrm{P}=0,0969)$ (Tabela 12) e da interação resíduo $\mathrm{x}$ interceptação luminosa $\mathrm{x}$ época do ano $(\mathrm{P}=0,0969)$ (Tabela 13). Em termos de valores absolutos, a ocorrência de plantas invasoras foi muito baixa em todos os tratamentos e suas repetições, caracterizando os pastos como sendo estandes praticamente puros de capim-Mombaça, forma como a massa de forragem do dossel forrageiro será considerada deste ponto em diante do texto. A proporção de invasoras não foi considerada de forma mais expressiva pois não foram realizados estudos sobre a disponibilidade de banco de sementes na área experimental.

\footnotetext{
${ }^{2}$ Erro padrão da média
} 
Tabela 12. Proporção de plantas invasoras (\% do total) nos estratos basal e superior da massa de forragem pré-pastejo de capim-Mombaça submetido a combinações de intervalos entre pastejos (IL) e intensidades de pastejo (altura do resíduo) durante o período de janeiro de 2001 a fevereiro de 2002

\begin{tabular}{cccc}
\hline & & Estrato & Superior \\
Época do ano & $0,0^{\mathrm{a}}{ }^{\mathrm{B}}(0,02)$ & $0,0^{\mathrm{aA}}(0,02)$ & $0,0^{\mathrm{B}}(0,02)$ \\
\hline Verão & $0,0^{\mathrm{aB}}(0,02)$ & $0,0^{\mathrm{aA}}(0,02)$ & $0,0^{\mathrm{B}}(0,02)$ \\
Outono/Inverno & $0,08^{\mathrm{aA}}(0,02)$ & $0,0^{\mathrm{bA}}(0,02)$ & $0,04^{\mathrm{A}}(0,02)$ \\
Primavera & $0,03^{\mathrm{a}}(0,01)$ & $0,0^{\mathrm{a}}(0,01)$ & \\
Média &
\end{tabular}

Médias na mesma coluna seguidas de mesma letra maiúscula não diferem entre si $(\mathrm{P}>0,10)$

Médias na mesma linha seguidas de mesma letra minúscula não diferem entre si $(\mathrm{P}>0,10)$

Valores entre parênteses indicam erro padrão da média

Tabela 13. Proporção de plantas invasoras (\% do total) na massa de forragem em prépastejo de capim-Mombaça submetido a combinações de intervalos entre pastejos (IL) e intensidades de pastejo (altura do resíduo) durante o período de janeiro de 2001 a fevereiro de 2002

\begin{tabular}{ccccc}
\hline \multicolumn{5}{c}{ Interceptação Luminosa (\%) } \\
Resíduo (cm) & 95 & 100 & Média & Média Época \\
\hline \multicolumn{5}{c}{ Verão } \\
30 & $0,0^{\mathrm{aA}}(0,03)$ & $0,0^{\mathrm{aA}}(0,03)$ & $0,0^{\mathrm{A}}(0,02)$ & \\
50 & $0,0^{\mathrm{aA}}(0,03)$ & $0,0^{\mathrm{aA}}(0,03)$ & $0,0^{\mathrm{A}}(0,02)$ & $0,0^{\mathrm{B}}(0,02)$ \\
Média & $0,0^{\mathrm{a}}$ & $0,0^{\mathrm{a}}$ & & \\
\multicolumn{5}{c}{ Outono/Inverno } \\
30 & $0,0^{\mathrm{aA}}(0,03)$ & $0,0^{\mathrm{aA}}(0,03)$ & $0,0^{\mathrm{A}}(0,02)$ & \\
50 & $0,0^{\mathrm{aA}}(0,03)$ & $0,0^{\mathrm{aA}}(0,03)$ & $0,0^{\mathrm{A}}(0,02)$ & $0,0^{\mathrm{B}}(0,02)$ \\
Média & $0,0^{\mathrm{a}}$ & $0,0^{\mathrm{a}}$ & & \\
30 & $0,05^{\mathrm{aA}}(0,03)$ & $0,0^{\mathrm{aB}}(0,03)$ & $0,0^{\mathrm{A}}(0,02)$ & \\
50 & $0,0^{\mathrm{bA}}(0,03)$ & $0,12^{\mathrm{aA}}(0,03)$ & $0,0^{\mathrm{A}}(0,02)$ & $0,04^{\mathrm{A}}(0,02)$ \\
Média & $0,02^{\mathrm{a}}$ & $0,06^{\mathrm{a}}$ & & \\
\hline
\end{tabular}

Médias na mesma coluna seguidas de mesma letra maiúscula não diferem entre si $(\mathrm{P}>0,10)$ Médias na mesma linha seguidas de mesma letra minúscula não diferem entre si $(P>0,10)$ Valores entre parênteses indicam erro padrão da média 


\subsubsection{Composição morfológica}

\subsection{Material morto}

Houve efeito de resíduo ( $\mathrm{P}=0,0405)$, interceptação luminosa $(\mathrm{P}=0,0924)$ e época do ano $(\mathrm{P}=0,0001)$ na condição de pós-pastejo. Por ocasião da retirada dos animais dos piquetes (término do pastejo), os tratamentos de resíduo $30 \mathrm{~cm}$ apresentaram maior porcentagem de material morto que os tratamentos de resíduo $50 \mathrm{~cm}(34,8$ x 30,4\% com $\mathrm{EPM}=1,45$, respectivamente). Esse fato pode ser explicado pela maior proporção de folhas remanescentes nos tratamentos de resíduo de $50 \mathrm{~cm}$ (Figuras 14, 15 e 16). Com relação à época do ano, não houve diferença entre a primavera e o outono/inverno, enquanto que durante o verão, período de condições ambientais mais favoráveis ao desenvolvimento das plantas, houve decréscimo desse componente nos pastos (Tabela 14). Essa redução da proporção de material morto durante o verão pode ter sido conseqüência da maior atividade de microrganismos responsáveis pela decomposição de matéria orgânica, função das maiores temperaturas médias diárias e disponibilidade de água (Figuras 2, 3 e 4). A maior formação de tecidos nessa época do ano proporcionou maior número de pastejos (Tabela 9), o que possibilitou mudança na luminosidade e pode ter contribuído para diminuição na proporção de material morto.

Tabela 14. Proporção de material morto (\% do total) na massa de forragem em póspastejo de capim-Mombaça submetido a combinações de intervalos entre pastejos (IL) e intensidades de pastejo (altura do resíduo) durante o período de janeiro de 2001 a fevereiro de 2002

\begin{tabular}{cc}
\hline Época do ano & $\%$ Material Morto \\
\hline Verão & $25,6^{\mathrm{B}}(1,78)$ \\
Outono/Inverno & $35,1^{\mathrm{A}}(1,78)$ \\
Primavera & $37,0^{\mathrm{A}}(1,78)$ \\
Média & 32,6
\end{tabular}

Médias na mesma coluna seguidas de mesma letra maiúscula não diferem entre si $(\mathrm{P}>0,10)$ Números entre parênteses correspondem ao erro padrão da média 
Para interceptação luminosa, os tratamentos com pastejos realizados a 100\% IL do dossel forrageiro apresentaram maior proporção de material morto do que os tratamentos com 95\% IL no resíduo pós-pastejo $(34,4$ x 30,8\% com EPM=1,46, respectivamente). Essa diferença foi consequência do maior intervalo entre pastejos, que deve ter favorecido maior senescência de tecidos mais velhos.

Durante o período de rebrotação, houve efeito de época do ano $(\mathrm{P}=0,0001)$ e das interações interceptação luminosa $\mathrm{x}$ época do ano $(\mathrm{P}=0,0103)$ e resíduo $\mathrm{x}$ altura de rebrotação x época do ano $(\mathrm{P}=0,0105)$. As maiores proporções de material morto foram observadas durante o período de outono/inverno, seguidas daquelas da primavera e do verão (Tabela 15).

Tabela 15. Proporção de material morto (\%) na massa de forragem durante a rebrotação de capim-Mombaça após pastejos realizados a 95 e $100 \%$ de interceptação luminosa do dossel forrageiro durante o período de janeiro de 2001 a fevereiro de 2002

\begin{tabular}{cccc}
\hline & \multicolumn{2}{c}{ Interceptação de Luminosa $(\%)$} & Média \\
\hline Época do ano & 95 & 100 & $2,0^{\mathrm{C}}(0,23)$ \\
Verão & $2,4^{\mathrm{aC}}(0,33)$ & $1,6^{\mathrm{bC}}(0,33)$ & $13,8^{\mathrm{A}}(2,37)$ \\
Outono/Inverno & $13,1^{\mathrm{aA}}(2,87)$ & $14,4^{\mathrm{aA}}(3,79)$ & $5,8^{\mathrm{B}}(0,61)$ \\
Primavera & $4,2^{\mathrm{bB}}(0,87)$ & $7,5^{\mathrm{aB}}(0,87)$ & \\
Média & $6,6^{\mathrm{a}}(1,03)$ & $7,8^{\mathrm{a}}(1,33)$ & \\
\hline
\end{tabular}

Médias na mesma coluna seguidas de mesma letra maiúscula não diferem entre si $(\mathrm{P}>0,10)$

Médias na mesma linha seguidas de mesma letra minúscula não diferem entre si $(\mathrm{P}>0,10)$

Valores entre parênteses indicam erro padrão da média

Essa ordem de classificação reflete a passagem da época do ano de pastos reprodutivos e secos pela fase de início das chuvas e incremento de temperatura até a fase de crescimento mais ativo e vigoroso, o verão, época do ano em que a atividade de microrganismos é bastante elevada e responsável pelos processos de decomposição de matéria orgânica no solo e na base do dossel forrageiro. Maiores proporções de hastes e material senescente e morto são características típicas de pastos em estádio reprodutivo comparativamente a pastos em estádio vegetativo de desenvolvimento, conseqüência do 
ambiente luminoso de pior qualidade e elevada mortalidade de perfilhos. A interação interceptação luminosa $\mathrm{x}$ época do ano foi ocasionada pela maior proporção de material morto para os tratamentos de 95\% IL em relação aos de 100\% IL no verão, provavelmente conseqüência da maior mortalidade de perfilhos por pastejos mais freqüentes naquela época do ano (Uebele, 2002). Nas outras épocas as proporções de material morto haviam sido maiores para os tratamentos de $100 \%$ IL, consequiência do maior desenvolvimento reprodutivo dos pastos mantidos naquelas condições.

A interação resíduo $\mathrm{x}$ altura de rebrotação $\mathrm{x}$ época do ano deve ter sido conseqüência de um aumento na proporção de material morto para os tratamentos de resíduo $50 \mathrm{~cm}$ no estrato +40 no período de primavera em relação ao período de outono/inverno (Tabela 16). Provavelmente isso refletiu o efeito residual de regimes de desfolhação de uma época para outra ao longo do ano. Durante o verão, os tratamentos de resíduo $30 \mathrm{~cm}$ ocasionaram maior mortalidade de perfilhos que os de resíduo $50 \mathrm{~cm}$ (Uebele, 2002), o reflexo disso sendo mostrado no período seguinte, outono/inverno. Durante esse período, os tratamentos de resíduo $50 \mathrm{~cm}$ apresentaram a maior proporção de perfilhos florescidos e florescimento mais intenso, cujas hastes decapitadas e mortas ocasionaram a maior proporção de material morto notada na estação seguinte, a primavera. Dessa forma as conseqüências das práticas de manejo são claras e mostram que colheita mais eficiente de forragem associada a controle do processo reprodutivo dos pastos asseguram melhores condições para início de crescimento durante a primavera. Pastejos mais lenientes durante a época de crescimento ativo das plantas forrageiras resultaram em maior florescimento e comprometimento da estrutura do pasto numa época crítica do ano, o início da nova estação de crescimento, ou seja, a primavera. Esse comprometimento foi caracterizado pelas menores taxas de aparecimento e densidade populacional de perfilhos (Uebele, 2002). 
Tabela 16. Proporção de material morto (\%) na massa de forragem durante a rebrotação de capim-Mombaça após pastejos realizados a 30 e $50 \mathrm{~cm}$ de resíduo durante o período de janeiro de 2001 a fevereiro de 2002

\begin{tabular}{|c|c|c|c|c|}
\hline \multicolumn{5}{|c|}{ Fase de Rebrotação } \\
\hline Resíduo (cm) & +20 & +40 & Média & Média Época \\
\hline \multicolumn{5}{|c|}{ Verão } \\
\hline 30 & $3,3^{\mathrm{aA}}(0,46)$ & $1,5^{\mathrm{bA}}(0,46)$ & $2,4^{\mathrm{A}}(0,33)$ & \\
\hline 50 & $1,8{ }^{\mathrm{aB}}(0,46)$ & $1,4^{\mathrm{aA}}(0,46)$ & $1,6^{\mathrm{B}}(0,33)$ & $2,0^{\mathrm{C}}(0,23)$ \\
\hline Média & $2,6^{\mathrm{a}}(0,33)$ & $1,5^{\mathrm{b}}(0,33)$ & & \\
\hline \multicolumn{5}{|c|}{ Outono/Inverno } \\
\hline 30 & $13,3^{\mathrm{aA}}(4,06)$ & $15,3^{\mathrm{aA}}(4,06)$ & $14,3^{\mathrm{A}}(2,87)$ & \\
\hline 50 & $20,2^{\mathrm{aA}}(4,06)$ & $6,3^{\mathrm{bA}}(4,06)$ & $13,2^{\mathrm{A}}(3,79)$ & $13,8^{\mathrm{A}}(2,38)$ \\
\hline Média & $16,8^{\text {a }}(2,87)$ & $10,7^{\mathrm{a}}(3,79)$ & & \\
\hline \multicolumn{5}{|c|}{ Primavera } \\
\hline 30 & $7,4^{\mathrm{aA}}(1,24)$ & $2,6^{\mathrm{bB}}(1,24)$ & $5,0^{\mathrm{A}}(0,87)$ & \\
\hline 50 & $5,3^{\mathrm{bA}}(1,24)$ & $8,1^{\text {aA }}(1,24)$ & $6,7^{\mathrm{A}}(0,87)$ & $5,8^{\mathrm{B}}(0,62)$ \\
\hline Média & $6,3^{\text {a }}(0,87)$ & $5,4^{\mathrm{a}}(0,87)$ & & \\
\hline
\end{tabular}

Médias na mesma coluna seguidas de mesma letra maiúscula não diferem entre si $(\mathrm{P}>0,10)$

Médias na mesma linha seguidas de mesma letra minúscula não diferem entre si $(\mathrm{P}>0,10)$

Valores entre parênteses indicam erro padrão da média

$\mathrm{Na}$ condição de pré-pastejo, houve efeito de resíduo $(\mathrm{P}=0,0263)$, interceptação luminosa $(\mathrm{P}=0,0279)$, estrato $(\mathrm{P}=0,0001)$ e época do ano $(\mathrm{P}=0,0001)$, além das interações interceptação luminosa x época do ano $(\mathrm{P}=0,0040)$ e resíduo x estrato. Foi observada uma maior proporção de material morto para os tratamentos de resíduo $30 \mathrm{~cm}$ $(9,7 \%)$ em relação aos de $50 \mathrm{~cm}(6,4 \%)$ (Tabela 17), diferentemente dos resultados de Gomes (2001), que encontrou maior proporção de material morto para pastejos mais lenientes. Essa maior quantidade de material morto para o resíduo de $30 \mathrm{~cm}$ foi resultado do maior período de descanso observado quando associou-se a essa intensidade de pastejo desfolhações realizadas com 100\% IL do dossel forrageiro (Tabela 3).

Com relação à interceptação de luz, os tratamentos com pastejos iniciados com $100 \%$ IL apresentaram as maiores proporções de material morto comparativamente àqueles de 95\% IL (Tabela 18), provavelmente conseqüência da maior altura dos pastos (Tabela 5) e resultante da menor disponibilidade de luz no interior do dossel forrageiro. Gomes (2001) encontrou relação crescente e linear entre a proporção de material morto e o aumento em oferta de forragem em seu trabalho com capim-Mombaça. 
Tabela 17. Proporção de material morto (\%) nos estratos basal e superior da massa de forragem em pré-pastejo de capim-Mombaça com pastejos realizados a $30 \mathrm{e}$ $50 \mathrm{~cm}$ de resíduo durante o período de janeiro de 2001 a fevereiro de 2002

\begin{tabular}{cccc}
\hline & \multicolumn{2}{c}{ Estrato } & Muperior \\
Resíduo $(\mathrm{cm})$ & Basal & Média \\
\hline 30 & $15,8^{\mathrm{aA}}(1,37)$ & $3,56^{\mathrm{bA}}(1,37)$ & $9,7^{\mathrm{A}}(0,97)$ \\
50 & $10,2^{\mathrm{aB}}(1,37)$ & $2,71^{\mathrm{bA}}(1,37)$ & $6,4^{\mathrm{B}}(0,97)$ \\
Média & $13,0^{\mathrm{a}}(0,96)$ & $3,1^{\mathrm{b}}(0,96)$ & \\
\hline
\end{tabular}

Médias na mesma coluna seguidas de mesma letra maiúscula não diferem entre si $(P>0,10)$

Médias na mesma linha seguidas de mesma letra minúscula não diferem entre si $(P>0,10)$

Valores entre parênteses indicam erro padrão da média

Tabela 18. Proporção de material morto (\%) na massa de forragem em pré-pastejo de capim-Mombaça com pastejos realizados a 95 e $100 \%$ de interceptação luminosa do dossel forrageiro durante o período de janeiro de 2001 a fevereiro de 2002

\begin{tabular}{cccc}
\hline & \multicolumn{2}{c}{ Interceptação Luminosa $(\%)$} & \\
Época do ano & 95 & 100 & Média \\
\hline Verão & $4,5^{\mathrm{aB}}(0,87)$ & $4,8^{\mathrm{aB}}(0,87)$ & $4,6^{\mathrm{B}}(0,61)$ \\
Outono/Inverno & $9,4^{\mathrm{aA}}(2,28)$ & $11,9^{\mathrm{aA}}(2,28)$ & $10,7^{\mathrm{A}}(1,61)$ \\
Primavera & $5,4^{\mathrm{bAB}}(1,76)$ & $12,3^{\mathrm{aA}}(1,76)$ & $8,9^{\mathrm{A}}(1,24)$ \\
Média & $6,5^{\mathrm{b}}(0,98)$ & $9,7^{\mathrm{a}}(0,98)$ &
\end{tabular}

Médias na mesma coluna seguidas de mesma letra maiúscula não diferem entre si $(\mathrm{P}>0,10)$

Médias na mesma linha seguidas de mesma letra minúscula não diferem entre si $(\mathrm{P}>0,10)$

Valores entre parênteses indicam erro padrão da média

Quanto à época do ano, o efeito foi o mesmo já descrito para as condições de pós-pastejo e rebrotação, ou seja, maiores proporções de material morto no outono/inverno, seguido da primavera e verão. $\mathrm{O}$ efeito da interação interceptação luminosa x época do ano pôde ser observado quando para os pastejos realizados a $100 \%$ de IL foram encontradas as menores proporções de material morto durante o verão comparativamente às demais épocas do ano. Provavelmente a maior disponibilidade de 
luz no verão compensou parcialmente o efeito negativo do maior período de descanso e altura dos pastos de 100\% IL naquela época do ano. Nas demais épocas, quando a disponibilidade de luz era menor, os efeitos negativos da menor freqüência de desfolhação foram mais drásticos. Na primavera, a proporção de material morto foi sensivelmente maior para o pastejo iniciado com 100\% IL (12,3\%) relativamente ao pastejo iniciado com 95\% IL (5,4\%), indicando, mais uma vez, que um intervalo entre pastejos mais longo resulta em maiores perdas por senescência e morte de tecidos não colhidos. Teixeira (1999) verificou variação anual de 3,6 a 18,9\% de material morto na forragem disponível de capim-Tobiatã. Já Brâncio et al. (2000) constataram participações médias superiores, variando de 21 a $54 \%$ de material morto na forragem disponível dos cultivares Tanzânia, Mombaça e Massai de Panicum maximum.

Com relação aos estratos do dossel, ficou aparente a menor concentração de material morto nos estratos superiores do pasto, indicando que a maior proporção de material morto na base dos pastos pode ser potencialmente negativa para o perfilhamento das plantas (Tabela 19). Esses valores ilustram também a afirmação de Brâncio (1996) de que a seletividade dos animais faz com que a proporção de hastes e material morto aumente do início para o final do período de pastejo.

Tabela 19. Proporção de material morto (\%) nos estratos basal e superior da massa de forragem em pré-pastejo de capim-Mombaça submetido a combinações de intervalos entre pastejos (IL) e intensidades de pastejo (altura do resíduo) durante o período de janeiro de 2001 a fevereiro de 2002

\begin{tabular}{cccc}
\hline & Basal & Estrato & Superior \\
Época do ano & $8,18^{\mathrm{aB}}(0,87)$ & $1,1^{\mathrm{bA}}(0,87)$ & $4,6^{\mathrm{B}}(0,61)$ \\
\hline Verão & $16,5^{\mathrm{aA}}(2,28)$ & $4,8^{\mathrm{aAB}}(2,28)$ & $10,7^{\mathrm{A}}(1,61)$ \\
Outono/Inverno & $14,3^{\mathrm{aA}}(1,76)$ & $3,5^{\mathrm{bB}}(1,76)$ & $8,9^{\mathrm{A}}(1,24)$ \\
Primavera & $13,0^{\mathrm{a}}(0,97)$ & $3,1^{\mathrm{b}}(0,97)$ & \\
Média &
\end{tabular}

Médias na mesma coluna seguidas de mesma letra maiúscula não diferem entre si $(\mathrm{P}>0,10)$

Médias na mesma linha seguidas de mesma letra minúscula não diferem entre si $(\mathrm{P}>0,10)$

Valores entre parênteses indicam erro padrão da média 
Durante o período de outono/inverno, fase de desenvolvimento reprodutivo da planta, houve efeito de resíduo $(\mathrm{P}=0,0512)$ e estrato $(\mathrm{P}=0,0001)$. A maior proporção de material morto também foi observada no estrato basal, sendo menor no estrato mediano e, por sua vez, menor ainda para o estrato superior (Tabela 20). Para a intensidade de pastejo, foi encontrada maior proporção de material morto quando o resíduo foi mantido a $30 \mathrm{~cm}$ em relação ao resíduo de $50 \mathrm{~cm}$ (9,6 x 5,4\% com EPM=1,46, respectivamente).

Tabela 20. Proporção de material morto (\%) nos estratos basal, mediano e superior da massa de forragem em pré-pastejo de capim-Mombaça submetido a combinações de intervalos entre pastejos (IL) e intensidades de pastejo (altura do resíduo) durante o período de abril de 2001 a setembro de 2001

\begin{tabular}{rc}
\hline Estrato & $\%$ Material morto \\
\hline Basal & $16,5^{\mathrm{A}}(1,79)$ \\
Mediano & $5,8^{\mathrm{B}}(1,79)$ \\
Superior & $0,2^{\mathrm{C}}(1,79)$ \\
Média & 7,5
\end{tabular}

Médias na mesma coluna seguidas de mesma letra maiúscula não diferem entre si $(P>0,10)$ Valores entre parênteses indicam erro padrão da média

\subsection{Material vivo}

Houve efeito de resíduo ( $\mathrm{P}=0,00383)$ e de época do ano $(\mathrm{P}=0,0001)$ no momento da saída dos animais dos piquetes (pós-pastejo). Em relação ao resíduo pode-se notar que a maior porcentagem de material vivo foi obtida nos tratamentos de menor intensidade de pastejo $(50 \mathrm{~cm})$, provavelmente pelo fato de que nessas parcelas foi deixada uma maior massa de forragem remanescente que nos tratamentos de maior intensidade de pastejo $(30 \mathrm{~cm})$. As médias obtidas foram de 70,3 e 66,5 \%, respectivamente, com um erro padrão da média de 1,23.

No verão, época em que as condições climáticas favoreceram uma maior oferta de forragem, decorrente de uma maior produção dos pastos, foi observada a maior 
proporção de material vivo comparativamente as épocas de outono/inverno e primavera (Tabela 21).

Tabela 21. Proporção de material vivo (\% do total) na massa de forragem em pós-pastejo de capim-Mombaça submetido a combinações de intervalos entre pastejos (IL) e intensidades de pastejo (altura do resíduo) durante o período de janeiro de 2001 a fevereiro de 2002

\begin{tabular}{cc}
\hline Época do ano & \%Material Vivo \\
\hline Verão & $74,5^{\mathrm{A}}(1,51)$ \\
Outubro/Inverno & $66,8^{\mathrm{B}}(1,51)$ \\
Primavera & $63,9^{\mathrm{B}}(1,51)$ \\
Média & 68,3
\end{tabular}

Médias na mesma coluna seguidas de mesma letra maiúscula não diferem entre si $(\mathrm{P}>0,10)$

Valores entre parênteses indicam erro padrão da média

Durante o processo de rebrotação, houve efeito de altura ( $\mathrm{P}=0,0649)$, época do ano $(\mathrm{P}=0,0063)$ e da interação resíduo $\mathrm{x}$ altura $\mathrm{x}$ época do ano $(\mathrm{P}=0,0213)$ (Tabela 22).

Nas épocas de verão e primavera foram observadas as maiores proporções de material vivo, sendo a menor porcentagem encontrada no outono/inverno, época em que, devido a fatores climáticos, ocorre acentuada estacionalidade de produção de forragem e intenso processo de florescimento das plantas. $\mathrm{O}$ efeito de interação foi observado durante a primavera, quando houve uma queda de cerca de 2 pontos percentuais na proporção de material vivo nos pastos mantidos com um resíduo de $50 \mathrm{~cm}$ (Tabela 22). No entanto, a variação em proporção de material vivo nos pastos foi de apenas 9,5 pontos percentuais ao longo do ano. 
Tabela 22. Proporção de material vivo (\% do total) na massa de forragem durante a rebrotação de capim-Mombaça com pastejos realizados a 30 e $50 \mathrm{~cm}$ de resíduo durante o período de janeiro de 2001 a fevereiro de 2002

\begin{tabular}{|c|c|c|c|c|}
\hline \multicolumn{5}{|c|}{ Fase de Rebrotação } \\
\hline Resíduo $(\mathrm{cm})$ & +20 & +40 & Média & Média Época \\
\hline \multicolumn{5}{|c|}{ Verão } \\
\hline 30 & $96,7^{\mathrm{aA}}(4,51)$ & $98,5^{\mathrm{aA}}(4,51)$ & $97,6^{\mathrm{A}}(3,19)$ & \\
\hline 50 & $88,7^{\mathrm{aA}}(4,51)$ & $98,6^{\mathrm{aA}}(4,51)$ & $93,7^{\mathrm{A}}(3,19)$ & $95,6^{\mathrm{A}}(2,26)$ \\
\hline Média & $92,7^{\mathrm{a}}(3,19)$ & $98,6^{\mathrm{a}}(3,19)$ & & \\
\hline \multicolumn{5}{|c|}{ Outono/Inverno } \\
\hline 30 & $86,6^{\text {aA }}(4,03)$ & $84,7^{\mathrm{aA}}(4,03)$ & $85,6^{\mathrm{A}}(2,85)$ & \multirow{3}{*}{$86,1^{\mathrm{B}}(2,36)$} \\
\hline 50 & $79,8^{\mathrm{bA}}(4,03)$ & $93,5^{\mathrm{aA}}(6,39)$ & $86,6^{\mathrm{A}}(3,78)$ & \\
\hline Média & $83,2^{\mathrm{a}}(2,85)$ & $89,1^{\mathrm{a}}(3,78)$ & & \\
\hline \multicolumn{5}{|c|}{ Primavera } \\
\hline 30 & $92,6^{\mathrm{aA}}(1,02)$ & $97,4^{\mathrm{aA}}(1,02)$ & $95,0^{\mathrm{A}}(0,72)$ & \multirow{3}{*}{$94,2^{\mathrm{A}}(0,51)$} \\
\hline 50 & $94,8^{\text {aA }}(1,02)$ & $91,9^{\mathrm{bB}}(1,02)$ & $93,3^{\mathrm{B}}(0,72)$ & \\
\hline Média & $93,7^{\mathrm{a}}(0,72)$ & $94,6^{\mathrm{a}}(0,72)$ & & \\
\hline
\end{tabular}

Médias na mesma coluna seguidas de mesma letra maiúscula não diferem entre si $(\mathrm{P}>0,10)$

Médias na mesma linha seguidas de mesma letra minúscula não diferem entre si $(P>0,10)$

Valores entre parênteses indicam erro padrão da média

Em condições de pré-pastejo, foram observados efeitos de resíduo $(\mathrm{P}=0,0338)$, interceptação luminosa $(\mathrm{P}=0,0332)$, estrato $(\mathrm{P}=0,0001)$, época do ano $(\mathrm{P}=0,0001)$ e das interações resíduo x estrato $(\mathrm{P}=0,0697)$, interceptação luminosa $\mathrm{x}$ estrato $(\mathrm{P}=0,0962)$, interceptação luminosa $\mathrm{x}$ época do ano $(\mathrm{P}=0,0043)$ e estrato $\mathrm{x}$ época do ano $(\mathrm{P}=0,0413)$. A maior proporção de material vivo nessa condição foi observada para os tratamentos de menor intensidade de pastejo (resíduo de $50 \mathrm{~cm}$ ) e para o estrato superior (Tabela 23), certamente refletindo a menor mortalidade de perfilhos característica desse tratamento (Uebele, 2002). A interação resíduo x estrato ocorreu pela ausência de diferença na proporção de material vivo entre os resíduos 30 e $50 \mathrm{~cm}$ para o estrato superior do dossel. 
Tabela 23. Proporção de material vivo (\% do total) nos estratos basal e superior da massa de forragem em pré-pastejo de capim-Mombaça com pastejos realizados a 30 e $50 \mathrm{~cm}$ de resíduo durante o período de janeiro de 2001 a fevereiro de 2002

\begin{tabular}{cccc}
\hline \multicolumn{4}{c}{ Estrato } \\
Resíduo $(\mathrm{cm})$ & Basal & Superior & Média \\
\hline 30 & $84,2^{\mathrm{bB}}(1,36)$ & $96,8^{\mathrm{aA}}(1,36)$ & $90,5^{\mathrm{B}}(0,96)$ \\
50 & $89,8^{\mathrm{bA}}(1,36)$ & $97,3^{\mathrm{aA}}(1,36)$ & $93,6^{\mathrm{A}}(0,96)$ \\
Média & $87,0^{\mathrm{b}}(0,96)$ & $97,1^{\mathrm{a}}(0,96)$ & \\
\hline
\end{tabular}

Médias na mesma coluna seguidas de mesma letra maiúscula não diferem entre si $(\mathrm{P}>0,10)$ Médias na mesma linha seguidas de mesma letra minúscula não diferem entre si $(P>0,10)$ Valores entre parênteses indicam erro padrão da média

A Tabela 24 mostra que a proporção de material vivo foi superior para os tratamentos de 95\% IL relativamente aos de 100\% IL. Com relação às épocas do ano, a maior porcentagem de material vivo foi observada no verão, seguida da primavera e do outono/inverno. No verão, os tratamentos de 95 e $100 \%$ IL apresentaram proporções semelhantes de material vivo. Para os tratamentos de $95 \%$ IL a proporção de material vivo não apresentou diferença entre o período de primavera e verão, sendo provavelmente a causa da interação entre interceptação luminosa e época do ano. Regimes de desfolhação mais freqüentes, neste experimento caracterizados pela interceptação luminosa de $95 \%$ IL, propiciaram menores proporções de material morto no início da nova estação de crescimento, indicando o efeito potencial negativo de regimes de desfolhação pouco freqüentes, neste caso representados por $100 \%$ IL, no momento do início dos pastejos, particularmente durante a primavera. 
Tabela 24. Proporção de material vivo (\% do total) na massa de forragem em pré-pastejo de capim-Mombaça com pastejos realizados a 95 e $100 \%$ de interceptação luminosa do dossel forrageiro durante o período de janeiro de 2001 a fevereiro de 2002

\begin{tabular}{cccc}
\hline \multicolumn{4}{c}{ Interceptação Luminosa $(\%)$} \\
Época do ano & 95 & 100 & Média \\
\hline Verão & $95,5^{\mathrm{aA}}(0,87)$ & $95,2^{\mathrm{aA}}(0,87)$ & $95,4^{\mathrm{A}}(0,61)$ \\
Outono/Inverno & $90,7^{\mathrm{aB}}(2,24)$ & $88,6^{\mathrm{aB}}(2,24)$ & $89,6^{\mathrm{B}}(1,58)$ \\
Primavera & $94,6^{\mathrm{aAB}}(1,77)$ & $87,7^{\mathrm{bB}}(1,77)$ & $91,1^{\mathrm{B}}(1,25)$ \\
Média & $93,6^{\mathrm{a}}(0,96)$ & $90,5^{\mathrm{b}}(0,96)$ & \\
\hline
\end{tabular}

Médias na mesma coluna seguidas de mesma letra maiúscula não diferem entre si $(P>0,10)$

Médias na mesma linha seguidas de mesma letra minúscula não diferem entre si $(P>0,10)$

Valores entre parênteses indicam erro padrão da média

$\mathrm{Na}$ Tabela 25 fica clara a diferença entre os estratos da massa de forragem existente na entrada dos animais nos piquetes, com a maior proporção de material vivo sendo observada no estrato superior de forma consistente ao longo de todo o período experimental. A interação estrato $\mathrm{x}$ época do ano foi caracterizada pela ausência de diferença da proporção de material vivo no estrato superior durante os períodos de verão, outono/inverno e primavera. As proporções de material vivo no estrato basal foram consistentemente menores que as proporções do estrato superior independente da época do ano, indicando que a parte superior do dossel, além de se beneficiar da maior disponibilidade de luz incidente pode, através de sombreamento, provocar a morte por senescência de componentes situados na porção inferior da touceira, promovendo a degeneração da estrutura do dossel forrageiro e dificultando a rebrotação subsequente dos pastos nessas condições.

A Tabela 26 mostra que a proporção de material vivo foi mais alta para os tratamentos de $95 \%$ IL. No entanto, o estrato basal apresentou valores inferiores de material vivo para os pastejos iniciados mais tardiamente, ou seja, com $100 \%$ IL, diferença que desapareceu no estrato superior. 
Tabela 25. Proporção de material vivo (\% do total) nos estratos basal e superior da massa de forragem em pré-pastejo de capim-Mombaça submetido a combinações de intervalos entre pastejos (IL) e intensidades de pastejo (altura do resíduo) durante o período de janeiro de 2001 a fevereiro de 2002

\begin{tabular}{cccc}
\hline & \multicolumn{2}{c}{ Estrato } & \\
Época do ano & Basal & Superior & Média \\
\hline Verão & $91,8^{\mathrm{bA}}(0,87)$ & $98,9^{\mathrm{aA}}(0,87)$ & $95,4^{\mathrm{A}}(0,61)$ \\
Outono/Inverno & $83,5^{\mathrm{bB}}(2,24)$ & $95,7^{\mathrm{aAB}}(2,24)$ & $89,6^{\mathrm{B}}(1,58)$ \\
Primavera & $85,7^{\mathrm{bB}}(1,77)$ & $96,5^{\mathrm{aB}}(1,77)$ & $91,1^{\mathrm{B}}(1,25)$ \\
Média & $87,0^{\mathrm{b}}(0,96)$ & $97,1^{\mathrm{a}}(0,96)$ &
\end{tabular}

Médias na mesma coluna seguidas de mesma letra maiúscula não diferem entre si $(P>0,10)$

Médias na mesma linha seguidas de mesma letra minúscula não diferem entre si $(P>0,10)$

Valores entre parênteses indicam erro padrão da média

Tabela 26. Proporção de material vivo (\% do total) nos estratos basal e superior da massa de forragem em pré-pastejo de capim-Mombaça com pastejos realizados a 95 e $100 \%$ de interceptação luminosa do dossel forrageiro durante o período de janeiro de 2001 a fevereiro de 2002

\begin{tabular}{cccc}
\hline \multicolumn{4}{c}{ Interceptação Luminosa $(\%)$} \\
Estrato & 95 & 100 & Média \\
\hline Basal & $89,7^{\mathrm{aB}}(1,34)$ & $84,3^{\mathrm{bB}}(1,36)$ & $87,0^{\mathrm{B}}(0,96)$ \\
Superior & $97,4^{\mathrm{aA}}(1,36)$ & $96,7^{\mathrm{aA}}(1,36)$ & $97,1^{\mathrm{A}}(0,96)$ \\
Média & $93,6^{\mathrm{a}}(0,96)$ & $90,5^{\mathrm{b}}(0,96)$ &
\end{tabular}

Médias na mesma coluna seguidas de mesma letra maiúscula não diferem entre si $(\mathrm{P}>0,10)$ Médias na mesma linha seguidas de mesma letra minúscula não diferem entre si $(P>0,10)$ Valores entre parênteses indicam erro padrão da média

Durante o outono/inverno, época de maior desenvolvimento reprodutivo das plantas, houve efeito de estrato $(\mathrm{P}=0,0001)$ e de resíduo $(\mathrm{P}=0,0954)$. As maiores proporções de material vivo foram encontradas nos estratos medianos e superior (Tabela 27). 
Tabela 27. Proporção de material vivo (\% do total) nos estratos basal, mediano e superior da massa de forragem em pré-pastejo de capim-Mombaça submetido a combinações de intervalos entre pastejos (IL) e intensidades de pastejo (altura do resíduo) durante o período de abril de 2001 a setembro de 2001

\begin{tabular}{cc}
\hline Estrato & $\%$ Material Vivo \\
\hline Basal & $83,5^{\mathrm{C}}(1,86)$ \\
Mediano & $95,0^{\mathrm{B}}(1,86)$ \\
Superior & $99,8^{\mathrm{A}}(1,86)$ \\
Média & 92,8
\end{tabular}

Médias na mesma coluna seguidas de mesma letra maiúscula não diferem entre si $(\mathrm{P}>0,10)$ Valores entre parênteses indicam erro padrão da média

Com relação ao resíduo, os tratamentos de $50 \mathrm{~cm}$ apresentaram consistentemente maiores proporções de material vivo que os tratamentos de $30 \mathrm{~cm}$ (94,6 x 90,9\% com $\mathrm{EPM}=1,52$, respectivamente) apesar da afirmação de Korte \& Harris (1987) de que pastos mantidos sob regime de desfolhação mais intenso teriam maior proporção de material vivo.

\subsection{Folhas}

Foi observado efeito de interceptação luminosa $(\mathrm{P}=0,0001)$, época do ano $(\mathrm{P}=0,0014)$ e da interação resíduo $\mathrm{x}$ interceptação luminosa x época do ano $(\mathrm{P}=0,0033)$ para o componente folhas no momento da saída dos animais dos piquetes (pós-pastejo).

As proporções de folhas foram consistentemente superiores para os tratamentos nos quais os pastejos foram iniciados com 95\% IL em relação àqueles iniciados com 100\%IL (Tabela 28). 
Tabela 28. Proporção de folhas (\% do total) na massa de forragem em pós-pastejo de capim-Mombaça submetido a combinações de intervalos entre pastejos (IL) e intensidades de pastejo (altura do resíduo) durante o período de janeiro de 2001 a fevereiro de 2002

\begin{tabular}{ccccc}
\hline \multicolumn{5}{c}{ Interceptação Luminosa $(\%)$} \\
Resíduo $(\mathrm{cm})$ & 95 & 100 & Média & Média Época \\
\hline \multicolumn{5}{c}{ Verão } \\
30 & $50,5^{\mathrm{aA}}(2,10)$ & $31,1^{\mathrm{bA}}(2,10)$ & $40,8(1,48)$ & \\
50 & $42,0^{\mathrm{aB}}(2,10)$ & $35,4^{\mathrm{bA}}(2,10)$ & $38,7(1,48)$ & $39,8^{\mathrm{B}}(1,05)$ \\
Média & $46,2^{\mathrm{a}}(1,48)$ & $33,3^{\mathrm{b}}(1,48)$ & & \\
\multicolumn{5}{c}{ Outono/Inverno } \\
30 & $39,5^{\mathrm{aA}}(2,10)$ & $34,2^{\mathrm{bA}}(2,10)$ & $36,8(1,48)$ & \\
50 & $42,7^{\mathrm{aA}}(2,10)$ & $29,2^{\mathrm{bB}}(2,10)$ & $35,9(1,48)$ & $36,4^{\mathrm{C}}(1,05)$ \\
Média & $41,1^{\mathrm{a}}(1,48)$ & $31,7^{\mathrm{b}}(1,48)$ & & \\
\multicolumn{5}{c}{ Primavera } \\
30 & $48,9^{\mathrm{aA}}(2,10)$ & $37,2^{\mathrm{bA}}(2,10)$ & $43,0(1,48)$ & \\
50 & $49,0^{\mathrm{aA}}(2,10)$ & $34,3^{\mathrm{bA}}(2,10)$ & $41,7(1,48)$ & $42,3^{\mathrm{A}}(1,05)$ \\
Média & $48,9^{\mathrm{a}}(1,48)$ & $35,8^{\mathrm{b}}(1,48)$ \\
\hline
\end{tabular}

Médias na mesma coluna seguidas de mesma letra maiúscula não diferem entre si $(\mathrm{P}>0,10)$

Médias na mesma linha seguidas de mesma letra minúscula não diferem entre si $(P>0,10)$

Valores entre parênteses indicam erro padrão da média

Com relação à época do ano, as maiores proporções de folhas ocorreram nas épocas de primavera e verão, relativamente ao outono/inverno (Tabela 28), e refletem meramente as variações em estádio de desenvolvimento dos pastos, vegetativo e reprodutivo, respectivamente. Esse comportamento também foi relatado por Santos (1997) quando estudava os cultivares Mombaça e Tanzânia

Não houve efeito de resíduo, mas a interação resíduo x interceptação luminosa $\mathrm{x}$ época do ano foi caracterizada pela diferença entre a proporção de folhas para os resíduos 30 e $50 \mathrm{~cm}$ quando o pastejo foi iniciado a $95 \%$ IL durante o verão. Durante o outono/inverno houve queda acentuada na proporção de folhas para o resíduo de $50 \mathrm{~cm}$ combinado com $100 \%$ IL. Na primavera essa diferença não foi observada para nenhum 
do dois intervalos entre pastejos estudados. As proporções de folhas foram consistentemente menores para o intervalo entre pastejos de $100 \% \mathrm{IL}$ em relação ao de $95 \%$ IL, tanto para os resíduos de 30 como para os de $50 \mathrm{~cm}$, durante todo o período experimental. Teixeira (1998) encontrou 16,3\% de folhas no resíduo pós-pastejo de capim-Tobiatã pastejado com intevalo de 33 dias e período de ocupação de 1 dia.

A análise conjunta dos resultados de proporção de material morto e folhas aponta os efeitos potencialmente negativos que os períodos de descanso mais longos (tratamentos de 100\% IL) e menor intensidade de pastejo (50 $\mathrm{cm}$ de resíduo) podem ter sobre a estrutura do dossel forrageiro, especialmente no início de um novo período de rebrotação.

Durante o período de rebrotação, houve efeito de interceptação luminosa $(\mathrm{P}=0,0164)$, época do ano $(\mathrm{P}=0,0001)$, altura do pasto (fase de rebrotação) $(\mathrm{P}=0,0128)$, interação altura do pasto $\mathrm{x}$ época do ano $(\mathrm{P}=0,0845)$ e resíduo $\mathrm{x}$ interceptação luminosa $\mathrm{x}$ altura do pasto $(\mathrm{P}=0,0942)$. A proporção de folhas durante a rebrotação foi maior para o intervalo entre pastejos de 95\% IL em relação ao de 100\% IL (Tabela 29 ).

Tabela 29. Proporção de folhas (\%) na massa de forragem durante a rebrotação de capim-Mombaça submetido a combinações de intervalos entre pastejos (IL) e intensidades de pastejo (altura do resíduo) durante o período de janeiro de 2001 a fevereiro de 2002

\begin{tabular}{|c|c|c|c|c|}
\hline \multicolumn{5}{|c|}{ Interceptação Luminosa (\%) } \\
\hline Resíduo $(\mathrm{cm})$ & 95 & 100 & Média & Média Altura \\
\hline \multicolumn{5}{|c|}{ Altura +20} \\
\hline 30 & $85,1^{\text {aA }}(2,74)$ & $78,6^{\mathrm{bA}}(2,74)$ & $81,82^{\mathrm{A}}(1,94)$ & \\
\hline 50 & $86,7^{\text {aA }}(2,74)$ & $75,3^{\text {bA }}(2,74)$ & $81,0^{\mathrm{A}}(1,94)$ & $81,4^{\mathrm{B}}(1,37)$ \\
\hline Média & $85,7^{\mathrm{a}}(1,94)$ & $76,9^{\mathrm{b}}(1,94)$ & & \\
\hline \multicolumn{5}{|c|}{ Altura +40} \\
\hline 30 & $90,9^{\mathrm{aA}}(2,74)$ & $84,1^{\text {bA }}(2,74)$ & $87,5^{\mathrm{A}}(1,94)$ & \\
\hline 50 & $85,2^{\text {aA }}(2,74)$ & $88,1^{\text {aA }}(4,09)$ & $86,6^{\mathrm{A}}(2,46)$ & $87,1^{\mathrm{A}}(1,57)$ \\
\hline Média & $88,0^{\mathrm{a}}(1,94)$ & $86,1^{\text {a }}(2,46)$ & & \\
\hline
\end{tabular}

Médias na mesma coluna seguidas de mesma letra maiúscula não diferem entre si $(\mathrm{P}>0,10)$ Médias na mesma linha seguidas de mesma letra minúscula não diferem entre si $(\mathrm{P}>0,10)$ Valores entre parênteses indicam erro padrão da média 
Quanto à época do ano, as maiores proporções de folhas ocorreram nas estações de verão e primavera, relativamente ao outono/inverno (Tabela 30), de forma análoga àquela descrita para a condição de pós-pastejo. Com relação à fase de rebrotamento, a altura de +40 apresentou uma proporção de folhas maior do que a altura +20 (Tabela 30), situação essa característica de um processo mais avançado de rebrotação em que a competição por luz ainda não foi iniciada.

Tabela 30. Proporção de folhas (\%) na massa de forragem durante a rebrotação de capim-Mombaça submetido a combinações de intervalos entre pastejos (IL) e intensidades de pastejo (altura do resíduo) durante o período de janeiro de 2001 a fevereiro de 2002

\begin{tabular}{cccc}
\hline & \multicolumn{2}{c}{ Fase da Rebrotação } & \\
Época do ano & +20 & +40 & Média \\
\hline Verão & $81,8^{\mathrm{bB}}(3,19)$ & $94,1^{\mathrm{aA}}(3,19)$ & $88,0^{\mathrm{A}}(2,25)$ \\
Outono/Inverno & $73,7^{\mathrm{aC}}(2,83)$ & $77,1^{\mathrm{aB}}(3,63)$ & $75,4^{\mathrm{B}}(2,30)$ \\
Primavera & $88,7^{\mathrm{aA}}(1,23)$ & $90,0^{\mathrm{aA}}(1,23)$ & $89,3^{\mathrm{A}}(0,87)$ \\
Média & $81,4^{\mathrm{b}}(1,37)$ & $87,1^{\mathrm{a}}(1,57)$ & \\
\hline
\end{tabular}

Médias na mesma coluna seguidas de mesma letra maiúscula não diferem entre si $(\mathrm{P}>0,10)$

Medias na mesma linha seguidas de mesma letra minúscula não diferem entre si $(\mathrm{P}>0,10)$

Valores entre parênteses indicam erro padrão da média

Em condição de pré-pastejo, houve efeito de resíduo $(\mathrm{P}=0,0028)$, interceptação luminosa $(\mathrm{P}=0,0001)$, época do ano $(\mathrm{P}=0,0001)$ e estrato $(\mathrm{P}=0,0001)$, além da interação resíduo $\mathrm{x}$ interceptação luminosa $\mathrm{x}$ estrato $(\mathrm{P}=0,0387)$ e interceptação luminosa $\mathrm{x}$ época do ano $(\mathrm{P}=0,0611)$. Novamente, as menores proporções de folhas foram observadas durante o período de outono/inverno, época de intenso desenvolvimento reprodutivo dos pastos e de maior ocorrência de material morto nos dosséis forrageiros (Tabela 31). Teixeira (1998) também relatou diminuição na fração de folhas com o avançar da estação de pastejo. Porém, essa queda foi muito mais brusca (72,3\% para $27,5 \%)$ do que as observadas neste experimento devido à falta de controle do resíduo, o que gerou uma queda na relação folha:haste do capim-Tobiatã. Pastos manejados a $95 \%$ IL 
apresentaram consistentemente maior proporção de folhas que aqueles de $100 \%$ IL, independente da época do ano.

Tabela 31. Proporção de folhas (\%) na massa de forragem em pré-pastejo de capimMombaça com pastejos realizados a 95 e $100 \%$ de interceptação luminosa do dossel forrageiro durante o período de janeiro de 2001 a fevereiro de 2002

\begin{tabular}{cccc}
\hline \multicolumn{4}{c}{ Interceptação Luminosa $(\%)$} \\
Época do ano & 95 & 100 & Média \\
\hline Verão & $86,0^{\mathrm{aA}}(1,59)$ & $82,2^{\mathrm{bA}}(1,59)$ & $84,1^{\mathrm{A}}(1,13)$ \\
Outono/Inverno & $73,7^{\mathrm{aB}}(3,22)$ & $63,3^{\mathrm{bC}}(3,22)$ & $68,5^{\mathrm{B}}(2,27)$ \\
Primavera & $89,0^{\mathrm{aA}}(1,44)$ & $77,9^{\mathrm{bB}}(1,44)$ & $83,5^{\mathrm{A}}(1,02)$ \\
Média & $82,9^{\mathrm{a}}(1,13)$ & $74,5^{\mathrm{b}}(1,13)$ & \\
\hline
\end{tabular}

Médias na mesma coluna seguidas de mesma letra maiúscula não diferem entre si $(\mathrm{P}>0,10)$

Médias na mesma linha seguidas de mesma letra minúscula não diferem entre si $(\mathrm{P}>0,10)$

Valores entre parênteses indicam erro padrão da média

Em termos de resíduo, as maiores proporções de folhas foram verificadas para os tratamentos de resíduo $50 \mathrm{~cm}$ no estrato basal, conseqüência direta da maior frequência de desfolhação a que foi submetido o tratamento 50/95 (resíduo/IL). Já para o estrato superior, não houve diferença entre os resíduos estudados (Tabela 32). Os tratamentos de intervalo entre pastejos de 95\% IL geraram as maiores proporções de folhas em relação aos de $100 \%$ IL no estrato basal, porém essa diferença não existiu no estrato superior. As maiores proporções de folhas ocorreram consistentemente no estrato superior, sendo o estrato basal o mais sensível à variação de todos os componentes morfológicos estudados, confirmando a importância de proporcionar a oportunidade de seleção aos animais como sugerido por diversos autores (Hodgson, 1990; Veiga et al., 1985). A interação resíduo $\mathrm{x}$ interceptação luminosa $\mathrm{x}$ estrato foi caracterizada pela maior proporção de folhas existente nos tratamentos de resíduo $50 \mathrm{~cm}$ para o estrato basal passar a ocorrer para os tratamentos de resíduo $30 \mathrm{~cm}$ no estrato superior, revelando que em termos de início de rebrotação o resíduo mais alto pode ser mais favorável. No entanto, ao longo do processo de rebrotação, essa vantagem passa a ser 
compensada pela menor participação de folhas no dossel forrageiro a ser ofertado como alimento para os animais, fato também verificado por Teixeira (1998), que sugeriu que o baixo aproveitamento e elevada perda da forragem em pastos de capim-Tobiatã poderiam ter sido minimizados se o resíduo pós-pastejo fosse mantido mais baixo.

Tabela 32. Proporção de folhas (\%) na massa de forragem em pré-pastejo de capimMombaça submetido a combinações de intervalos entre pastejos (IL) e intensidades de pastejo (altura do resíduo) durante o período de janeiro de 2001 a fevereiro de 2002

\begin{tabular}{|c|c|c|c|c|}
\hline \multirow[b]{2}{*}{ Resíduo (cm) } & \multicolumn{2}{|c|}{ Interceptação Luminosa (\%) } & \multirow[b]{2}{*}{ Média } & \multirow[b]{2}{*}{ Média Estrato } \\
\hline & 95 & 100 & & \\
\hline \multicolumn{5}{|c|}{ Estrato Basal } \\
\hline 30 & $70,7^{\mathrm{aB}}(2,24)$ & $49,8^{\mathrm{bB}}(2,24)$ & $60,2^{\mathrm{B}}(1,59)$ & \\
\hline 50 & $80,2^{\mathrm{aA}}(2,24)$ & $68,0^{\mathrm{bA}}(2,24)$ & $74,1^{\mathrm{A}}(1,59)$ & $67,2^{\mathrm{B}}(1,12)$ \\
\hline Média & $75,4^{\mathrm{a}}(1,59)$ & $58,9^{\mathrm{b}}(1,59)$ & & \\
\hline \multicolumn{5}{|c|}{ Estrato Superior } \\
\hline 30 & $90,6^{\mathrm{aA}}(2,24)$ & $93,0^{\mathrm{aA}}(2,24)$ & $91,8^{\mathrm{A}}(1,59)$ & \\
\hline 50 & $90,2^{\mathrm{aA}}(2,24)$ & $87,2^{\mathrm{aB}}(2,24)$ & $88,7^{\mathrm{A}}(1,59)$ & $90,2^{\mathrm{A}}(1,12)$ \\
\hline Média & $90,4^{\mathrm{a}}(1,59)$ & $90,1^{\mathrm{a}}(1,59)$ & & \\
\hline
\end{tabular}

Médias na mesma coluna seguidas de mesma letra maiúscula não diferem entre si $(\mathrm{P}>0,10)$

Médias na mesma linha seguidas de mesma letra minúscula não diferem entre si $(P>0,10)$

Valores entre parênteses indicam erro padrão da média

Durante o período de desenvolvimento reprodutivo das plantas (outono/inverno), houve efeito de interceptação luminosa $(\mathrm{P}=0,0028)$, estrato $(\mathrm{P}=0,0001)$ e da interação resíduo $\mathrm{x}$ interceptação luminosa $(\mathrm{P}=0,0654)$ e resíduo $\mathrm{x}$ estrato $(\mathrm{P}=0,0517)$. A proporção de folhas foi maior cerca de 11 unidades percentuais para o intervalo entre pastejos de 95\% IL em relação ao de 100\%IL (Tabela 33). O dossel, quando dividido em três estratos, revelou um aumento crescente na proporção de folhas do estrato basal para o estrato superior (Tabela 34). 
Tabela 33. Proporção de folhas (\%) na massa de forragem em pré-pastejo de capimMombaça submetido a combinações de intervalos entre pastejos (IL) e intensidades de pastejo (altura do resíduo) durante o período de abril de 2001 a setembro de 2001

\begin{tabular}{cccc}
\hline & \multicolumn{2}{c}{ Interceptação Luminosa $(\%)$} & Média \\
\hline Resíduo $(\mathrm{cm})$ & 95 & 100 & $71,6^{\mathrm{A}}(2,33)$ \\
50 & $80,1^{\mathrm{aA}}(3,30)$ & $63,1^{\mathrm{bA}}(3,30)$ & $70,1^{\mathrm{A}}(2,33)$ \\
Média & $72,3^{\mathrm{aB}}(3,30)$ & $67,9^{\mathrm{aA}}(3,30)$ &
\end{tabular}

Médias na mesma coluna seguidas de mesma letra maiúscula não diferem entre si $(\mathrm{P}>0,10)$

Médias na mesma linha seguidas de mesma letra minúscula não diferem entre si $(\mathrm{P}>0,10)$

Valores entre parênteses indicam erro padrão da média

Tabela 34. Proporção de folhas (\%) nos estratos basal, mediano e superior da massa de forragem em pré-pastejo de capim-Mombaça com pastejos realizados a $30 \mathrm{e}$ $50 \mathrm{~cm}$ de resíduo durante o período de abril de 2001 a setembro de 2001

\begin{tabular}{|c|c|c|c|}
\hline \multicolumn{4}{|c|}{ Resíduo (cm) } \\
\hline Estrato & 30 & 50 & Média \\
\hline Basal & $52,6^{\mathrm{bB}}(4,04)$ & $62,7^{\mathrm{aB}}(4,04)$ & $57,7^{\mathrm{B}}(2,86)$ \\
\hline Mediano & $79,0^{\mathrm{aA}}(4,04)$ & $74,0^{\mathrm{aA}}(4,04)$ & $76,5^{\mathrm{A}}(2,86)$ \\
\hline Superior & $83,2^{\mathrm{aA}}(4,04)$ & $73,7^{\mathrm{bA}}(4,04)$ & $78,4^{\mathrm{A}}(2,86)$ \\
\hline Média & $71,6^{\mathrm{a}}(2,33)$ & $70,1^{a}(2,33)$ & \\
\hline
\end{tabular}

Médias na mesma coluna seguidas de mesma letra maiúscula não diferem entre si $(\mathrm{P}>0,10)$

Médias na mesma linha seguidas de mesma letra minúscula não diferem entre si $(P>0,10)$

Valores entre parênteses indicam erro padrão da média

\subsection{Hastes}

$\mathrm{Na}$ condição de pós-pastejo, houve efeito de resíduo $(\mathrm{P}=0,0167)$, interceptação luminosa $(\mathrm{P}=0,0001)$ e época do ano $(\mathrm{P}=0,0001)$, além da interação resíduo $\mathrm{x}$ interceptação luminosa $\mathrm{x}$ época do ano $(\mathrm{P}=0,0962)$. A proporção de hastes foi maior quando a intensidade de pastejo foi menor (resíduo de $50 \mathrm{~cm}$ ) no outono/inverno devido, talvez, à menor mortalidade de perfilhos (Uebele, 2002), que pode ter favorecido o alongamento das hastes (Tabela 35). No entanto, mesmo para o pastejo mais leniente, os 
valores médios de haste deste experimento foram praticamente metade daqueles encontrados por Teixeira (1998) quando avaliou o capim-Tobiatã.

Tabela 35. Proporção de hastes (\% do total) na massa de forragem em pós-pastejo de capim-Mombaça submetido a combinações de intervalos entre pastejos (IL) e intensidades de pastejo (altura do resíduo) durante o período de janeiro de 2001 a fevereiro de 2002

\begin{tabular}{ccccc}
\hline \multicolumn{5}{c}{ Interceptação Luminosa $(\%)$} \\
Resíduo $(\mathrm{cm})$ & 95 & 100 & Média & Média Época \\
\hline \multicolumn{5}{c}{ Verão } \\
30 & $21,8^{\mathrm{bB}}(3,00)$ & $42,7^{\mathrm{aA}}(3,00)$ & $32,2^{\mathrm{A}}(2,13)$ & \\
50 & $32,7^{\mathrm{aA}}(3,00)$ & $38,6^{\mathrm{aA}}(3,00)$ & $35,6^{\mathrm{A}}(2,13)$ & $33,9^{\mathrm{A}}(1,50)$ \\
Média & $27,2^{\mathrm{b}}(2,13)$ & $40,6^{\mathrm{a}}(2,13)$ & & \\
\multicolumn{5}{c}{ Outono/Inverno } \\
30 & $20,8^{\mathrm{bA}}(3,00)$ & $30,1^{\mathrm{aA}}(3,00)$ & $25,5^{\mathrm{B}}(2,12)$ & \\
50 & $26,1^{\mathrm{bA}}(3,00)$ & $36,9^{\mathrm{aA}}(3,00)$ & $31,5^{\mathrm{A}}(2,13)$ & $28,5^{\mathrm{B}}(1,50)$ \\
Média & $23,5^{\mathrm{b}}(2,13)$ & $33,5^{\mathrm{a}}(2,13)$ & & \\
30 & $17,2^{\mathrm{aA}}(3,00)$ & $22,1^{\mathrm{aA}}(3,00)$ & $19,6^{\mathrm{A}}(2,13)$ & \\
50 & $20,1^{\mathrm{aA}}(3,00)$ & $26,5^{\mathrm{aA}}(3,00)$ & $23,3^{\mathrm{A}}(2,13)$ & $21,5^{\mathrm{C}}(1,50)$ \\
Média & $18,7^{\mathrm{b}}(2,13)$ & $24,3^{\mathrm{a}}(2,13)$ & & \\
\hline
\end{tabular}

Médias na mesma coluna seguidas de mesma letra maiúscula não diferem entre si $(\mathrm{P}>0,10)$

Médias na mesma linha seguidas de mesma letra minúscula não diferem entre si $(P>0,10)$

Valores entre parênteses indicam erro padrão da média

Já no intervalo entre pastejos de $95 \%$ IL, a proporção de hastes foi cerca de 10 unidades percentuais menor em relação ao intervalo de 100\% IL, situação em que os pastejos ocorreram com uma menor freqüência, possivelmente resultando no alongamento de hastes. Essa maior proporção de hastes nos tratamentos de 100\% IL é típica de pastos onde as plantas lançam mão do alongamento da haste em busca de ambiente luminoso de melhor qualidade para a emissão de novas folhas, podendo gerar conseqüências negativas para os animais que delas se alimentam (Tabela 35). A 
proporção de hastes diminuiu do verão para a primavera, sendo o maior valor constatado durante o verão $(33,9 \%)$ e o menor durante a primavera $(21,5 \%)$ (Tabela 35$)$.

Durante a rebrotação, houve efeito de interceptação luminosa $(\mathrm{P}=0,0033)$, altura do pasto (fase de rebrotação) $(\mathrm{P}=0,0513)$, época do ano $(\mathrm{P}=0,0040)$ e das interações resíduo $\mathrm{x}$ interceptação luminosa $\mathrm{x}$ época do ano $(\mathrm{P}=0,0153)$ e resíduo $\mathrm{x}$ altura de rebrotação $\mathrm{x}$ época do ano $(\mathrm{P}=0,0347)$. Pastos com pastejos iniciados com $100 \%$ IL apresentaram as maiores proporções de haste durante a rebrotação que aqueles de $95 \%$ IL no outono/inverno e primavera (Tabela 36). Em termos de época do ano, as maiores proporções de haste foram constatadas durante as épocas de verão e outono/inverno, épocas típicas de indução e desenvolvimento reprodutivo de plantas de capim-Mombaça.

A interação resíduo $\mathrm{x}$ interceptação luminosa $\mathrm{x}$ época do ano foi caracterizada pela maior proporção de hastes no tratamento de resíduo $50 \mathrm{~cm}$ e $95 \%$ IL durante o verão. Exceção feita a esse único caso, nas demais comparações os tratamentos de 100\% IL apresentaram, consistentemente, as maiores proporções de hastes durante todo o período experimental. Provavelmente o resíduo mais alto favoreceu a indução floral dos pastos utilizados segundo a maior freqüência de pastejo (95\% IL) durante o verão, fato este corroborado pelos resultados de Uebele (2002), que revelaram que a maior intensidade de desfolhação exerceu um efeito relativo maior sobre a mortalidade de perfilhos comparativamente à desfolhação mais freqüente (cerca de 2,25 vezes). Esse fato aponta a época de verão como chave no controle da estrutura dos pastos (relação vivo:morto e haste:folha) e do desenvolvimento reprodutivo das plantas. Os dados revelam o forte efeito controlador da intensidade de pastejo sobre o desenvolvimento de hastes nos pastos e o efeito otimizador que a frequência de pastejos tem sobre a intensidade de desfolhação nessas circunstâncias. 
Tabela 36. Proporção de hastes (\%) na massa de forragem durante a rebrotação de capim-Mombaça submetido a combinações de intervalos entre pastejos (IL) e intensidades de pastejo (altura do resíduo) durante o período de janeiro de 2001 a fevereiro de 2002

\begin{tabular}{ccccc}
\hline \multicolumn{5}{c}{ Interceptação Luminosa (\%) } \\
Resíduo (cm) & 95 & 100 & Média & Média Época \\
\hline \multicolumn{5}{c}{ Verão } \\
30 & $4,2^{\mathrm{bB}}(1,42)$ & $9,6^{\mathrm{aA}}(1,42)$ & $6,9^{\mathrm{A}}(1,01)$ & \\
50 & $10,5^{\mathrm{aA}}(1,42)$ & $6,4^{\mathrm{bA}}(1,42)$ & $8,4^{\mathrm{A}}(1,01)$ & $7,7^{\mathrm{A}}(0,71)$ \\
Média & $7,4^{\mathrm{a}}(1,01)$ & $8,0^{\mathrm{a}}(1,01)$ & \\
\multicolumn{5}{c}{ Outono/Inverno } \\
30 & $4,8^{\mathrm{bA}}(1,42)$ & $8,6^{\mathrm{aA}}(1,42)$ & $6,7^{\mathrm{A}}(1,01)$ & \\
50 & $4,3^{\mathrm{bA}}(1,42)$ & $8,9^{\mathrm{aA}}(2,14)$ & $6,6^{\mathrm{A}}(1,28)$ & $6,6^{\mathrm{A}}(0,82)$ \\
Média & $4,5^{\mathrm{b}}(1,01)$ & $8,8^{\mathrm{a}}(1,28)$ & \\
50 & $2,6^{\mathrm{bA}}(1,42)$ & $9,9^{\mathrm{aA}}(1,42)$ & $6,3^{\mathrm{A}}(1,01)$ & \\
50 & $0,9^{\mathrm{bA}}(1,42)$ & $5,8^{\mathrm{aB}}(1,42)$ & $3,4^{\mathrm{B}}(1,01)$ & $4,8^{\mathrm{B}}(0,71)$ \\
Média & $1,8^{\mathrm{b}}(1,01)$ & $7,9^{\mathrm{a}}(1,01)$ & \\
\hline
\end{tabular}

Médias na mesma coluna seguidas de mesma letra maiúscula não diferem entre si $(\mathrm{P}>0,10)$

Médias na mesma linha seguidas de mesma letra minúscula não diferem entre si $(P>0,10)$

Valores entre parênteses indicam erro padrão da média

Quanto à interação resíduo $\mathrm{x}$ altura de rebrotação $\mathrm{x}$ época do ano, esta foi caracterizada pela menor proporção de hastes nos tratamentos de resíduo $50 \mathrm{~cm}$ após os primeiros $20 \mathrm{~cm}$ de rebrotação durante o outono/inverno e primavera (Tabela 37). De uma forma geral, a proporção de hastes diminuiu ao longo da rebrotação $(+20$ e +40 $\mathrm{cm}$ ), com os maiores valores registrados durante o verão e outono/inverno. 
Tabela 37. Proporção de hastes (\%) na massa de forragem durante a rebrotação de capim-Mombaça com pastejos realizados a 30 e $50 \mathrm{~cm}$ de resíduo durante o período de janeiro de 2001 a fevereiro de 2002

\begin{tabular}{|c|c|c|c|c|}
\hline \multicolumn{5}{|c|}{ Fase de Rebrotação } \\
\hline Residuo (cm) & +20 & +40 & Média & Média Época \\
\hline \multicolumn{5}{|c|}{ Verão } \\
\hline 30 & $10,6^{\mathrm{aA}}(1,42)$ & $3,2^{\mathrm{bA}}(1,42)$ & $6,9^{\mathrm{A}}(1,01)$ & \\
\hline 50 & $11,2^{\mathrm{aA}}(1,42)$ & $5,6^{\mathrm{bA}}(1,42)$ & $8,4^{\mathrm{A}}(1,01)$ & $7,7^{\mathrm{A}}(0,71)$ \\
\hline Média & $10,9^{\mathrm{a}}(1,01)$ & $4,4^{\mathrm{b}}(1,01)$ & & \\
\hline \multicolumn{5}{|c|}{ Outono/Inverno } \\
\hline 30 & $9,5^{\mathrm{aA}}(1,42)$ & $3,9^{\mathrm{bB}}(1,42)$ & $6,7^{\mathrm{A}}(1,01)$ & \\
\hline 50 & $3,8^{\mathrm{bB}}(1,42)$ & $9,3^{\mathrm{aA}}(2,14)$ & $6,6^{\mathrm{A}}(1,01)$ & $6,6^{\mathrm{A}}(0,82)$ \\
\hline Média & $6,7^{\mathrm{a}}(1,01)$ & $6,6^{\mathrm{a}}(1,28)$ & & \\
\hline \multicolumn{5}{|c|}{ Primavera } \\
\hline 30 & $7,4^{\mathrm{aA}}(1,42)$ & $5,2^{\mathrm{aA}}(1,42)$ & $6,3^{\mathrm{A}}(1,01)$ & \\
\hline 50 & $2,6^{\mathrm{aB}}(1,42)$ & $4,1^{\text {aA }}(1,42)$ & $3,4^{\mathrm{B}}(1,01)$ & $4,8^{\mathrm{B}}(0,71)$ \\
\hline Média & $5,0^{\mathrm{a}}(1,01)$ & $4,7^{\mathrm{a}}(1,01)$ & & \\
\hline
\end{tabular}

Médias na mesma coluna seguidas de mesma letra maiúscula não diferem entre si $(\mathrm{P}>0,10)$

Médias na mesma linha seguidas de mesma letra minúscula não diferem entre si $(\mathrm{P}>0,10)$

Valores entre parênteses indicam erro padrão da média

Para a condição de pré-pastejo, houve efeito de resíduo $(\mathrm{P}=0,0001)$, interceptação luminosa $(\mathrm{P}=0,0001)$, estrato $(\mathrm{P}=0,0001)$ e época do ano $(\mathrm{P}=0,0001)$. Foram detectadas também as interações resíduo x estrato $(\mathrm{P}=0,0006)$, interceptação luminosa $\mathrm{x}$ estrato $(\mathrm{P}=0,0001)$ e interceptação luminosa $\mathrm{x}$ época do ano $(\mathrm{P}=0,0097)$. As maiores proporções de hastes foram observadas para os tratamentos de resíduo $30 \mathrm{~cm}$ relativamente aos de resíduo $50 \mathrm{~cm}$ (Tabela 38), provavelmente em função dos pastejos iniciados com 100\% IL que, quando associados com o resíduo de $30 \mathrm{~cm}$, resultaram nos maiores períodos de descanso entre pastejos (Tabela 3). $\mathrm{O}$ estrato basal do pasto apresentou as maiores proporções de hastes, sendo a interação resíduo x estrato caracterizada pela grande redução da proporção de hastes no estrato basal dos pastos quando o resíduo passou de 30 para $50 \mathrm{~cm}$. Isso provavelmente ocorreu como conseqüência da menor mortalidade de 
perfilhos e hastes reprodutivas nos tratamentos de resíduo $50 \mathrm{~cm}$, particularmente durante o verão, além da maior proporção de folhas sob aquelas condições. No estrato superior do dossel existiu praticamente apenas folhas, sendo a proporção de hastes de apenas $3,5 \%$.

Tabela 38. Proporção de hastes (\%) nos estratos basal e superior da massa de forragem em pré-pastejo de capim-Mombaça com pastejos realizados a 30 e $50 \mathrm{~cm}$ de resíduo durante o período de janeiro de 2001 a fevereiro de 2002

\begin{tabular}{cccc}
\hline & & Estrato & \\
Resíduo $(\mathrm{cm})$ & Basal & Superior & Média \\
\hline 30 & $23,9^{\mathrm{aA}}(1,09)$ & $4,0^{\mathrm{bA}}(1,09)$ & $14,0^{\mathrm{A}}(0,77)$ \\
50 & $14,2^{\mathrm{aB}}(1,09)$ & $3,1^{\mathrm{bA}}(1,09)$ & $8,7^{\mathrm{B}}(0,77)$ \\
Média & $19,1^{\mathrm{a}}(0,77)$ & $3,6^{\mathrm{b}}(0,77)$ & \\
\hline
\end{tabular}

Médias na mesma coluna seguidas de mesma letra maiúscula não diferem entre si $(\mathrm{P}>0,10)$

Médias na mesma linha seguidas de mesma letra minúscula não diferem entre si $(P>0,10)$

Valores entre parênteses indicam erro padrão da média

Quanto ao regime de interceptação luminosa, as maiores proporções de hastes foram observadas nos tratamentos de 100\% IL relativamente àqueles de 95\% IL (Tabela 39). Neste caso também a interação interceptação luminosa x estrato foi conseqüência da grande redução na porcentagem de hastes do estrato basal para o superior, redução essa proporcionalmente maior para os tratamentos de 100\% IL em relação aos de 95\% IL. Os resultados revelam que pastejos mais freqüentes resultaram nas menores proporções de hastes em ambos os estratos, demonstrando o efeito otimizador de controle de desenvolvimento desse componente morfológico relativamente à intensidade de pastejo (resíduo de $30 \mathrm{~cm}$ ). Revelam, também, que a associação de pastejo com resíduo de 50 cm e período de descanso longo (100\% IL) favorece o desenvolvimento de hastes e degeneração da estrutura dos dosséis forrageiros em ambos os estratos, basal (comprometendo o vigor de rebrotação dos pastos) e superior (comprometendo o valor nutritivo da forragem ofertada para os animais em pastejo). 
Tabela 39. Proporção de hastes (\%) nos estratos basal e superior da massa de forragem em pré-pastejo de capim-Mombaça com pstejos realizados a 95 e $100 \%$ de interceptação luminosa do dossel forrageiro durante o período de janeiro de 2001 a fevereiro de 2002

\begin{tabular}{cccc}
\hline & \multicolumn{4}{c}{ Interceptação Luminosa (\%) } \\
Estrato & 95 & 100 & Média \\
\hline Basal & $12,8^{\mathrm{bA}}(1,09)$ & $25,3^{\mathrm{aA}}(1,09)$ & $19,1^{\mathrm{A}}(0,77)$ \\
Superior & $3,1^{\mathrm{aB}}(1,09)$ & $4,0^{\mathrm{aB}}(1,09)$ & $3,6^{\mathrm{B}}(0,77)$ \\
Média & $8,0^{\mathrm{b}}(0,77)$ & $14,7^{\mathrm{a}}(0,77)$ & \\
\hline
\end{tabular}

Médias na mesma coluna seguidas de mesma letra maiúscula não diferem entre si $(P>0,10)$

Médias na mesma linha seguidas de mesma letra minúscula não diferem entre si $(P>0,10)$

Valores entre parênteses indicam erro padrão da média

Com relação à época do ano, as menores proporções de hastes foram constatadas na primavera, imediatamente após os períodos de indução floral (verão) e florescimento intenso (outono/inverno) (Tabela 40), seqüência natural de ocorrência dos eventos de produção, acúmulo e redução da quantidade e proporção de hastes. A interação interceptação luminosa $\mathrm{x}$ época do ano foi caracterizada pela redução da proporção de hastes do verão para o outono/inverno nos tratamentos de $95 \%$ IL e pelo aumento correspondente nos tratamentos de $100 \%$ IL, revelando o controle efetivo do desenvolvimento de hastes reprodutivas durante o verão pelo uso de uma maior freqüência $(95 \% \mathrm{IL})$ relativamente à menor freqüência de pastejos $(100 \% \mathrm{IL})$. O maior intervalo entre pastejos nessas circunstâncias resultou em florescimento intenso durante o período de outono/inverno e em efeitos potenciais negativos sobre a estrutura do dossel, particularmente resíduo, no início da primavera, época de novo ciclo de crescimento e produção das plantas.

Durante o período de outono/inverno, época de intenso desenvolvimento reprodutivo das plantas, houve efeito de interceptação luminosa $(\mathrm{P}=0,0001)$, estrato $(\mathrm{P}=0,0001)$ e da interação interceptação luminosa $\mathrm{x}$ estrato $(\mathrm{P}=0,0014)$. Os tratamentos de $100 \%$ IL apresentaram as maiores proporções de hastes na massa de forragem em pré-pastejo, sendo que essa proporção foi decrescente do estrato basal para o superior (Tabela 41). A interação interceptação luminosa $\mathrm{x}$ estrato foi devida à maior redução 
relativa na proporção de hastes do estrato basal para o superior nos tratamentos de $100 \%$ IL comparativamente àqueles de $95 \%$ IL. Novamente, foi aparente o efeito negativo do período de descanso mais longo sobre a estrutura do dossel e sua composição morfológica, características essas que podem ter compensado os benefícios provenientes da maior massa de forragem existente sob aquelas circunstâncias.

Tabela 40. Proporção de hastes (\%) na massa de forragem em pré-pastejo de capimMombaça realizados a 95 e $100 \%$ de interceptação luminosa do dossel forrageiro durante o período de janeiro de 2001 a fevereiro de 2002

\begin{tabular}{cccc}
\hline & \multicolumn{4}{c}{ Interceptação Luminosa $(\%)$} \\
Época do ano & 95 & 100 & Média \\
\hline Verão & $9,5^{\mathrm{bA}}(1,21)$ & $13,0^{\mathrm{aB}}(1,21)$ & $11,3^{\mathrm{B}}(0,86)$ \\
Outono/Inverno & $8,8^{\mathrm{b} \mathrm{AB}}(1,79)$ & $21,3^{\mathrm{aA}}(1,79)$ & $15,1^{\mathrm{A}}(1,26)$ \\
Primavera & $5,5^{\mathrm{bB}}(1,41)$ & $9,8^{\mathrm{aB}}(1,41)$ & $7,6^{\mathrm{C}}(1,00)$ \\
Média & $8,0^{\mathrm{b}}(0,77)$ & $14,7^{\mathrm{a}}(0,77)$ & \\
\hline
\end{tabular}

Médias na mesma coluna seguidas de mesma letra maiúscula não diferem entre si $(\mathrm{P}>0,10)$

Médias na mesma linha seguidas de mesma letra minúscula não diferem entre si $(P>0,10)$

Valores entre parênteses indicam erro padrão da média

Tabela 41. Proporção de hastes (\%) nos estratos basal, mediano e superior da massa de forragem em pré-pastejo de capim-Mombaça realizados a 95 e $100 \%$ de interceptação luminosa do dossel forrageiro durante o período de abril de 2001 a setembro de 2001

\begin{tabular}{cccc}
\hline \multicolumn{4}{c}{ Interceptação Luminosa $(\%)$} \\
Estrato & 95 & 100 & Média \\
\hline Basal & $13,2^{\mathrm{bA}}(2,62)$ & $34,0^{\mathrm{aA}}(2,62)$ & $23,6^{\mathrm{A}}(1,85)$ \\
Mediano & $5,0^{\mathrm{bB}}(2,62)$ & $14,8^{\mathrm{aB}}(2,62)$ & $9,9^{\mathrm{B}}(1,85)$ \\
Superior & $0,3^{\mathrm{aB}}(2,62)$ & $0,0^{\mathrm{aC}}(2,62)$ & $0,2^{\mathrm{C}}(1,85)$ \\
Média & $6,2^{\mathrm{b}}(1,51)$ & $16,3^{\mathrm{a}}(1,51)$ & \\
\hline
\end{tabular}

Médias na mesma coluna seguidas de mesma letra maiúscula não diferem entre si $(\mathrm{P}>0,10)$

Médias na mesma linha seguidas de mesma letra minúscula não diferem entre si $(\mathrm{P}>0,10)$

Valores entre parênteses indicam erro padrão da média 


\subsection{Hastes florescidas}

Para o componente haste florescida, houve efeito apenas de época do ano $(\mathrm{P}=0,0072)$ na condição de pós-pastejo (Tabela 42). Durante a rebrotação houve efeito de época do ano $(\mathrm{P}=0,0030)$ (Tabela 43) e da interação resíduo x interceptação luminosa $\mathrm{x}$ altura do pasto $(\mathrm{P}=0,0619)$ Essa interação ocorreu porque houve um aumento na proporção de haste florescida na altura +40 para o tratamento 50/95 em relação aos demais tratamentos (Tabela 44). A ocorrência de hastes visualmente reprodutivas foi notada somente na época de outono/inverno, período de desenvolvimento reprodutivo das plantas. $\mathrm{O}$ valor absoluto das médias apresentadas não deve ser considerado como referência, uma vez que apenas os perfilhos com inflorescências visíveis foram contabilizados, não tendo sido executada forma alguma de dissecação das plantas. $\mathrm{O}$ que é importante são as diferenças relativas entre as épocas do ano representadas por esses valores.

Tabela 42. Proporção de hastes florescidas (\%) na massa de forragem em pós-pastejo de capim-Mombaça submetido a combinações de intervalos entre pastejos (IL) e intensidades de pastejo (altura do resíduo) durante o período de janeiro de 2001 a fevereiro de 2002

\begin{tabular}{cc}
\hline Época do ano & $\%$ Hastes Florescidas \\
\hline Verão & $0,0^{\mathrm{B}}(0,29)$ \\
Outono/Inverno & $1,2^{\mathrm{A}}(0,29)$ \\
Primavera & $0,0^{\mathrm{B}}(0,29)$ \\
Média & 0,4
\end{tabular}

Médias na mesma coluna seguidas de mesma letra maiúscula não diferem entre si $(\mathrm{P}>0,10)$ Valores entre parênteses indicam erro padrão da média 
Tabela 43. Proporção de hastes florescidas (\%) na massa de forragem durante a rebrotação de capim-Mombaça submetido a combinações de intervalos entre pastejos (IL) e intensidades de pastejo (altura do resíduo) durante o período de janeiro de 2001 a fevereiro de 2002

\begin{tabular}{cc}
\hline Época do ano & \% Hastes Florescidas \\
\hline Verão & $0,0^{\mathrm{B}}(0,78)$ \\
Outono/Inverno & $4,5^{\mathrm{A}}(0,91)$ \\
Primavera & $0,0^{\mathrm{B}}(0,78)$ \\
Média & 1,5
\end{tabular}

Médias na mesma coluna seguidas de mesma letra maiúscula não diferem entre si $(P>0,10)$ Valores entre parênteses indicam erro padrão da média

Tabela 44. Proporção de hastes florescidas (\%) na massa de forragem durante a rebrotação de capim-Mombaça submetido a combinações de intervalos entre pastejos (IL) e intensidades de pastejo (altura do resíduo) durante o período de janeiro de 2001 a fevereiro de 2002

\begin{tabular}{ccccc}
\hline \multicolumn{5}{c}{ Interceptação Luminosa (\%) } \\
Resíduo (cm) & 95 & 100 & Média & Média Altura \\
\hline \multicolumn{7}{c}{ Altura +20} \\
30 & $1,69^{\mathrm{aA}}(1,15)$ & $0,29^{\mathrm{aA}}(1,15)$ & $0,99^{\mathrm{A}}(0,81)$ & \\
50 & $1,21^{\mathrm{aA}}(1,15)$ & $0,51^{\mathrm{aA}}(1,15)$ & $0,86^{\mathrm{A}}(0,81)$ & $0,9^{\mathrm{A}}(0,58)$ \\
Média & $1,4^{\mathrm{a}}(0,81)$ & $0,4^{\mathrm{a}}(0.81)$ & & \\
\multicolumn{7}{c}{ Altura +40} \\
30 & $0,63^{\mathrm{aB}}(1,15)$ & $3,25^{\mathrm{aA}}(1,15)$ & $1,94^{\mathrm{A}}(0,81)$ & \\
50 & $4,1^{\mathrm{aA}}(1,15)$ & $0,51^{\mathrm{bA}}(1,69)$ & $2,28^{\mathrm{A}}(1,02)$ & $2,1^{\mathrm{A}}(0,65)$ \\
Média & $2,3^{\mathrm{a}}(0,81)$ & $1,9^{\mathrm{a}}(1,02)$ & & \\
\hline
\end{tabular}

Médias na mesma coluna seguidas de mesma letra maiúscula não diferem entre si $(\mathrm{P}>0,10)$

Médias na mesma linha seguidas de mesma letra minúscula não diferem entre si $(P>0,10)$

Valores entre parênteses indicam erro padrão da média

Em condições de pré-pastejo, houve efeito de resíduo $(\mathrm{P}=0,0701)$, estrato $(\mathrm{P}=0,0084)$, época do ano $(\mathrm{P}=0,0001)$ e da interação estrato $\mathrm{x}$ época do ano $(\mathrm{P}=0,0007) \mathrm{e}$ resíduo x época do ano $(\mathrm{P}=0,0337)$. A maior proporção de hastes florescidas ocorreu no estrato superior (Tabela 45), característica típica de ocorrência desse componente morfológico no dossel e da forma como os dados foram coletados (inflorescências 
visíveis), e nos tratamentos de $50 \mathrm{~cm}$ de resíduo (Tabela 46). Nessa condição também a ocorrência de hastes reprodutivas foi notada apenas na época de outono/inverno. A interação estrato x época do ano foi caracterizada pela desproporcionalidade acentuada no aumento de hastes florescidas do estrato basal para o superior durante a época de outono/inverno. Esse fato aponta para o efeito negativo do processo reprodutivo sobre o valor nutritivo da forragem em oferta no pré-pastejo, particularmente nos tratamentos de maior florescimento (resíduo de $50 \mathrm{~cm}$ e /ou 100\% IL).

Tabela 45. Proporção de hastes florescidas (\%) nos estratos basal e superior da massa de forragem em pré-pastejo de capim-Mombaça submetido a combinações de intervalos entre pastejos (IL) e intensidades de pastejo (altura do resíduo) durante o período de janeiro de 2001 a fevereiro de 2002

\begin{tabular}{cccc}
\hline & Basal & Estrato & Superior \\
Época do ano & $0,0^{\mathrm{aA}}(2,04)$ & $0,0^{\mathrm{aB}}(2,04)$ & $0,0^{\mathrm{B}}(1,44)$ \\
\hline Verão & $2,2^{\mathrm{bA}}(2,04)$ & $16,7^{\mathrm{aA}}(2,04)$ & $9,5^{\mathrm{A}}(1,44)$ \\
Outono/Inverno & $0,0^{\mathrm{aA}}(2,04)$ & $0,0^{\mathrm{aB}}(2,04)$ & $0,0^{\mathrm{B}}(1,44)$ \\
Primavera & $0,7^{\mathrm{b}}(1,18)$ & $5,6^{\mathrm{a}}(1,18)$ & \\
Média &
\end{tabular}

Médias na mesma coluna seguidas de mesma letra maiúscula não diferem entre si $(P>0,10)$ Médias na mesma linha seguidas de mesma letra minúscula não diferem entre si $(P>0,10)$ Valores entre parênteses indicam erro padrão da média

Tabela 46. Proporção de hastes florescidas (\%) na massa de forragem em pré-pastejo de capim-Mombaça com pastejos realizados a 30 e $50 \mathrm{~cm}$ de resíduo durante o período de janeiro de 2001 a fevereiro de 2002

\begin{tabular}{cccc}
\hline Época do ano & 30 & 50 & Mesíduo $(\mathrm{cm})$ \\
\hline Verão & $0,0^{\mathrm{aA}}(2,04)$ & $0,0^{\mathrm{aB}}(2,04)$ & $0,0^{\mathrm{B}}(1,44)$ \\
Outono/Inverno & $4,7^{\mathrm{bA}}(2,04)$ & $14,2^{\mathrm{aA}}(2,04)$ & $9,5^{\mathrm{A}}(1,44)$ \\
Primavera & $0,0^{\mathrm{aA}}(2,04)$ & $0,0^{\mathrm{aB}}(2,04)$ & $0,0^{\mathrm{B}}(1,44)$ \\
Média & $1,6^{\mathrm{b}}(1,18)$ & $4,7^{\mathrm{a}}(1,18)$ &
\end{tabular}

Médias na mesma coluna seguidas de mesma letra maiúscula não diferem entre si $(\mathrm{P}>0,10)$

Médias na mesma linha seguidas de mesma letra minúscula não diferem entre si $(P>0,10)$

Valores entre parênteses indicam erro padrão da média 
Durante o período de desenvolvimento reprodutivo intenso (outono/inverno), houve efeito de resíduo $(\mathrm{P}=0,0238)$, estrato $(\mathrm{P}=0,0001)$ e das interações interceptação luminosa $\mathrm{x}$ estrato $(\mathrm{P}=0,0326)$ e resíduo $\mathrm{x}$ interceptação luminosa $(\mathrm{P}=0,0292)$ sobre a proporção de hastes florescidas em pré-pastejo (Tabela 47). Os tratamentos de resíduo 50 $\mathrm{cm}$ favoreceram o processo de florescimento e resultaram na maior proporção de hastes florescidas relativamente àqueles de $30 \mathrm{~cm}$. A interação resíduo x interceptação luminosa foi função da maior proporção de hastes florescidas no tratamento de $95 \%$ IL em relação ao de 100\% IL para o resíduo de $50 \mathrm{~cm}$, demonstrando, mais uma vez, a maior importância relativa da intensidade comparativamente à freqüência de pastejo no controle do desenvolvimento de hastes e do processo reprodutivo. Esses resultados corroboram aqueles obtidos por Uebele (2002) quando da avaliação dos padrões demográficos de perfilhamento de capim-Mombaça em experimento concomitante na mesma área experimental, e auxiliam no entendimento da menor produção total de forragem para o tratamento 50/95 comparativamente aos demais tratamentos $(30 / 95,30 / 100$ e 50/100 em ordem decrescente de produção).

Tabela 47. Proporção de hastes florescidas (\%) na massa de forragem em pré-pastejo de capim-Mombaça submetido a combinações de intervalos entre pastejos (IL) e intensidades de pastejo (altura do resíduo) durante o período de abril de 2001 a setembro de 2001

\begin{tabular}{cccc}
\hline & \multicolumn{2}{c}{ Interceptação Luminosa (\%) } \\
Resíduo $(\mathrm{cm})$ & 95 & 100 & Média \\
\hline 30 & $5,7^{\mathrm{aB}}(2,56)$ & $9,6^{\mathrm{aA}}(2,56)$ & $7,6^{\mathrm{B}}(1,81)$ \\
50 & $17,7^{\mathrm{aA}}(2,56)$ & $9,8^{\mathrm{bA}}(2,56)$ & $13,7^{\mathrm{A}}(1,81)$ \\
Média & $11,7^{\mathrm{a}}(1,81)$ & $9,7^{\mathrm{a}}(1,81)$ & \\
\hline
\end{tabular}

Médias na mesma coluna seguidas de mesma letra maiúscula não diferem entre si $(P>0,10)$ Médias na mesma linha seguidas de mesma letra minúscula não diferem entre si $(\mathrm{P}>0,10)$ Valores entre parênteses indicam erro padrão da média

Nessa época do ano, também, as maiores proporções de hastes florescidas ocorreram no estrato superior e decresceram ao longo do perfil do dossel em direção à base do pasto. A interação interceptação luminosa x estrato ocorreu pelo maior aumento 
proporcional de hastes reprodutivas no estrato superior dos tratamentos de $100 \%$ IL relativamente àqueles de $95 \%$ IL (Tabela 48 ).

Tabela 48. Proporção de hastes florescidas (\%) nos estratos basal, mediano e superior da massa de forragem em pré-pastejo de capim-Mombaça com pastejos realizados a 95 e $100 \%$ de interceptação luminosa do dossel forrageiro durante o período de abril de 2001 a setembro de 2001

\begin{tabular}{cccc}
\hline & \multicolumn{2}{c}{ Interceptação Luminosa $(\%)$} & Média \\
Estrato & 95 & 100 & $2,2^{\mathrm{C}}(2,22)$ \\
Basal & $4,4^{\mathrm{aB}}(3,14)$ & $0,0^{\mathrm{aB}}(3,14)$ & $8,7^{\mathrm{B}}(2,22)$ \\
Mediano & $13,3^{\mathrm{aA}}(3,14)$ & $4,0^{\mathrm{bB}}(3,14)$ & $21,2^{\mathrm{A}}(2,22)$ \\
Superior & $17,4^{\mathrm{bA}}(3,14)$ & $25,0^{\mathrm{aA}}(3,14)$ & \\
Média & $11,7^{\mathrm{a}}(1,81)$ & $9,7^{\mathrm{a}}(1,81)$ & \\
\hline
\end{tabular}

Médias na mesma coluna seguidas de mesma letra maiúscula não diferem entre si $(\mathrm{P}>0,10)$

Médias na mesma linha seguidas de mesma letra minúscula não diferem entre si $(\mathrm{P}>0,10)$

Valores entre parênteses indicam erro padrão da média

\subsubsection{Composição Química}

As avaliações químicas foram realizadas nas amostras referentes aos períodos de rebrotação e à condição de pré-pastejo.

\subsubsection{Matéria Mineral}

Não houve variação nos teores de matéria mineral em função de resíduo e interceptação luminosa durante a rebrotação. Houve efeito de altura $(\mathrm{P}=0,0372)$, época do ano $(\mathrm{P}=0,0001)$ e da interação altura $\mathrm{x}$ época do ano $(\mathrm{P}=0,0071)$. Os valores de matéria mineral apresentaram uma pequena variação ao longo das estações do ano, sendo o outono/inverno a época que apresentou a maior porcentagem de matéria mineral e a primavera a que apresentou a menor porcentagem. Normalmente não houve variação nos teores de matéria mineral com as alturas de rebrotação, exceção feita à altura +40 na primavera, que resultou na interação altura x época do ano. Não 
ocorreu variação nas porcentagens de matéria mineral ao longo do ano para a fase de rebrotação mais avançada (altura +40 ), provavelmente devido ao menor risco de ocorrência de contaminação da forragem por terra relativamente à fase inicial de rebrotação (Tabela 49).

Os valores médios do experimento foram superiores àqueles relatados por Balsalobre (2002) em trabalho realizado com capim-Tanzânia (Panicum maximum cv. Tanzânia) (7,9 a 10,5\%). Esse autor relatou que os valores obtidos seguiram tendência de altos teores de matéria mineral (MM), comuns em pastagens tropicais adubadas. A diferença entre os valores contidos na Tabela 49 e aqueles reportados por Balsalobre (2002) pode estar associada ao fato de as amostras não terem sido lavadas antes do processamento neste experimento, podendo ter sido contaminadas por terra que conseqüentemente, elevou a porcentagem de matéria mineral (MM).

Tabela 49. Porcentagem de matéria mineral na massa de forragem durante a rebrotação de capim-Mombaça submetido a combinações de intervalos entre pastejos (IL) e intensidades de pastejo (altura do resíduo) durante o período de janeiro de 2001 a fevereiro de 2002

\begin{tabular}{|c|c|c|c|}
\hline \multicolumn{4}{|c|}{ Fase de Rebrotação } \\
\hline Época do ano & +20 & +40 & Média \\
\hline Verão & $11,0^{\mathrm{aB}}(0,15)$ & $11,3^{\mathrm{aA}}(0,15)$ & $11,2^{\mathrm{B}}(0,11)$ \\
\hline Outono/Inverno & $11,8^{\mathrm{aA}}(0,27)$ & $11,7^{\mathrm{aA}}(0,33)$ & $11,8^{\mathrm{A}}(0,21)$ \\
\hline Primavera & $10,1^{\mathrm{bC}}(0,11)$ & $11,2^{\mathrm{aA}}(0,11)$ & $10,6^{\mathrm{C}}(0,08)$ \\
\hline Média & $11,0^{\mathrm{b}}(0,13)$ & $11,4^{\mathrm{a}}(0,15)$ & \\
\hline
\end{tabular}

Médias na mesma coluna seguidas de mesma letra maiúscula não diferem entre si $(P>0,10)$

Médias na mesma linha seguidas de mesma letra minúscula não diferem entre si $(\mathrm{P}>0,10)$

Valores entre parênteses indicam erro padrão da média

$\mathrm{Na}$ condição de pré-pastejo, houve efeito de resíduo $(\mathrm{P}=0,0043)$, interceptação luminosa ( $\mathrm{P}=0,0396)$, época do ano $(\mathrm{P}=0,0687)$ e da interação interceptação luminosa $\mathrm{x}$ estrato x época do ano $(\mathrm{P}=0,0678)$. Foi observada uma maior proporção de matéria mineral para os tratamentos de resíduo $30 \mathrm{~cm}$ em relação aos de $50 \mathrm{~cm}(12,1$ x 11,6\% 
cm $\mathrm{EPM}=0,12$, respectivamente), provavelmente conseqüência de maior contaminação por terra em função da menor altura de resíduo.

Com relação à interceptação de luz, os tratamentos com pastejos iniciados com 100\% IL apresentaram as maiores proporções de matéria mineral comparativamente àqueles de $95 \%$ IL durante o verão (Tabela 50). Normalmente era necessário maior pressão de pastejo nesses pastos, especialmente nos de resíduo $30 \mathrm{~cm}$, o que deve ter propiciado condições para maior contaminação da amostra $\mathrm{cm}$ terra, elevando as porcentagens de matéria mineral. Com relação às épocas do ano, os maiores valores foram observados durante o outono/inverno.

Tabela 50. Porcentagem de matéria mineral nos estratos basal e superior da massa de forragem em pré-pastejo de capim-Mombaça com pastejos realizados a 95 e $100 \%$ de interceptação luminosa do dossel forrageiro durante o período de janeiro de 2001 a fevereiro de 2002

\begin{tabular}{ccccc}
\hline \multicolumn{5}{c}{ Interceptação Luminosa $(\%)$} \\
Estrato & \multicolumn{9}{c}{95} & 100 & Média & Média Época \\
\hline Basal & $11,8^{\mathrm{aA}}(0,29)$ & $12,1^{\mathrm{aA}}(0,29)$ & $12,0(0,21)$ & \\
Superior & $11,4^{\mathrm{bA}}(0,29)$ & $12,2^{\mathrm{aA}}(0,29)$ & $11,8(0,21)$ & $11,9^{\mathrm{B}}(0,15)$ \\
Média & $11,6^{\mathrm{b}}(0,21)$ & $12,2^{\mathrm{a}}(0,21)$ & & \\
\multicolumn{7}{c}{ Outono/Inverno } \\
Basal & $11,8^{\mathrm{aA}}(0,29)$ & $12,4^{\mathrm{aA}}(0,29)$ & $12,1(0,21)$ & \\
Superior & $12,2^{\mathrm{aA}}(0,29)$ & $11,9^{\mathrm{aA}}(0,29)$ & $12,1(0,21)$ & $12,1^{\mathrm{A}}(0,15)$ \\
Média & $12,0^{\mathrm{a}}(0,21)$ & $12,1^{\mathrm{a}}(0,21)$ & & \\
\multicolumn{5}{c}{ Primavera } \\
Basal & $11,6^{\mathrm{aA}}(0,29)$ & $11,5^{\mathrm{aA}}(0,29)$ & $11,5(0,21)$ & \\
Superior & $11,2^{\mathrm{bA}}(0,29)$ & $12,1^{\mathrm{aA}}(0,29)$ & $11,6(0,21)$ & $11,6^{\mathrm{B}}(0,15)$ \\
Média & $11,4^{\mathrm{a}}(0,21)$ & $11,8^{\mathrm{a}}(0,21)$ & \\
\hline
\end{tabular}

Médias na mesma coluna seguidas de mesma letra maiúscula não diferem entre si $(\mathrm{P}>0,10)$ Médias na mesma linha seguidas de mesma letra minúscula não diferem entre si $(\mathrm{P}>0,10)$

Valores entre parênteses indicam erro padrão da média 
Durante o período de outono/inverno, época de desenvolvimento reprodutivo intenso, houve efeito de resíduo $(\mathrm{P}=0,0004)$, interceptação luminosa $(\mathrm{P}=0,0020)$ e estrato $(\mathrm{P}=0,0001)$, além das interações resíduo $\mathrm{x}$ interceptação luminosa $(\mathrm{P}=0,0452)$ e estrato $\mathrm{x}$ interceptação luminosa $(\mathrm{P}=0,0009)$. $\mathrm{O}$ resíduo de $30 \mathrm{~cm}$ apresentou média maior que o resíduo de $50 \mathrm{~cm}$. A interação resíduo $\mathrm{x}$ interceptação luminosa foi caracterizada pela não ocorrência de diferença nos teores de matéria mineral entre os resíduos quando associados com pastejos aos 100\% IL (Tabela 51). Novamente, parece haver a indicação de que pastejos mais intensos $(30 \mathrm{~cm})$ ou que requerem o uso de maior pressão de pastejo (100\% IL) para retornar os pastos à condição original de resíduo, possibilitaram a ocorrência de maior contaminação das amostras por terra resultando, como conseqüência, em porcentagens mais elevadas de matéria mineral.

Tabela 51. Porcentagem de matéria mineral na massa de forragem em pré-pastejo de capim-Mombaça submetido a combinações de intervalos entre pastejos (IL) e intensidades de pastejo (altura do resíduo) durante o período de abril de 2001 a setembro de 2001

\begin{tabular}{cccc}
\hline & \multicolumn{2}{c}{ Interceptação Luminosa $(\%)$} & \\
Resíduo $(\mathrm{cm})$ & 95 & 100 & Média \\
\hline 30 & $12,0^{\mathrm{aA}}(0,21)$ & $12,3^{\mathrm{aA}}(0,21)$ & $12,1^{\mathrm{A}}(0,16)$ \\
50 & $10,7^{\mathrm{bB}}(0,21)$ & $11,8^{\mathrm{aA}}(0,21)$ & $11,3^{\mathrm{B}}(0,16)$ \\
Média & $11,3^{\mathrm{b}}(0,15)$ & $12,1^{\mathrm{a}}(0,15)$ & \\
\hline
\end{tabular}

Médias na mesma coluna seguidas de mesma letra maiúscula não diferem entre si $(P>0,10)$

Médias na mesma linha seguidas de mesma letra minúscula não diferem entre si $(P>0,10)$

Valores entre parênteses indicam erro padrão da média

Os teores de matéria mineral dos estratos basal e mediano não foram diferentes entre si, mas foram superiores àqueles do estrato superior (Tabela 52). A interação interceptação luminosa $\mathrm{x}$ estrato ocorreu provavelmente devido a uma diminuição do valor da matéria mineral no estrato superior para ambos intervalos entre pastejos, sendo que o menor intervalo entre pastejos (95\% IL) apresentou uma queda mais acentuada. Esse fato pode estar relacionado com a tendência de menor proporção de hastes 
florescidas que os tratamentos de 95\% IL apresentaram em sua composição morfológica relativamente àqueles de $100 \%$ IL (Tabela 47). Sendo assim, e como os pastos manejados com o tratamento 30/95 controlaram mais eficientemente o florescimento das plantas, é provável que a maior presença das panículas no estrato superior dos tratamentos de $100 \%$ IL (Tabela 48) contribuíram para elevar o teor de matéria mineral (MM) no período do outono/inverno.

Tabela 52. Porcentagem de matéria mineral nos estratos basal, mediano e superior da massa de forragem em pré-pastejo de capim-Mombaça com pastejos realizados a 95 e $100 \%$ de interceptação luminosa do dossel forrageiro durante o período de abril de 2001 a setembro de 2001

\begin{tabular}{cccc}
\hline & \multicolumn{2}{c}{ Interceptação Luminosa $(\%)$} & Média \\
Estrato & 95 & 100 & $12,1^{\mathrm{A}}(0,19)$ \\
\hline Basal & $11,8^{\mathrm{aA}}(0,26)$ & $12,4^{\mathrm{aA}}(0,26)$ & $12,2^{\mathrm{A}}(0,19)$ \\
Mediano & $12,4^{\mathrm{aA}}(0,26)$ & $12,1^{\mathrm{aB}}(0,26)$ & $10,8^{\mathrm{B}}(0,19)$ \\
Superior & $9,8^{\mathrm{bB}}(0,26)$ & $11,7^{\mathrm{aB}}(0,26)$ & \\
Média & $11,3^{\mathrm{b}}(0,15)$ & $12,1^{\mathrm{a}}(0,15)$ & \\
\hline
\end{tabular}

Médias na mesma coluna seguidas de mesma letra maiúscula não diferem entre si $(P>0,10)$

Médias na mesma linha seguidas de mesma letra minúscula não diferem entre si $(P>0,10)$

Valores entre parênteses indicam erro padrão da média

\subsubsection{Proteína Bruta (PB)}

Houve efeito de resíduo $(\mathrm{P}=0,0052)$, altura do dossel $(\mathrm{P}=0,0441)$, época do ano $(\mathrm{P}=0,0001)$ e das interações altura do dossel $\mathrm{x}$ resíduo $\mathrm{x}$ época do ano $(\mathrm{P}=0,0005)$, resíduo $\mathrm{x}$ interceptação luminosa $(\mathrm{P}=0,0480)$ e interceptação luminosa $\mathrm{x}$ época do ano $(\mathrm{P}=0,0621)$ para o teor de proteína bruta $(\mathrm{PB})$ ao longo da rebrotação dos pastos.

Os teores de proteína bruta foram superiores para os tratamentos de resíduo 30 $\mathrm{cm}$ em relação àqueles de $50 \mathrm{~cm}$ no verão e na primavera. No período outono/inverno 
não foi observado efeito de resíduo $(\mathrm{P}=0,3581)$ (Tabela 53). Com relação à época do ano, os maiores teores de proteína bruta ocorreram nas épocas de primavera e verão relativamente ao outono/inverno, refletindo as variações no estádio de desenvolvimento dos pastos, fases vegetativa e reprodutiva, respectivamente.

A interação altura do dossel $\mathrm{x}$ resíduo $\mathrm{x}$ época do ano foi caracterizada pelas variações nos teores de proteína bruta observados durante a primavera. Essa foi a única época do ano em que $+20 \mathrm{~cm}$ teve teor de proteína bruta menor que $+40 \mathrm{~cm}$ para o resíduo de $30 \mathrm{~cm}$, particularmente devido ao início da rebrotação ocorrida nesse período, onde as avaliações de $+20 \mathrm{~cm}$ continham maior proporção de material senescido proveniente da fase reprodutiva do período de outono/inverno. Já a porção $+40 \mathrm{~cm}$ apresentava-se com maior proporção de material vivo, conseqüência da intensa rebrotação ocorrida no início da época de primavera (Tabela 22).

Tabela 53. Porcentagem de proteína bruta na massa de forragem durante a rebrotação de capim-Mombaça com pastejos realizados a 30 e $50 \mathrm{~cm}$ de resíduo durante o período de janeiro de 2001 a fevereiro de 2002

\begin{tabular}{ccccc}
\hline \multicolumn{5}{c}{ Fase de Rebrotação } \\
Resíduo $(\mathrm{cm})$ & +20 & +40 & Média & Média Época \\
\hline \multicolumn{5}{c}{ Verão } \\
30 & $15,9^{\mathrm{aA}}(0,51)$ & $14,9^{\mathrm{aA}}(0,51)$ & $15,4^{\mathrm{A}}(0,36)$ & \\
50 & $14,2^{\mathrm{aB}}(0,51)$ & $12,9^{\mathrm{bB}}(0,51)$ & $13,5^{\mathrm{B}}(0,36)$ & $14,5^{\mathrm{A}}(0,25)$ \\
Média & $15,0^{\mathrm{a}}(0,36)$ & $13,9^{\mathrm{b}}(0,36)$ & & \\
5 & Outono/Inverno \\
30 & $13,8^{\mathrm{aA}}(0,75)$ & $10,1^{\mathrm{bA}}(0,75)$ & $11,9^{\mathrm{A}}(0,53)$ & \\
50 & $10,8^{\mathrm{aB}}(0,75)$ & $11,3^{\mathrm{aA}}(1,19)$ & $11,1^{\mathrm{A}}(0,70)$ & $11,5^{\mathrm{B}}(0,44)$ \\
Média & $12,3^{\mathrm{a}}(0,53)$ & $10,7^{\mathrm{b}}(0,70)$ & & \\
30 & $14,3^{\mathrm{bA}}(0,50)$ & $16,3^{\mathrm{aA}}(0,50)$ & $15,3^{\mathrm{A}}(0,35)$ & \\
50 & $15,1^{\mathrm{aA}}(0,50)$ & $13,4^{\mathrm{bB}}(0,50)$ & $14,3^{\mathrm{B}}(0,35)$ & $14,8^{\mathrm{A}}(0,25)$ \\
Média & $14,7^{\mathrm{a}}(0,35)$ & $14,9^{\mathrm{a}}(0.35)$ \\
\hline
\end{tabular}

Médias na mesma coluna seguidas de mesma letra maiúscula não diferem entre si $(P>0,10)$ Médias na mesma linha seguidas de mesma letra minúscula não diferem entre si $(P>0,10)$ Valores entre parênteses indicam erro padrão da média 
De maneira geral, os primeiros $20 \mathrm{~cm}$ de rebrotação apresentaram teores de proteína bruta superiores àqueles dos $20 \mathrm{~cm}$ seguintes $(+40 \mathrm{~cm})$, seguramente conseqüência de tecidos mais jovens, com menor proporção de componentes de parede celular. Pastos desfolhados mais intensamente $(30 \mathrm{~cm})$ tenderam a apresentar valores mais elevados de proteína bruta que pastos desfolhados de forma mais leniente $(50 \mathrm{~cm})$

Com relação à interação interceptação luminosa x época do ano (Tabela 54), pode-se observar que houve um aumento de 1 unidade percentual no valor de proteína bruta no período de primavera em relação ao período de verão. Esse aumento reflete a presença de folhas novas existentes nessa época proporcionado pelo início da estação de crescimento.

Tabela 54. Porcentagem de proteína bruta na massa de forragem durante a rebrotação de capim-Mombaça com pastejos realizados com 95 e $100 \%$ de interceptação luminosa do dossel forrageiro durante o período de janeiro de 2001 a fevereiro de 2002

\begin{tabular}{cccc}
\hline & \multicolumn{2}{c}{ Interceptação Luminosa $(\%)$} & Média \\
\hline Época do ano & 95 & 100 & $14,5^{\mathrm{A}}(0,25)$ \\
\hline Verão & $14,1^{\mathrm{aA}}(0,36)$ & $14,8^{\mathrm{aA}}(0,36)$ & $11,5^{\mathrm{B}}(0,44)$ \\
Outono/Inverno & $12,0^{\mathrm{aC}}(0,53)$ & $10,9^{\mathrm{aB}}(0,70)$ & $14,8^{\mathrm{A}}(0,25)$ \\
Primavera & $15,1^{\mathrm{aB}}(0,35)$ & $14,4^{\mathrm{aA}}(0,35)$ & \\
Média & $13,7^{\mathrm{a}}(0,26)$ & $13,4^{\mathrm{a}}(0,31)$ & \\
\hline
\end{tabular}

Médias na mesma coluna seguidas de mesma letra maiúscula não diferem entre si $(P>0,10)$

Médias na mesma linha seguidas de mesma letra minúscula não diferem entre si $(P>0,10)$

Valores entre parênteses indicam erro padrão da média

A interação resíduo $\mathrm{x}$ interceptação luminosa foi conseqüência da menor porcentagem de proteína bruta no tratamento de $95 \%$ IL quando associado ao resíduo de $50 \mathrm{~cm}$, seguramente conseqüência da menor remoção de folhas pelo pastejo nesse tratamento relativamente ao 30/95. Aparentemente o efeito benéfico da maior freqüência de utilização (menor período de descanso) foi mais que compensado pelo maior resíduo deixado no pós-pastejo (folhas mais velhas) (Tabela 55). A associação dos teores de proteína bruta à composição morfológica durante a rebrotação indica que o manejo da 
estrutura do dossel forrageiro através de pastejos mais intensos $(30 \mathrm{~cm})$ e mais freqüentes (95\% IL) gera maiores proporções de folhas, menores proporções de hastes e, conseqüentemente, a possibilidade de oferta de uma forragem de melhor valor nutritivo.

Tabela 55. Porcentagem de proteína bruta na massa de forragem durante a rebrotação de capim-Mombaça submetido a combinações de intervalos entre pastejos (IL) e intensidades de pastejo (altura do resíduo) durante o período de janeiro de 2001 a fevereiro de 2002

\begin{tabular}{cccc}
\hline & \multicolumn{2}{c}{ Interceptação Luminosa $(\%)$} & \\
Resíduo $(\mathrm{cm})$ & 95 & 100 & Média \\
\hline 30 & $14,8^{\mathrm{aA}}(0,37)$ & $13,6^{\mathrm{bA}}(0,37)$ & $14,2^{\mathrm{A}}(0,26)$ \\
50 & $12,7^{\mathrm{aB}}(0,37)$ & $13,2^{\mathrm{aA}}(0,37)$ & $13,0^{\mathrm{B}}(0,31)$ \\
Média & $13,7^{\mathrm{a}}(0,26)$ & $13,4^{\mathrm{a}}(0,31)$ & \\
\hline
\end{tabular}

Médias na mesma coluna seguidas de mesma letra maiúscula não diferem entre si $(\mathrm{P}>0,10)$

Médias na mesma linha seguidas de mesma letra minúscula não diferem entre si $(P>0,10)$

Valores entre parênteses indicam erro padrão da média

Para a condição de pré-pastejo, houve efeito de resíduo $(\mathrm{P}=0,0005)$, interceptação luminosa $(\mathrm{P}=0,0001)$, estrato $(\mathrm{P}=0,0001)$ e época do ano $(\mathrm{P}=0,0291)$. Também foi detectada a interação interceptação luminosa x época do ano $(\mathrm{P}=0,0083)$. Os maiores teores de proteína bruta foram observados para os tratamentos de resíduo $50 \mathrm{~cm}$ relativamente aos de resíduo $30 \mathrm{~cm}(11,1 \times$ x 9,1\% com EPM=0,33, respectivamente). Esse fato é compreendido quando os teores de proteína bruta são relacionados aos resultados da composição morfológica da forragem em pré-pastejo, onde os tratamentos de pastejos mais intensos $(30 \mathrm{~cm})$ tiveram uma menor proporção de folhas no estrato basal comparativamente àqueles onde o pastejo foi mais leniente $(50 \mathrm{~cm})$ (Tabela 32$)$, concordando com Cecato et al. (1985), que afirmaram que alturas de corte ou pastejos mais baixos podem retirar material mais fibroso e com menor teor de PB. Essa tendência também foi confirmada por Rego et al. (2001) estudando pastos de capim-Tanzânia manejados em 4 alturas variando de 20 a $80 \mathrm{~cm}$. Já Machado et al. (1998) não encontraram respostas nesse sentido quando estudaram o efeito da altura de corte para o capim-Mombaça manejado a 20 e $40 \mathrm{~cm}$. 
Com relação à época do ano, constatou-se que os teores de proteína bruta do outono/inverno se igualaram àqueles da primavera e do verão. Porém, os teores observados no verão foram superiores aos da primavera (Tabela 56). Costa et al. (2000) também não encontraram grandes diferenças nos teores de proteína bruta durante o período de verão e inverno. O menor intervalo entre pastejos (95\% IL) propiciou maiores teores de proteína bruta $(\mathrm{PB})$ em relação ao maior intervalo entre pastejos (100\% IL), certamente pelo fato de a maior frequência de pastejo ter proporcionado a colheita de tecidos mais jovens, ao passo que a menor frequência favoreceu o declínio dos teores de proteína bruta da forragem, conseqüência do processo natural de maturação da planta. Essa tendência também foi relatada nos trabalhos de Coward-Lord (1972) e Vieira et al. (1980), onde os autores revelaram decréscimo dos teores de proteína bruta com o avanço da idade da planta. Gomes (2001), avaliando os teores de proteína bruta na parte aérea do capim-Mombaça, obteve $10,3 \%, 9,6 \%$ e $8,8 \%$ para as ofertas de forragem 4, 8 e 12\%, respectivamente, para o período do verão. Braga (2001) também encontrou decréscimo nos teores de proteína bruta quando aumentou o intervalo entre cortes tanto no período de verão como no de inverno.

Tabela 56. Porcentagem proteína bruta na massa de forragem em pré-pastejo de capimMombaça com pastejos realizados a 95 e $100 \%$ de interceptação luminosa do dossel forrageiro durante o período de janeiro de 2001 a fevereiro de 2002

\begin{tabular}{cccc}
\hline & \multicolumn{4}{c}{ Interceptação Luminosa $(\%)$} & Média \\
\hline Época do ano & 95 & 100 & $10,5^{\mathrm{A}}(0,35)$ \\
Verão & $11,3^{\mathrm{aA}}(0,50)$ & $9,7^{\mathrm{bA}}(0,50)$ & $9,9^{\mathrm{AB}}(0,35)$ \\
Outono/Inverno & $10,9^{\mathrm{aA}}(0,50)$ & $9,0^{\mathrm{bAB}}(0,50)$ & $9,8^{\mathrm{B}}(0,35)$ \\
Primavera & $11,4^{\mathrm{aA}}(0,50)$ & $8,2^{\mathrm{bB}}(0,50)$ & \\
Média & $11,2^{\mathrm{a}}(0,33)$ & $9,0^{\mathrm{b}}(0,33)$ & \\
\hline
\end{tabular}

Médias na mesma coluna seguidas de mesma letra maiúscula não diferem entre si $(\mathrm{P}>0,10)$ Médias na mesma linha seguidas de mesma letra minúscula não diferem entre si $(\mathrm{P}>0,10)$ Valores entre parênteses indicam erro padrão da média 
A interação interceptação luminosa x época do ano foi caracterizada pela redução do teor de proteína bruta do outono/inverno para a primavera nos tratamentos de $100 \%$ IL, provavelmente devido ao controle ineficiente do florescimento, que promoveu a ocorrência de uma maior proporção de hastes florescidas para esses tratamentos durante o período de outono/inverno. Gerdes et al. (2000), avaliando o capim-Tanzânia com corte aos 35 dias, encontraram teores de proteína bruta (10,8\%) no verão semelhantes aos deste experimento, porém para as outras estações do ano obtiveram valores bem mais altos como $13,7 \%$ na primavera, $19,8 \%$ no outono e $15,3 \%$ no inverno. Segundo Euclides (1995), os cultivares de P. maximum tendem a apresentar pequena variação de valor nutritivo quando comparados sob as mesmas condições experimentais. Em um estudo de cultivares de Panicum maximum Euclides (1993) encontrou, avaliando plantas maduras na estação das águas, valores de 9,5,9,1, e 7,4\% para Colonião, Tobiatã e Tanzânia, respectivamente.

Os estratos superiores apresentaram maior porcentagem de proteína bruta em relação aos estratos inferiores ( 12,0 x $8,1 \%$ com EPM=0,33, respectivamente), conseqüência de uma maior proporção de material vivo e menor proporção de material morto. A composição do material vivo dos estratos também revelou maior proporção de folhas e menor proporção de hastes para o estrato superior comparativamente ao estrato inferior. Maiores teores de proteína bruta (PB) nas lâminas foliares (cerca de duas vezes) em relação às hastes foram relatados por Gomes (2001) em trabalho conduzido com capim-Mombaça. Gerdes et al. (2000) também encontraram a mesma relação entre os teores de proteína bruta da folha e da haste para o capim-Tanzânia. Esses resultados confirmam a afirmação de Sarmento et al. (1997) quanto a importância de privilegiar práticas de manejo que elevem a proporção de folhas na forragem devido a diferença existente nos teores de proteína bruta de folhas e hastes.

No período de outono/inverno, houve efeito de resíduo $(\mathrm{P}=0,0007)$, estrato $(\mathrm{P}=0,0001)$, e das interações interceptação luminosa $\mathrm{x}$ estrato $(\mathrm{P}=0,0019)$ e resíduo $\mathrm{x}$ estrato $\mathrm{x}$ interceptação luminosa $(\mathrm{P}=0,0011)$. $\mathrm{O}$ estrato basal apresentou um teor mais baixo de proteína bruta do que os estratos mediano e superior, certamente conseqüência da maior proporção de hastes e material senescente encontrados nessa porção do dossel 
forrageiro. A interação resíduo $\mathrm{x}$ estrato $\mathrm{x}$ interceptação luminosa foi resultado de um menor valor de proteína bruta no estrato superior do dossel do tratamento 30/95 (Tabela $57)$.

Tabela 57. Porcentagem de proteína bruta na massa de forragem em pré-pastejo de capim-Mombaça submetido a combinações de intervalos entre pastejos (IL) e intensidades de pastejo (altura do resíduo) durante o período de abril de 2001 a setembro de 2001

\begin{tabular}{ccccc}
\hline \multicolumn{5}{c}{ Interceptação Luminosa (\%) } \\
Resíduo (cm) & 95 & 100 & Média & Média Estrato \\
\hline \multicolumn{5}{c}{ Estrato Basal } \\
30 & $8,6^{\mathrm{bA}}(1,00)$ & $6,0^{\mathrm{aB}}(1,00)$ & $7,3^{\mathrm{B}}(0,71)$ \\
50 & $9,5^{\mathrm{aA}}(1,00)$ & $9,0^{\mathrm{aA}}(1,00)$ & $9,2^{\mathrm{A}}(0,71)$ & $8,3^{\mathrm{B}}(0,50)$ \\
Média & $9,1^{\mathrm{a}}(0,71)$ & $7,5^{\mathrm{a}}(0,71)$ & \\
\multicolumn{5}{c}{ Estrato Mediano } \\
30 & $12,0^{\mathrm{aA}}(1,00)$ & $8,5^{\mathrm{bB}}(1,00)$ & $10,2^{\mathrm{B}}(0,71)$ \\
50 & $13,0^{\mathrm{aA}}(1,00)$ & $11,3^{\mathrm{aA}}(1,00)$ & $12,2^{\mathrm{A}}(0,71)$ & $11,2^{\mathrm{A}}(0,50)$ \\
Média & $12,5^{\mathrm{a}}(0,71)$ & $9,9^{\mathrm{b}}(0,71)$ & \\
30 & $7,5^{\mathrm{bB}}(1,00)$ & $14,2^{\mathrm{aA}}(1,00)$ & $10,9^{\mathrm{B}}(0,71)$ \\
50 & $14,2^{\mathrm{aA}}(1,00)$ & $12,7^{\mathrm{aA}}(1,00)$ & $13,4^{\mathrm{A}}(0,71)$ & $12,2^{\mathrm{A}}(0,50)$ \\
Média & $10,8^{\mathrm{b}}(0,71)$ & $13,5^{\mathrm{a}}(0,71)$ \\
\hline
\end{tabular}

Médias na mesma coluna seguidas de mesma letra maiúscula não diferem entre si $(\mathrm{P}>0,10)$

Médias na mesma linha seguidas de mesma letra minúscula não diferem entre si $(P>0,10)$

Valores entre parênteses indicam erro padrão da média

Os tratamentos com interceptação de luz de 95\% apresentaram maiores valores de proteína bruta no estrato basal e mediano, sendo que no estrato superior essa maior média ocorreu para os tratamentos de 100\% IL (Tabela 57). O fato de os tratamentos com maior intervalo entre pastejos terem apresentado uma altura média maior que a dos tratamentos de menor intervalo entre pastejos, fez com que o estrato superior dos tratamentos de $100 \%$ IL e $30 \mathrm{~cm}$ de resíduo apresentassem uma maior proporção de folhas somada a uma maior quantidade de panículas elevando, dessa maneira, o teor de 
proteína bruta nesse estrato. Para o tratamento de $95 \%$ IL e $30 \mathrm{~cm}$ de resíduo, contudo, em função da menor altura do dossel forrageiro, o estrato superior apresentou relativamente menos folhas, predominando panículas e hastes reprodutivas, o que explicaria os menores valores de proteína bruta encontrados nessa época do ano sob aquelas circunstâncias.

\subsubsection{Fibra Insolúvel em Detergente Neutro (FDN)}

Houve efeito de resíduo ( $\mathrm{P}=0,0071)$, altura do dossel $(\mathrm{P}=0,0103)$, época do ano $(\mathrm{P}=0,0001)$ e das interações resíduo $\mathrm{x}$ altura do dossel $(\mathrm{P}=0,0869)$, interceptação luminosa $\mathrm{x}$ altura do dossel $(\mathrm{P}=0,0001)$ e altura do dossel $\mathrm{x}$ época do ano $(\mathrm{P}=0,0201)$ durante a fase de rebrotação.

Os tratamentos de maior intensidade de pastejo (resíduo 30cm) apresentaram menores valores de FDN, gerados por uma diminuição desse valor nas avaliações de +40 cm. Para as avaliações de $+20 \mathrm{~cm}$ não houve diferença entre os valores de FDN associados aos diferentes resíduos (Tabela 58).

Tabela 58. Porcentagem de fibra insolúvel em detergente neutro na massa de forragem durante a rebrotação de capim-Mombaça com pastejos realizados a 30 e 50 cm de resíduo durante o período de janeiro de 2001 a fevereiro de 2002

\begin{tabular}{cccc}
\hline \multicolumn{4}{c}{ Fase de Rebrotação } \\
Resíduo $(\mathrm{cm})$ & +20 & +40 & Média \\
\hline 30 & $67,3^{\mathrm{aA}}(0,24)$ & $66,0^{\mathrm{bB}}(0,24)$ & $66,6^{\mathrm{B}}(0,17)$ \\
50 & $67,6^{\mathrm{aA}}(0,24)$ & $67,3^{\mathrm{aA}}(0,38)$ & $67,5^{\mathrm{A}}(0,22)$ \\
Média & $67,5^{\mathrm{a}}(0,17)$ & $66,7^{\mathrm{b}}(0,22)$ & \\
\hline
\end{tabular}

Médias na mesma coluna seguidas de mesma letra maiúscula não diferem entre si $(\mathrm{P}>0,10)$ Médias na mesma linha seguidas de mesma letra minúscula não diferem entre si $(P>0,10)$ Valores entre parênteses indicam erro padrão da média

Nas avaliações de $+20 \mathrm{~cm}$ na condição de $95 \%$ de IL durante a rebrotação, os valores de FDN foram menores que para os pastejos realizados a 100\% IL (Tabela 59). 
Já para as avaliações de $+40 \mathrm{~cm}$ de rebrotamento ocorreu o contrário, isto é, maiores valores de FDN para pastejos mais frequentes (95\% IL). Na média, os valores não diferiram entre as condições de 95 e $100 \%$ IL.

Tabela 59. Porcentagem de fibra insolúvel em detergente neutro na massa de forragem durante a rebrotação de capim-Mombaça com pastejos realizados a 95 e 100 \% de interceptação luminosa do dossel forrageiro durante o período de janeiro de 2001 a fevereiro de 2002

\begin{tabular}{cccc}
\hline & \multicolumn{2}{c}{ Fase de Rebrotação } \\
Interceptação Luminosa $(\%)$ & +20 & +40 & Média \\
\hline 95 & $66,8^{\mathrm{bB}}(0,24)$ & $67,5^{\mathrm{aA}}(0,24)$ & $67,2^{\mathrm{A}}(0,17)$ \\
100 & $68,1^{\mathrm{aA}}(0,24)$ & $65,9^{\mathrm{bB}}(0,38)$ & $67,0^{\mathrm{A}}(0,22)$ \\
Média & $67,5^{\mathrm{a}}(0,17)$ & $66,7^{\mathrm{b}}(0,22)$ &
\end{tabular}

Médias na mesma coluna seguidas de mesma letra maiúscula não diferem entre si $(\mathrm{P}>0,10)$

Médias na mesma linha seguidas de mesma letra minúscula não diferem entre si $(P>0,10)$

Valores entre parênteses indicam erro padrão da média

Tabela 60. Porcentagem de fibra insolúvel em detergente neutro na massa de forragem durante a rebrotação de capim-Mombaça submetido a combinações de intervalos entre pastejos (IL) e intensidades de pastejo (altura do resíduo) durante o período de janeiro de 2001 a fevereiro de 2002

\begin{tabular}{cccc}
\hline & \multicolumn{2}{c}{ Fase de Rebrotação } & \\
Época do ano & +20 & +40 & Média \\
\hline Verão & $68,6^{\mathrm{aA}}(0,27)$ & $67,6^{\mathrm{bA}}(0,27)$ & $68,1^{\mathrm{A}}(0,19)$ \\
Outono/Inverno & $65,4^{\mathrm{aB}}(0,51)$ & $66,1^{\mathrm{aB}}(0,67)$ & $65,8^{\mathrm{C}}(0,42)$ \\
Primavera & $68,4^{\mathrm{aA}}(0,27)$ & $66,3^{\mathrm{bB}}(0,27)$ & $67,4^{\mathrm{B}}(0,19)$ \\
Média & $67,5^{\mathrm{a}}(0,17)$ & $66,7^{\mathrm{b}}(0,22)$ & \\
\hline
\end{tabular}

Médias na mesma coluna seguidas de mesma letra maiúscula não diferem entre si $(P>0,10)$ Médias na mesma linha seguidas de mesma letra minúscula não diferem entre si $(P>0,10)$ Valores entre parênteses indicam erro padrão da média

Em relação à época do ano, os maiores valores de FDN foram encontrados durante o verão e os menores durante o outono/inverno. A interação altura do pasto $\mathrm{x}$ época do ano foi causada porque no outono/inverno o valor de FDN foi menor na 
avaliação de $+20 \mathrm{~cm}$ do que na avaliação de $+40 \mathrm{~cm}$, diferentemente do que ocorreu durante a primavera e o verão (Tabela 60).

Durante o pré-pastejo houve efeito de interceptação luminosa $(\mathrm{P}=0,0090)$, estrato $(\mathrm{P}=0,0001)$, época do ano $(\mathrm{P}=0,0056)$ e das interações resíduo $\mathrm{x}$ estrato $(\mathrm{P}=0,0026)$, resíduo x época do ano $(\mathrm{P}=0,0058)$ e interceptação luminosa x época do ano $(\mathrm{P}=0,0980)$.

Não houve diferença entre os valores de FDN para as intensidades de pastejo impostas como tratamento (resíduos de 30 e $50 \mathrm{~cm}$ ) (Tabela 61). A média foi de 68,4\%, sendo, no entanto, um valor bem menor do que os normalmente encontrados na literatura. Machado et al. (1998) também não encontraram efeito da altura de corte sobre os valores de FDN. Já Euclides (1999), estudando o consumo voluntário de três epécies de Panicum maximum sob pastejo, encontrou valores de 68,0, 69,2, 68,1\% para Colonião, Tobiatã e Tanzânia, respectivamente, quantificando o FDN de extrusa ruminal, valores esses semelhantes ao deste experimento.

$\mathrm{O}$ estrato basal apresentou maior valor de FDN que o estrato superior para as duas intensidades de pastejo estudadas. Essa variação no valor de fibra é conseqüência da variação de estrutura ao longo do perfil vertical do dossel forrageiro. (Tabela 61).

Tabela 61. Porcentagem de fibra insolúvel em detergente neutro nos estratos basal e superior da massa de forragem em pré-pastejo de capim-Mombaça com pastejos realizados a 30 e $50 \mathrm{~cm}$ de resíduo durante o período de janeiro de 2001 a fevereiro de 2002

\begin{tabular}{cccc}
\hline & \multicolumn{2}{c}{ Estrato } & Masal \\
Resíduo $(\mathrm{cm})$ & $71,1^{\mathrm{aA}}(0,27)$ & $66,1^{\mathrm{bA}}(0,27)$ & $68,6^{\mathrm{A}}(0,19)$ \\
\hline 30 & $69,8^{\mathrm{aB}}(0,27)$ & $66,6^{\mathrm{bA}}(0,27)$ & $68,2^{\mathrm{A}}(0,19)$ \\
50 & $70,5^{\mathrm{a}}(0,19)$ & $66,3^{\mathrm{b}}(0,19)$ & \\
Média & &
\end{tabular}

Médias na mesma coluna seguidas de mesma letra maiúscula não diferem entre si $(\mathrm{P}>0,10)$

Médias na mesma linha seguidas de mesma letra minúscula não diferem entre si $(\mathrm{P}>0,10)$

Valores entre parênteses indicam erro padrão da média

Em relação à época do ano, os valores de FDN do verão foram cerca de 1 unidade percentual superiores às demais estações do ano (Tabela 62). Machado et al. 
(1998) também encontraram valores de FDN inferiores no período de inverno comparativamente ao verão. Essa diferença pode ser gerada pela alta intensidade da atividade metabólica da planta durante o verão necessitando, assim, de um aumento de seus constituintes de parede celular para que não ocorra rompimento da célula devido a alta absorção de água. Já Braga (2001) encontrou valores semelhantes de FDN em relação às épocas do ano. A interação resíduo x época do ano ocorreu porque houve uma queda no valor de FDN na primavera para os tratamentos mais lenientes (resíduo de $50 \mathrm{~cm})$.

Tabela 62. Porcentagem de fibra insolúvel em detergente neutro na massa de forragem em pré-pastejo de capim-Mombaça com pastejos realizados a 30 e $50 \mathrm{~cm}$ de resíduo durante o período de janeiro de 2001 a fevereiro de 2002

\begin{tabular}{cccc}
\hline & 30 & 50 & Resíduo $(\mathrm{cm})$ \\
Época do ano & $69,1^{\mathrm{aA}}(0,32)$ & $69,0^{\mathrm{aA}}(0,32)$ & $69,0^{\mathrm{A}}(0,23)$ \\
\hline Verão & $67,9^{\mathrm{aB}}(0,50)$ & $68,5^{\mathrm{aA}}(0,50)$ & $68,2^{\mathrm{B}}(0,35)$ \\
Outono/Inverno & $68,9^{\mathrm{aAB}}(0,34)$ & $67,0^{\mathrm{bB}}(0,34)$ & $68,0^{\mathrm{B}}(0,24)$ \\
Primavera & $68,6^{\mathrm{a}}(0,19)$ & $68,2^{\mathrm{a}}(0,19)$ & \\
Média &
\end{tabular}

Médias na mesma coluna seguidas de mesma letra maiúscula não diferem entre si $(P>0,10)$

Médias na mesma linha seguidas de mesma letra minúscula não diferem entre si $(P>0,10)$

Valores entre parênteses indicam erro padrão da média

Os tratamentos de 95\% IL geraram um menor valor de FDN quando comparados àqueles de 100 \% IL (Tabela 63). A interação interceptação luminosa x época do ano foi provavelmente conseqüência da ausência de diferença entre os regimes de 95 e 100 \% IL durante o verão, diferentemente do que ocorreu durante o outono/inverno e primavera, quando 100 \% IL resultou em valores mais elevados de FDN que 95\% IL. Corrêa et al. (1998), estudando os capins Mombaça e Tanzânia com corte aos 35 dias, encontraram 75 e 74,5\% de FDN, respectivamente. Braga (2001) também não encontrou diferenças nos valores de FDN durante o período de verão ao aumentar o intervalo entre pastejos de 28 para 42 dias, porém a média de FDN encontrada por esse autor foi 75,3\%, ou seja, 6 
unidades percentuais superior à média verificada neste experimento. Herling et al. (2000) encontraram decrécimos nos teores de FDN ao longo dos pastejos independentemente do período de descanso (28 e 35 dias) e da oferta de forragem $(3,3$; 4,1e 4,9\%) estudados, e associaram esse decréscimo à diminuição do crescimento das plantas.

Tabela 63. Porcentagem de fibra insolúvel em detergente neutro na massa de forragem em pré-pastejo de capim-Mombaça com pastejos realizados a 95 e $100 \%$ de interceptação luminosa do dossel forrageiro durante o período de janeiro de 2001 a fevereiro de 2002

\begin{tabular}{cccc}
\hline & \multicolumn{2}{c}{ Interceptação Luminosa $(\%)$} & \\
Época do ano & 95 & 100 & Média \\
\hline Verão & $69,1^{\mathrm{aA}}(0,32)$ & $69,0^{\mathrm{aA}}(0,32)$ & $69,0^{\mathrm{A}}(0,23)$ \\
Outono/Inverno & $67,5^{\mathrm{bB}}(0,50)$ & $68,8^{\mathrm{aA}}(0,50)$ & $68,2^{\mathrm{B}}(0,35)$ \\
Primavera & $67,4^{\mathrm{bB}}(0,34)$ & $68,6^{\mathrm{aA}}(0,34)$ & $68,0^{\mathrm{B}}(0,24)$ \\
Média & $68,0^{\mathrm{b}}(0,19)$ & $68,8^{\mathrm{a}}(0,19)$ & \\
\hline
\end{tabular}

Médias na mesma coluna seguidas de mesma letra maiúscula não diferem entre si $(P>0,10)$ Médias na mesma linha seguidas de mesma letra minúscula não diferem entre si $(\mathrm{P}>0,10)$ Valores entre parênteses indicam erro padrão da média

No período de outono/inverno houve efeito apenas de estrato $(\mathrm{P}=0,0001)$ e das interações interceptação luminosa x estrato $(\mathrm{P}=0,0258)$ e resíduo x estrato $(\mathrm{P}=0,0249)$. $\mathrm{O}$ estrato basal apresentou o maior teor de FDN (Tabela 64) refletindo a menor relação folha:haste encontrada nessa porção do dossel. O estrato superior acabou apresentando valor superior ao do estrato mediano devido à característica estrutural própria da pastagem nessa época reprodutiva, que fez com que no estrato superior a proporção de hastes florescidas fosse maior do que no estrato mediano (Tabela 48). A interação interceptação luminosa x estrato foi caracterizada porque o tratamento com $95 \%$ de IL apresentou valor de FDN maior do que os de $100 \%$ IL para o estrato superior (Tabela 64). 
Tabela 64. Porcentagem de fibra insolúvel em detergente neutro nos estratos basal, mediano e superior da massa de forragem em pré-pastejo de capimMombaça com pastejos realizados a 95 e $100 \%$ de interceptação luminosa do dossel forrageiro durante o período de abril de 2001 a setembro de 2001

\begin{tabular}{cccc}
\hline & \multicolumn{2}{c}{ Interceptação Luminosa $(\%)$} \\
Estrato & 95 & 100 & Média \\
\hline Basal & $69,7^{\mathrm{aA}}(0,72)$ & $70,7^{\mathrm{aA}}(0,72)$ & $70,2^{\mathrm{A}}(0,51)$ \\
Mediano & $65,3^{\mathrm{aB}}(0,72)$ & $66,8^{\mathrm{aB}}(0,72)$ & $66,1^{\mathrm{C}}(0,51)$ \\
Superior & $68,7^{\mathrm{bA}}(0,72)$ & $66,4^{\mathrm{aB}}(0,72)$ & $67,6^{\mathrm{B}}(0,51)$ \\
Média & $67,9^{\mathrm{a}}(0,41)$ & $68,0^{\mathrm{a}}(0,41)$ &
\end{tabular}

Médias na mesma coluna seguidas de mesma letra maiúscula não diferem entre si $(P>0,10)$

Médias na mesma linha seguidas de mesma letra minúscula não diferem entre si $(P>0,10)$

Valores entre parênteses indicam erro padrão da média

A interação resíduo x estrato foi caracterizada pela diminuição do valor de FDN para o resíduo $30 \mathrm{~cm}$ em relação ao resíduo $50 \mathrm{~cm}$ no estrato mediano (Tabela 65). Essa diminuição esteve mais associada provavelmente à idade da haste para esse estrato quando comparados os resíduos do que em termos de quantidade de haste, visto que em termos de proporção de hastes e hastes florescidas não houve efeito da interação estrato $\mathrm{x}$ resíduo.

Tabela 65. Porcentagem de fibra insolúvel em detergente neutro nos estratos basal, mediano e superior da massa de forragem em pré-pastejo de capimMombaça com pastejos realizados a 30 e $50 \mathrm{~cm}$ de resíduo durante o período de abril de 2001 a setembro de 2001

\begin{tabular}{cccc}
\hline & 30 & 50 & Resíduo $(\mathrm{cm})$ \\
Estrato & $70,7^{\mathrm{aA}}(0,72)$ & $69,8^{\mathrm{aA}}(0,72)$ & $70,2^{\mathrm{A}}(0,51)$ \\
\hline Basal & $65,0^{\mathrm{bC}}(0,72)$ & $67,1^{\mathrm{aB}}(0,72)$ & $66,1^{\mathrm{C}}(0,51)$ \\
Mediano & $68,5^{\mathrm{aB}}(0,72)$ & $66,6^{\mathrm{bB}}(0,72)$ & $67,6^{\mathrm{B}}(0,51)$ \\
Superior & $68,1^{\mathrm{a}}(0,42)$ & $67,8^{\mathrm{a}}(0,42)$ & \\
Média &
\end{tabular}

Médias na mesma coluna seguidas de mesma letra maiúscula não diferem entre si $(\mathrm{P}>0,10)$

Médias na mesma linha seguidas de mesma letra minúscula não diferem entre si $(\mathrm{P}>0,10)$

Valores entre parênteses indicam erro padrão da média 


\subsubsection{Fibra Insolúvel em Detergente Ácido (FDA)}

Durante as avaliações de rebrotação, houve efeito das interações resíduo x altura do dossel $(\mathrm{P}=0,0263)$, interceptação luminosa $\mathrm{x}$ altura do dossel $(\mathrm{P}=0,0004)$ e interceptação luminosa x época do ano $(\mathrm{P}=0,0091)$. Os valores de FDA não diferiram em relação aos resíduos e às alturas do dossel (fase de rebrotação), porém para o resíduo de $30 \mathrm{~cm}$ associado à avaliação de $+40 \mathrm{~cm}$ houve uma redução de cerca de uma unidade percentual comparativamente à avaliação de $+20 \mathrm{~cm}$ para o mesmo resíduo (Tabela 66). Isso ocorreu devido à menor proporção de hastes existente nessa avaliação em relação à avaliação de $+20 \mathrm{~cm}$ (Tabela 37). Essa variação também esteve refletida nos valores de FDN (Tabela 66).

Tabela 66. Porcentagem de fibra insolúvel em detergente ácido na massa de forragem durante a rebrotação de capim-Mombaça com pastejos realizados a 30 e 50 cm de resíduo durante o período de janeiro de 2001 a fevereiro de 2002

\begin{tabular}{cccc}
\hline \multirow{2}{*}{ Resíduo $(\mathrm{cm})$} & $+20^{2}$ & +40 & Mase de Rebrotação \\
\hline 30 & $37,2^{\mathrm{aA}}(0,22)$ & $36,2^{\mathrm{bB}}(0,22)$ & $36,7^{\mathrm{A}}(0,15)$ \\
50 & $37,0^{\mathrm{aA}}(0,22)$ & $37,2^{\mathrm{aA}}(0,33)$ & $37,1^{\mathrm{A}}(0,20)$ \\
Média & $37,1^{\mathrm{a}}(0,15)$ & $36,7^{\mathrm{a}}(0,20)$ & \\
\hline
\end{tabular}

Médias na mesma coluna seguidas de mesma letra maiúscula não diferem entre si $(P>0,10)$

Médias na mesma linha seguidas de mesma letra minúscula não diferem entre si $(P>0,10)$

Valores entre parênteses indicam erro padrão da média

$\mathrm{Na}$ interação interceptação luminosa x altura do dossel, os tratamentos de 95\% IL apresentaram menor valor de FDA na avaliação de $+20 \mathrm{~cm}$ enquanto que para os pastejos iniciados com 100\% IL o menor valor foi encontrado para a avaliação de +40 cm (Tabela 67). Em relação às estações do ano, foi encontrado maior valor de FDA na primavera do que no verão mas, para pastejos realizados com $95 \%$ IL, essa diferença não ocorreu (Tabela 68). 
Tabela 67. Porcentagem de fibra insolúvel em detergente ácido na massa de forragem durante a rebrotação de capim-Mombaça com pastejos realizados a 95 e 100 $\%$ de interceptação luminosa do dossel forrageiro durante o período de janeiro de 2001 a fevereiro de 2002

\begin{tabular}{cccc}
\hline & \multicolumn{2}{c}{ Fase de Rebrotação } & Média \\
Interceptação Luminosa(\%) & +20 & +40 & $37,0(0,15)$ \\
\hline 95 & $36,6^{\mathrm{bB}}(0,22)$ & $37,2^{\mathrm{aA}}(0,22)$ & $36,9(0,20)$ \\
100 & $37,6^{\mathrm{aA}}(0,22)$ & $36,2^{\mathrm{bB}}(0,33)$ & \\
Média & $37,1(0,15)$ & $36,7(0,20)$ & \\
\hline
\end{tabular}

Médias na mesma coluna seguidas de mesma letra maiúscula não diferem entre si $(\mathrm{P}>0,10)$

Médias na mesma linha seguidas de mesma letra minúscula não diferem entre si $(P>0,10)$

Valores entre parênteses indicam erro padrão da média

Tabela 68. Porcentagem de fibra insolúvel em detergente ácido na massa de forragem durante a rebrotação de capim-Mombaça com pastejos realizados a 95 e 100 $\%$ de interceptação luminosa do dossel forrageiro durante o período de janeiro de 2001 a fevereiro de 2002

\begin{tabular}{cccc}
\hline & \multicolumn{4}{c}{ Interceptação Luminosa $(\%)$} \\
Época do ano & 95 & 100 & Média \\
\hline Verão & $37,3^{\mathrm{aA}}(0,34)$ & $35,9^{\mathrm{bB}}(0,34)$ & $36,6^{\mathrm{B}}(0,24)$ \\
Outono/Inverno & $36,5^{\mathrm{aA}}(0,45)$ & $37,2^{\mathrm{aA}}(0,58)$ & $36,8^{\mathrm{BA}}(0,37)$ \\
Primavera & $36,9^{\mathrm{bA}}(0,26)$ & $37,6^{\mathrm{aA}}(0,26)$ & $37,3^{\mathrm{A}}(0,18)$ \\
Média & $37,0^{\mathrm{a}}(0,15)$ & $36,9^{\mathrm{a}}(0,20)$ & \\
\hline
\end{tabular}

Médias na mesma coluna seguidas de mesma letra maiúscula não diferem entre si $(\mathrm{P}>0,10)$

Médias na mesma linha seguidas de mesma letra minúscula não diferem entre si $(\mathrm{P}>0,10)$

Valores entre parênteses indicam erro padrão da média

$\mathrm{Na}$ condição de pré-pastejo, houve efeito de resíduo $(\mathrm{P}=0,0011)$, interceptação luminosa ( $\mathrm{P}=0,0001)$, estrato ( $\mathrm{P}=0,0001)$, época do ano $(\mathrm{P}=0,0242)$, e das interações resíduo $\mathrm{x}$ interceptação luminosa $(\mathrm{P}=0,0639)$, resíduo $\mathrm{x}$ estrato $(\mathrm{P}=0,0001)$ e resíduo $\mathrm{x}$ época do ano $(\mathrm{P}=0,0069)$. Tratamentos com resíduo $30 \mathrm{~cm}$ apresentaram valor de FDA maior do que tratamentos com resíduo $50 \mathrm{~cm}$, o mesmo ocorrendo para os tratamentos de 100\% IL em relação aos de 95\% IL (Tabela 69). A interação resíduo x interceptação 
luminosa foi causada pela ausência de diferença entre os valores de FDA para os resíduos de 30 e $50 \mathrm{~cm}$ dos tratamentos de $95 \%$ IL, diferentemente do que ocorreu para pastejos iniciados com $100 \%$ IL. Machado et al. (1998) encontraram valores de FDA da ordem de 43,5 \% no verão e de 40,6\% no inverno em um estudo com cultivares e acessos de Panicum maximum Jacq, dentre eles o capim-Mombaça. Herling et al. (2000), estudando capim Tanzânia, Tobiatã e Mombaça, encontraram decréscimos nas porcentagens de FDA no decorrer das avaliações mostrando, assim, que a planta tende a apresentar diminuição dos constituintes de parede celular à medida que diminui seu metabolismo devido a condições climáticas desfavoráveis. Braga (2001) também encontrou um aumento no valor de FDA quando se aumentou o intervalo entre pastejos de 28 para 42 dias em capim-Mombaça.

Tabela 69. Porcentagem de fibra insolúvel em detergente ácido na massa de forragem em pré-pastejo de capim-Mombaça submetido a combinações de intervalos entre pastejos (IL) e intensidades de pastejo (altura do resíduo) durante o período de janeiro de 2001 a fevereiro de 2002

\begin{tabular}{cccc}
\hline \multirow{2}{*}{ Resíduo $(\mathrm{cm})$} & \multicolumn{2}{c}{ Interceptação Luminosa $(\%)$} & Média \\
\hline 30 & $38,2^{\mathrm{bA}}(0,19)$ & $400,2^{\mathrm{aA}}(0,19)$ & $39,2^{\mathrm{A}}(0,14)$ \\
50 & $37,9^{\mathrm{bA}}(0,19)$ & $39,1^{\mathrm{aB}}(0,19)$ & $38,5^{\mathrm{B}}(0,14)$ \\
Média & $38,1^{\mathrm{b}}(0,14)$ & $39,7^{\mathrm{a}}(0,14)$ & \\
\hline
\end{tabular}

Médias na mesma coluna seguidas de mesma letra maiúscula não diferem entre si $(\mathrm{P}>0,10)$

Médias na mesma linha seguidas de mesma letra minúscula não diferem entre si $(P>0,10)$

Valores entre parênteses indicam erro padrão da média

Na Tabela 70 pode-se observar que existiu uma variação de 4,5 pontos percentuais no valor de FDA para os diferentes estratos. Para o estrato basal houve diferença entre os resíduos de 30 e $50 \mathrm{~cm}$, o mesmo não ocorrendo para o estrato superior. Esses valores mostram mais uma vez a importância de realizar a colheita da forragem de maneira adequada para que se tenha controle sobre a variação na estrutura 
do dossel ao longo do pastejos evitando, assim, a queda no valor nutritivo da forragem mencionada por Corsi (1998).

Tabela 70. Porcentagem de fibra insolúvel em detergente ácido nos estratos basal e superior da massa de forragem em pré-pastejo de capim-Mombaça com pastejos realizados a 30 e $50 \mathrm{~cm}$ de resíduo durante o período de janeiro de 2001 a fevereiro de 2002

\begin{tabular}{cccc}
\hline \multirow{2}{*}{ Resíduo $(\mathrm{cm})$} & Basal & Superior & Média \\
\hline 30 & $41,9^{\mathrm{aA}}(0,19)$ & $36,5^{\mathrm{bA}}(0,19)$ & $39,2^{\mathrm{A}}(0,14)$ \\
50 & $40,3^{\mathrm{aB}}(0,19)$ & $36,7^{\mathrm{bA}}(0,19)$ & $38,5^{\mathrm{B}}(0,14)$ \\
Média & $41,1^{\mathrm{a}}(0,14)$ & $36,6^{\mathrm{b}}(0,14)$ & \\
\hline
\end{tabular}

Médias na mesma coluna seguidas de mesma letra maiúscula não diferem entre si $(P>0,10)$

Médias na mesma linha seguidas de mesma letra minúscula não diferem entre si $(P>0,10)$

Valores entre parênteses indicam erro padrão da média

Tabela 71. Porcentagem de fibra insolúvel em detergente ácido na massa de forragem em pré-pastejo de capim-Mombaça com pastejos realizados a 30 e $50 \mathrm{~cm}$ de resíduo durante o período de janeiro de 2001 a fevereiro de 2002

\begin{tabular}{cccc}
\hline & \multicolumn{2}{c}{ Resíduo $(\mathrm{cm})$} & 50 \\
Época do ano & 30 & $38,7^{\mathrm{bA}}(0,35)$ & $39,1^{\mathrm{A}}(0,25)$ \\
\hline Verão & $39,5^{\mathrm{aA}}(0,35)$ & $39,5^{\mathrm{aA}}(0,45)$ & $39,1^{\mathrm{A}}(0,32)$ \\
Outono/Inverno & $38,8^{\mathrm{aA}}(0,45)$ & $37,3^{\mathrm{bB}}(0,33)$ & $38,3^{\mathrm{B}}(0,23)$ \\
Primavera & $39,4^{\mathrm{aA}}(0,33)$ & $38,5^{\mathrm{b}}(0,14)$ & \\
Média & $39,2^{\mathrm{a}}(0,14)$ &
\end{tabular}

Médias na mesma coluna seguidas de mesma letra maiúscula não diferem entre si $(\mathrm{P}>0,10)$

Médias na mesma linha seguidas de mesma letra minúscula não diferem entre si $(\mathrm{P}>0,10)$

Valores entre parênteses indicam erro padrão da média

Ao longo das estações do ano a porcentagem de FDA foi menor durante a primavera, sendo que, quando associou-se a intensidade de pastejo com as estações do ano, os tratamentos de resíduo $30 \mathrm{~cm}$ apresentaram valores de FDA superiores àqueles de resíduo $50 \mathrm{~cm}$ durante a primavera e verão (Tabela 71). Durante o outono/inverno 
essa diferença desapareceu. A variação do teor de FDA ao longo do ano foi muito pequena, mostrando que um manejo adequado pode evitar que o valor nutritivo da forragem sofra alterações bruscas devido à falta de controle da estrutura do dossel (Tabela 71).

No período de outono/inverno, houve efeito de interceptação luminosa $(\mathrm{P}=0,0022)$, estrato $(\mathrm{P}=0,0001)$ e da interação resíduo $\mathrm{x}$ estrato $(\mathrm{P}=0,0053)$. Os pastejos iniciados com 100\% IL apresentaram valores de FDA 2 unidades percentuais superiores àqueles iniciados com $95 \%$ de IL ( $40,0 \times 38,1 \%$ com $\mathrm{EPM}=0,39$, respectivamente). Não houve efeito de resíduo sobre os valores de FDA. Entre os estratos pode-se dizer que o estrato basal apresentou maior valor de FDA, devido a própria estrutura da planta, sendo a base a porção onde se concentrou a maior proporção de hastes. $\mathrm{O}$ estrato mediano apresentou menor valor de FDA, conseqüência da maior presença de hastes florescidas no estrato superior, típica dessa fase reprodutiva. A interação resíduo $\mathrm{x}$ estrato foi causada pela ausência de diferença entre os valores de FDA para o estrato mediano e superior nos tratamentos com resíduo $50 \mathrm{~cm}$ (Tabela 72).

Tabela 72. Porcentagem de fibra insolúvel em detergente ácido nos estratos basal, mediano e superior da massa de forragem em pré-pastejo de capimMombaça com pastejos realizados a 30 e $50 \mathrm{~cm}$ de resíduo durante o período de abril de 2001 a setembro de 2001

\begin{tabular}{cccc}
\hline \multicolumn{4}{c}{ Resíduo $(\mathrm{cm})$} \\
Estrato & 30 & 50 & Média \\
\hline Basal & $41,5^{\mathrm{aA}}(0,68)$ & $41,1^{\mathrm{aA}}(0,68)$ & $41,3^{\mathrm{A}}(0,48)$ \\
Mediano & $36.1^{\mathrm{bB}}(0,68)$ & $37,9^{\mathrm{aB}}(0,68)$ & $37,0^{\mathrm{C}}(0,48)$ \\
Superior & $40,2^{\mathrm{aA}}(0,68)$ & $37,2^{\mathrm{bB}}(0,68)$ & $38,7^{\mathrm{B}}(0,48)$ \\
Média & $39,3^{\mathrm{a}}(0,39)$ & $38,7^{\mathrm{a}}(0,39)$ &
\end{tabular}

Médias na mesma coluna seguidas de mesma letra maiúscula não diferem entre si $(\mathrm{P}>0,10)$

Médias na mesma linha seguidas de mesma letra minúscula não diferem entre si $(P>0,10)$

Valores entre parênteses indicam erro padrão da média 


\subsubsection{Digestibilidade in vitro da Matéria Orgânica (DIVMO)}

Durante as avaliações de rebrotação, houve efeito de resíduo $(\mathrm{P}=0,0074)$, interceptação luminosa $(\mathrm{P}=0,0560)$, altura do dossel $(\mathrm{P}=0,0057)$, época do ano $(\mathrm{P}=0,0001)$, e das intereções resíduo $\mathrm{x}$ interceptação luminosa $(\mathrm{P}=0,0199)$, interceptação luminosa $\mathrm{x}$ altura do dossel $(\mathrm{P}=0,0119)$, resíduo $\mathrm{x}$ época do ano $(\mathrm{P}=0,0289)$, interceptação luminosa $\mathrm{x}$ época do ano $(\mathrm{P}=0,0760)$ e altura do dossel x época do ano $(\mathrm{P}=0,0066)$.

Pode-se notar que o tratamento 30/95 apresentou o maior valor de DIVMO. Em média, o resíduo $30 \mathrm{~cm}$ e a interceptação luminosa de 95\% IL permitiram valores mais altos de DIVMO durante a fase de rebrotação (Tabela 73). Esse resultado reflete a maior proporção de folhas existentes durante a rebrotação do tratamento 30/95 em relação aos ao tratamento 30/100 (Tabela 29). Adicionalmente, o tratamento 30/95 apresentou também menor proporção de hastes para todas as épocas do ano em relação aos outros tratamentos (Tabela 36), indicando que o controle do valor nutritivo da forragem e da estrutura do dossel é função da combinação adequada entre intensidade e freqüência de desfolhação. Tanto o resíduo de $30 \mathrm{~cm}$ associado à condição de 100\% IL como 95\% IL associada ao resíduo de $50 \mathrm{~cm}$ resultaram em redução dos valores de DIVMO.

Tabela 73. Digestibilidade in vitro da matéria orgânica da massa de forragem durante a rebrotação de capim-Mombaça submetido a combinações de intervalos entre pastejos (IL) e intensidades de pastejo (altura do resíduo) durante o período de janeiro de 2001 a fevereiro de 2002

\begin{tabular}{cccc}
\hline & \multicolumn{2}{c}{ Interceptação Luminosa $(\%)$} & Média \\
\hline Resíduo $(\mathrm{cm})$ & 95 & 100 & $61,8^{\mathrm{A}}(0,43)$ \\
\hline 30 & $63,3^{\mathrm{aA}}(0,60)$ & $60,3^{\mathrm{bA}}(0,60)$ & $59,9^{\mathrm{B}}(0,48)$ \\
Média & $59,7^{\mathrm{aB}}(0,60)$ & $60,1^{\mathrm{aA}}(0,74)$ & \\
& $61,5^{\mathrm{a}}(0,43)$ & $60,2^{\mathrm{b}}(0,48)$ & \\
\hline
\end{tabular}

Médias na mesma coluna seguidas de mesma letra maiúscula não diferem entre si $(\mathrm{P}>0,10)$ Médias na mesma linha seguidas de mesma letra minúscula não diferem entre si $(\mathrm{P}>0,10)$ Valores entre parênteses indicam erro padrão da média 
Já em relação a altura do dossel, as avaliações de $+20 \mathrm{~cm}$ apresentaram valores de DIVMO menores do que para as avaliações de $+40 \mathrm{~cm}$ (Tabela 74). A justificativa para que isso tenha ocorrido é que no início da rebrotação a proporção de folhas ainda é pequena, existindo ainda uma maior proporção de material senescente quando comparada com a avaliação de $+40 \mathrm{~cm}$ (Tabela 29). A interação interceptação luminosa $\mathrm{x}$ altura do dossel foi gerada porque para os tratamentos de $95 \%$ IL não foi detectada diferença de DIVMO para as diferentes fases da rebrotação.

Tabela 74. Digestibilidade in vitro da matéria orgânica da massa de forragem durante a rebrotação de capim-Mombaça com pastejos realizados a 95 e $100 \%$ de interceptação luminosa do dossel forrageiro durante o período de janeiro de 2001 a fevereiro de 2002

\begin{tabular}{cccc}
\hline \multicolumn{4}{c}{ Fase de Rebrotação } \\
Interceptação Luminosa (\%) & +20 & +40 & Média \\
\hline 95 & $61,4^{\mathrm{aA}}(0,60)$ & $61,6^{\mathrm{aA}}(0,60)$ & $61,5^{\mathrm{A}}(0,43)$ \\
100 & $58,3^{\mathrm{bB}}(0,60)$ & $62,1^{\mathrm{aA}}(0,74)$ & $60,2^{\mathrm{B}}(0,48)$ \\
Média & $59,9^{\mathrm{b}}(0,43)$ & $61,8^{\mathrm{a}}(0,48)$ & \\
\hline
\end{tabular}

Médias na mesma coluna seguidas de mesma letra maiúscula não diferem entre si $(P>0,10)$

Médias na mesma linha seguidas de mesma letra minúscula não diferem entre si $(P>0,10)$

Valores entre parênteses indicam erro padrão da média

Os valores de DIVMO diferiram de acordo com a época do ano, sendo a maior média registrada durante o verão $(64,3 \%)$ e a menor durante o outono/inverno $(55,5 \%)$ (Tabela 75). A interação resíduo x época do ano ocorreu porque no verão os valores de DIVMO diferiram para os resíduos de 30 e $50 \mathrm{~cm}$, diferença que não existiu durante o outono/inverno e primavera (Tabela 75). Com relação à interação época do ano $\mathrm{x}$ interceptação luminosa, não houve diferença entre os tratamentos de 95 e $100 \%$ IL durante o verão e o outono/inverno, diferentemente do que ocorreu na primavera, época em que pastejos iniciados com $95 \%$ IL resultaram em forragem com valores mais altos de DIVMO (Tabela 76), conseqüência de uma melhor estrutura do dossel, especialmente do resíduo (Tabela 20, 28, 36 e 45). 
Tabela 75. Digestibilidade in vitro da matéria orgânica da massa de forragem durante a rebrotação de capim-Mombaça com pastejos realizados a 30 e $50 \mathrm{~cm}$ de resíduo durante o período de janeiro de 2001 a fevereiro de 2002

\begin{tabular}{cccc}
\hline & \multicolumn{2}{c}{ Resíduo $(\mathrm{cm})$} & 50 \\
Época do ano & $66,4^{\mathrm{aA}}(0,74)$ & $62,3^{\mathrm{bA}}(0,74)$ & $64,3^{\mathrm{A}}(0,52)$ \\
\hline Verão & $56,3^{\mathrm{aC}}(0,74)$ & $54,8^{\mathrm{aB}}(0,98)$ & $55,5^{\mathrm{C}}(0,61)$ \\
Outono/Inverno & $62,7^{\mathrm{aB}}(0,74)$ & $62,6^{\mathrm{aA}}(0,74)$ & $62,7^{\mathrm{B}}(0,52)$ \\
Primavera & $61,8^{\mathrm{a}}(0,43)$ & $59,9^{\mathrm{b}}(0,48)$ & \\
Média &
\end{tabular}

Médias na mesma coluna seguidas de mesma letra maiúscula não diferem entre si $(P>0,10)$

Médias na mesma linha seguidas de mesma letra minúscula não diferem entre si $(\mathrm{P}>0,10)$

Valores entre parênteses indicam erro padrão da média

Tabela 76. Digestibilidade in vitro da matéria orgânica da massa de forragem durante a rebrotação de capim-Mombaça com pastejos realizados a 95 e $100 \%$ de interceptação luminosa do dossel forrageiro durante o período de janeiro de 2001 a fevereiro de 2002

\begin{tabular}{cccc}
\hline & \multicolumn{2}{c}{ Interceptação Luminosa $(\%)$} & Média \\
\hline Época do ano & 95 & 100 & $64,3^{\mathrm{A}}(0,52)$ \\
\hline Verão & $64,2^{\mathrm{aA}}(0,74)$ & $64,5^{\mathrm{aA}}(0,74)$ & $55,5^{\mathrm{C}}(0,61)$ \\
Outono/Inverno & $56,1^{\mathrm{aB}}(0,74)$ & $55,0^{\mathrm{aC}}(0,98)$ & $62,7^{\mathrm{B}}(0,52)$ \\
Primavera & $64,2^{\mathrm{aA}}(0,74)$ & $61,1^{\mathrm{bB}}(0,74)$ & \\
Média & $61,5^{\mathrm{a}}(0,48)$ & $60,2^{\mathrm{b}}(0,48)$ & \\
\hline
\end{tabular}

Médias na mesma coluna seguidas de mesma letra maiúscula não diferem entre si $(\mathrm{P}>0,10)$

Médias na mesma linha seguidas de mesma letra minúscula não diferem entre si $(\mathrm{P}>0,10)$

Valores entre parênteses indicam erro padrão da média

A interação altura do dossel $\mathrm{x}$ época do ano ocorreu porque a diferença que existiu entre os valores de DIVMO de acordo com as épocas do ano não ocorreu na avaliação de $+40 \mathrm{~cm}$ para os períodos de verão e primavera. Nesses mesmos períodos não houve diferença de DIVMO para as fases de rebrotação (Tabela 77). 
Tabela 77. Digestibilidade in vitro da matéria orgânica da massa de forragem durante a rebrotação de capim-Mombaça submetido a combinação de intervalos entre pastejos (IL) e intensidades de pastejo (altura do resíduo) durante o período de janeiro de 2001 a fevereiro de 2002

\begin{tabular}{cccc}
\hline & \multicolumn{2}{c}{ Fase de rebrotação } & \\
Época do ano & +20 & +40 & Média \\
\hline Verão & $64,7^{\mathrm{aA}}(0,74)$ & $64,0^{\mathrm{aA}}(0,74)$ & $64,3^{\mathrm{A}}(0,52)$ \\
Outono/Inverno & $53,2^{\mathrm{bC}}(0,74)$ & $57,9^{\mathrm{aB}}(0,98)$ & $55,5^{\mathrm{C}}(0,61)$ \\
Primavera & $61,7^{\mathrm{aB}}(0,74)$ & $63,7^{\mathrm{aA}}(0,74)$ & $62,7^{\mathrm{B}}(0,52)$ \\
Média & $59,9^{\mathrm{b}}(0,43)$ & $61,8^{\mathrm{a}}(0,48)$ & \\
\hline
\end{tabular}

Médias na mesma coluna seguidas de mesma letra maiúscula não diferem entre si $(P>0,10)$

Médias na mesma linha seguidas de mesma letra minúscula não diferem entre si $(\mathrm{P}>0,10)$

Valores entre parênteses indicam erro padrão da média

$\mathrm{Na}$ condição de pré-pastejo, houve efeito de resíduo $(\mathrm{P}=0,0150)$, interceptação luminosa $(\mathrm{P}=0,0012)$, estrato $(\mathrm{P}=0,0001)$, época do ano $(\mathrm{P}=0,0003)$ e das interações interceptação luminosa $\mathrm{x}$ estrato $(\mathrm{P}=0,1026)$, resíduo $\mathrm{x}$ época do ano $(\mathrm{P}=0,0027)$ e interceptação luminosa $\mathrm{x}$ época do ano $(\mathrm{P}=0,0118)$. Os tratamentos de $95 \%$ IL resultaram em um maior valor de DIVMO (58,1 \%) no momento da entrada dos animais (Tabela 78). Euclides (1993) encontrou valores de DIVMO de 54,2, 54,4, 56,7 para Colonião, Tobiatã e Tanzânia, respectivamente, quando estudava variação na composição bromatológica dos diferentes cultivares. Os valores encontrados por essa autora foram semelhantes aos encontrados neste estudo para os tratamentos de $100 \%$ IL que, na média, resultaram em intervalos entre pastejos semelhantes ao de Euclides (1993). A diferenciação de estrato como "pastejo de ponta e pastejo de fundo" gerou uma diferença de 4 pontos percentuais no valor de DIVMO (Tabela 78). Esses valores confirmaram a sugestão de Hodgson (1990) de que apenas os estratos superiores devam ser pastejados por animais de maior potencial de produção, sendo o restante da forragem destinado a animais de menor exigência nutricional quando o objetivo é melhorar o valor nutritivo da forragem ingerida pelos animais. 
Tabela 78. Digestibilidade in vitro da matéria orgânica nos estratos basal e superior da massa de forragem em pré-pastejo de capim-Mombaça com pastejos realizados a 95 e $100 \%$ de interceptação luminosa do dossel forrageiro durante o período de janeiro de 2001 a fevereiro de 2002

\begin{tabular}{cccc}
\hline & \multicolumn{2}{c}{ Interceptação Luminosa $(\%)$} \\
Estrato & 95 & 100 & Média \\
\hline Basal & $55,4^{\mathrm{aB}}(0,83)$ & $53,7^{\mathrm{aB}}(0,83)$ & $54,5^{\mathrm{B}}(0,58)$ \\
Superior & $60,8^{\mathrm{aA}}(0,83)$ & $56,3^{\mathrm{bA}}(0,83)$ & $58,5^{\mathrm{A}}(0,58)$ \\
Média & $58,1^{\mathrm{a}}(0,58)$ & $55,0^{\mathrm{b}}(0,58)$ & \\
\hline
\end{tabular}

Médias na mesma coluna seguidas de mesma letra maiúscula não diferem entre si $(\mathrm{P}>0,10)$

Médias na mesma linha seguidas de mesma letra minúscula não diferem entre si $(P>0,10)$

Valores entre parênteses indicam erro padrão da média

Para as diferentes épocas do ano estudadas houve uma redução dos valores de DIVMO somente no período outono/inverno, conseqüência da fase de desenvolvimento reprodutivo das plantas (Tabela 79). Em termos de resíduo, os tratamentos com resíduo $30 \mathrm{~cm}$ apresentaram valores menores de DIVMO, exceção feita somente para o verão, época na qual não houve diferença de valores entre as intensidades (Tabela 79).

Tabela 79. Digestibilidade in vitro da matéria orgânica da massa de forragem em prépastejo de capim-Mombaça com pastejos realizados a 30 e $50 \mathrm{~cm}$ de resíduo durante o período de janeiro de 2001 a fevereiro de 2002

\begin{tabular}{|c|c|c|c|}
\hline \multicolumn{4}{|c|}{ Resíduo $(\mathrm{cm})$} \\
\hline Época do ano & 30 & 50 & Média \\
\hline Verão & $58,6^{\mathrm{aA}}(0,42)$ & $57,9^{\mathrm{aB}}(0,42)$ & $58,3^{\mathrm{A}}(0,30)$ \\
\hline Outono/Inverno & $50,3^{\mathrm{bB}}(1,50)$ & $55,0^{\mathrm{aC}}(1,50)$ & $52,7^{\mathrm{B}}(1,06)$ \\
\hline Primavera & $57,3^{\mathrm{bA}}(0,86)$ & $59,9^{\text {aA }}(0,86)$ & $58,6^{\mathrm{A}}(0,61)$ \\
\hline Média & $55,4^{\mathrm{b}}(0,58)$ & $57,6^{\mathrm{a}}(0,58)$ & \\
\hline
\end{tabular}

Médias na mesma coluna seguidas de mesma letra maiúscula não diferem entre si $(\mathrm{P}>0,10)$

Médias na mesma linha seguidas de mesma letra minúscula não diferem entre si $(\mathrm{P}>0,10)$

Valores entre parênteses indicam erro padrão da média 
Mesmo na fase reprodutiva das plantas os valores de DIVMO obtidos nesse experimento foram semelhantes àqueles relatados por Moore \& Mott (1973) quando avaliaram gramíneas tropicais (55 a $60 \%$ ), exceção feita ao resíduo de $30 \mathrm{~cm}$ no outono/inverno, onde a digestibilidade ficou em $50 \%$, refletindo a menor proporção de folhas (cerca de $20 \%$ ) naquela época para os tratamentos de $30 \mathrm{~cm}$ associados a 100\% IL (Tabela 33).

A interação época do ano $\mathrm{x}$ interceptação luminosa ocorreu porque no outono/inverno não houve diferença para a DIVMO em função dos diferentes intervalos entre pastejos (95 e 100\% IL), enquanto que para as outras épocas do ano os tratamentos com menor intervalo entre pastejos sempre apresentaram maiores valores de DIVMO (Tabela 80). Esses resultados corroboram aqueles de Braga (2001), que também encontrou maiores valores de digestibilidade in vitro da matéria seca (DIVMS) para intervalos de descanso mais curtos $(56,3 \times 53,1 \%)$.

Tabela 80. Digestibilidade in vitro da matéria orgânica da massa de forragem em prépastejo de capim-Mombaça com pastejos realizados a 95 e $100 \%$ de interceptação luminosa do dossel forrageiro durante o período de janeiro de 2001 a fevereiro de 2002

\begin{tabular}{cccc}
\hline & \multicolumn{2}{c}{ Interceptação Luminosa $(\%)$} & Média \\
\hline Época do ano & 95 & 100 & $58,3^{\mathrm{A}}(0,30)$ \\
\hline Verão & $59,9^{\mathrm{aB}}(0,42)$ & $56,6^{\mathrm{bA}}(0,42)$ & $52,7^{\mathrm{B}}(1,06)$ \\
Outono/Inverno & $52,4^{\mathrm{aC}}(1,50)$ & $53,0^{\mathrm{aB}}(1,50)$ & $58,6^{\mathrm{A}}(0,61)$ \\
Primavera & $61,9^{\mathrm{aA}}(0,86)$ & $55,3^{\mathrm{bAB}}(0,86)$ & \\
Média & $58,1^{\mathrm{a}}(0,58)$ & $55,0^{\mathrm{b}}(0,58)$ & \\
\hline
\end{tabular}

Médias na mesma coluna seguidas de mesma letra maiúscula não diferem entre si $(\mathrm{P}>0,10)$

Médias na mesma linha seguidas de mesma letra minúscula não diferem entre si $(P>0,10)$

Valores entre parênteses indicam erro padrão da média

Durante o período de outono/inverno, houve efeito de resíduo $(\mathrm{P}=0,0131)$ e estrato $(\mathrm{P}=0,0942)$. Os tratamentos com $50 \mathrm{~cm}$ de resíduo apresentaram um valor de DIVMO 4 unidades percentuais superior àquele dos tratamentos com $30 \mathrm{~cm}$ de resíduo 


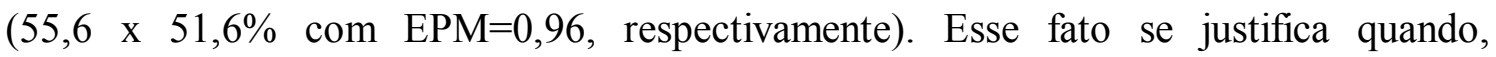
analisando os resultados de material vivo, nota-se que os tratamentos com $50 \mathrm{~cm}$ de resíduo apresentaram uma proporção 3,7 unidades percentuais superior àquela de $30 \mathrm{~cm}$ de resíduo quando submetidos às mesmas condições.

$\mathrm{Na}$ fase de desenvolvimento reprodutivo das plantas, o estrato basal apresentou menor valor de DIVMO e não houve diferença entre os valores do estrato mediano e superior (Tabela 81). Nesse período, apesar do estrato superior ter maior proporção de material vivo (Tabela 27), esse valor era composto por 12,5 unidades percentuais a mais de hastes florescidas do que no estrato mediano (Tabela 48). Esses valores confirmam a afirmação feita por Nelson \& Mozzer (1994) de que a maturidade das plantas contribui com o aumento da parede celular, porém o declínio no valor nutritivo da forragem está atribuído ao decréscimo da relação folha:haste e ao declínio da qualidade da haste.

Tabela 81. Digestibilidade in vitro da matéria orgânica nos estratos basal, mediano e superior da massa de forragem em pré-pastejo de capim-Mombaça submetido a combinações de intervalos entre pastejos (IL) e intensidades de pastejo (altura do resíduo) durante o período de abril de 2001 a setembro de 2001

\begin{tabular}{cc}
\hline Estrato & $\%$ DIVMO \\
\hline Basal & $51,2^{\mathrm{B}}(1,18)$ \\
Mediano & $54,2^{\mathrm{A}}(1,18)$ \\
Superior & $54,7^{\mathrm{A}}(1,18)$ \\
Média & 53,4
\end{tabular}

Médias na mesma coluna seguidas de mesma letra maiúscula não diferem entre si $(\mathrm{P}>0,10)$ Valores entre parênteses indicam erro padrão da média 


\subsubsection{Lignina}

$\mathrm{Na}$ fase de rebrotação, houve efeito de resíduo $(\mathrm{P}=0,0507)$, interceptação luminosa $(\mathrm{P}=0,0086)$, altura do dossel $(\mathrm{P}=0,0476)$, época do ano $(\mathrm{P}=0,0698)$ e das interações resíduo x interceptação luminosa $(\mathrm{P}=0,0224)$, interceptação luminosa $\mathrm{x}$ altura do dossel $(\mathrm{P}=0,0224)$, resíduo $\mathrm{x}$ época do ano $(\mathrm{P}=0,0174)$, interceptação luminosa $\mathrm{x}$ época do ano $(\mathrm{P}=0,0193)$ e altura do dossel $\mathrm{x}$ época do ano $(\mathrm{P}=0,0908)$. Os tratamentos de resíduo de $50 \mathrm{~cm}$ e de pastejos realizados a $95 \%$ IL apresentaram os maiores teores de lignina (Tabela 82). Provavelmente essa elevação foi ocasionada pelo maior valor de lignina obtido para o tratamento 50/95, refletindo o aumento da proporção de hastes que ocorreu no período de verão para esse tratamento em relação ao tratamento 30/95 (Tabela 36).

Tabela 82. Porcentagem de lignina na massa de forragem durante a rebrotação de capimMombaça submetido a combinações de intervalos entre pastejos (IL) e intensidades de pastejo (altura do resíduo) durante o período de janeiro de 2001 a fevereiro de 2002

\begin{tabular}{cccc}
\hline & \multicolumn{2}{c}{ Interceptação Luminosa $(\%)$} & Média \\
Resíduo $(\mathrm{cm})$ & 95 & 100 & $5,3^{\mathrm{B}}(0,17)$ \\
\hline 30 & $5,4^{\mathrm{aB}}(0,24)$ & $5,2^{\mathrm{aA}}(0,24)$ & $5,8^{\mathrm{A}}(0,17)$ \\
50 & $6,4^{\mathrm{aA}}(0,24)$ & $5,2^{\mathrm{bA}}(0,31)$ & \\
Média & $5,9^{\mathrm{a}}(0,17)$ & $5,2^{\mathrm{b}}(0,19)$ & \\
\hline
\end{tabular}

Médias na mesma coluna seguidas de mesma letra maiúscula não diferem entre si $(\mathrm{P}>0,10)$

Médias na mesma linha seguidas de mesma letra minúscula não diferem entre si $(\mathrm{P}>0,10)$

Valores entre parênteses indicam erro padrão da média

A interação interceptação luminosa $\mathrm{x}$ altura do dossel (fase de rebrotação) ocorreu porque houve um aumento no valor de lignina nas avaliações de $+20 \mathrm{~cm}$ para pastejos realizados a $95 \%$ IL (Tabela 83 ). 
Tabela 83. Porcentagem de lignina na massa de forragem durante a rebrotação de capimMombaça com pastejos realizados a 95 e 100 \% de interceptação luminosa do dossel forrageiro durante o período de janeiro de 2001 a fevereiro de 2002

\begin{tabular}{cccc}
\hline \multirow{2}{*}{ Interceptação Luminosa $(\%)$} & +20 & +40 & Média \\
\hline 95 & $6,5^{\mathrm{aA}}(0,24)$ & $5,3^{\mathrm{bA}}(0,24)$ & $5,9^{\mathrm{A}}(0,17)$ \\
100 & $5,1^{\mathrm{aB}}(0,24)$ & $5,2^{\mathrm{aA}}(0,31)$ & $5,2^{\mathrm{B}}(0,19)$ \\
Média & $5,8^{\mathrm{a}}(0,16)$ & $5,3^{\mathrm{b}}(0,19)$ & \\
\hline
\end{tabular}

Médias na mesma coluna seguidas de mesma letra maiúscula não diferem entre si $(P>0,10)$

Médias na mesma linha seguidas de mesma letra minúscula não diferem entre si $(P>0,10)$

Valores entre parênteses indicam erro padrão da média

Em relação à época do ano, o verão apresentou maior valor de lignina quando comparado aos períodos de outono/inverno e primavera (Tabela 84). A interação resíduo x época do ano ocorreu em função da inversão de comportamento das médias para 30 e $50 \mathrm{~cm}$ de resíduo durante o outono/inverno (Tabela 84 ).

Tabela 84. Porcentagem de lignina na massa de forragem durante a rebrotação de capimMombaça com pastejos realizados a 30 e $50 \mathrm{~cm}$ de resíduo durante o período de janeiro de 2001 a fevereiro de 2002

\begin{tabular}{cccc}
\hline & \multicolumn{2}{c}{ Resíduo $(\mathrm{cm})$} & Média \\
\hline Época do ano & 30 & 50 & $6,1^{\mathrm{A}}(0,23)$ \\
\hline Verão & $5,5^{\mathrm{bAB}}(0,33)$ & $6,6^{\mathrm{aA}}(0,33)$ & $5,3^{\mathrm{B}}(0,27)$ \\
Outono/Inverno & $5,6^{\mathrm{aB}}(0,33)$ & $5,0^{\mathrm{aB}}(0,43)$ & $5,3^{\mathrm{B}}(0,23)$ \\
Primavera & $4,7^{\mathrm{bA}}(0,33)$ & $5,8^{\mathrm{aAB}}(0,33)$ & \\
Média & $5,3^{\mathrm{b}}(0,17)$ & $5,8^{\mathrm{a}}(0,19)$ & \\
\hline
\end{tabular}

Médias na mesma coluna seguidas de mesma letra maiúscula não diferem entre si $(\mathrm{P}>0,10)$

Médias na mesma linha seguidas de mesma letra minúscula não diferem entre si $(\mathrm{P}>0,10)$

Valores entre parênteses indicam erro padrão da média

A interação interceptação luminosa $\mathrm{x}$ época do ano aconteceu porque os pastejos realizados a $100 \%$ IL do dossel forrageiro não apresentaram diferença nos valores de 
lignina ao longo do ano (Tabela 85), refletindo a ausência de variação também nas proporções de hastes (Tabela 36). O mesmo aconteceu para as avaliações de rebrotação na altura $+40 \mathrm{~cm}$ (Tabela 86$)$.

Tabela 85. Porcentagem de lignina na massa de forragem durante a rebrotação de capimMombaça com pastejos realizados a 95 e $100 \%$ de interceptação luminosa do dossel forrageiro durante o período de janeiro de 2001 a fevereiro de 2002

\begin{tabular}{cccc}
\hline & \multicolumn{3}{c}{ Resíduo $(\mathrm{cm})$} \\
Época do ano & 30 & 50 & Média \\
\hline Verão & $6,9^{\mathrm{aA}}(0,33)$ & $5,2^{\mathrm{bA}}(0,33)$ & $6,1^{\mathrm{A}}(0,23)$ \\
Outono/Inverno & $5,2^{\mathrm{aB}}(0,33)$ & $5,5^{\mathrm{aA}}(0,43)$ & $5,3^{\mathrm{B}}(0,27)$ \\
Primavera & $5,7^{\mathrm{aB}}(0,33)$ & $4,9^{\mathrm{bA}}(0,33)$ & $5,3^{\mathrm{B}}(0,23)$ \\
Média & $5,9^{\mathrm{a}}(0,17)$ & $5,2^{\mathrm{b}}(0,19)$ &
\end{tabular}

Médias na mesma coluna seguidas de mesma letra maiúscula não diferem entre si $(\mathrm{P}>0,10)$

Médias na mesma linha seguidas de mesma letra minúscula não diferem entre si $(P>0,10)$

Valores entre parênteses indicam erro padrão da média

Tabela 86. Porcentagem de lignina na massa de forragem durante a rebrotação de capimMombaça submetido a combinações de intervalos entre pastejos (IL) e intensidades de pastejo (altura do resíduo) durante o período de janeiro de 2001 a fevereiro de 2002

\begin{tabular}{cccc}
\hline & \multicolumn{2}{c}{ Fase de Rebrotação } & \\
Época do ano & +20 & +40 & Média \\
\hline Verão & $6,8^{\mathrm{aA}}(0,33)$ & $5,3^{\mathrm{bA}}(0,33)$ & $6,1^{\mathrm{A}}(0,23)$ \\
Outono/Inverno & $5,5^{\mathrm{aB}}(0,33)$ & $5,1^{\mathrm{aA}}(0,43)$ & $5,3^{\mathrm{B}}(0,27)$ \\
Primavera & $5,1^{\mathrm{aB}}(0,33)$ & $5,4^{\mathrm{aA}}(0,33)$ & $5,3^{\mathrm{B}}(0,23)$ \\
Média & $5,8^{\mathrm{a}}(0,16)$ & $5,3^{\mathrm{b}}(0,19)$ & \\
\hline
\end{tabular}

Médias na mesma coluna seguidas de mesma letra maiúscula não diferem entre si $(\mathrm{P}>0,10)$

Médias na mesma linha seguidas de mesma letra minúscula não diferem entre si $(P>0,10)$

Valores entre parênteses indicam erro padrão da média 
$\mathrm{Na}$ condição de pré-pastejo, houve efeito de resíduo $(\mathrm{P}=0,0017)$ e da interação resíduo x interceptação luminosa $(\mathrm{P}=0,0249)$. Os pastejos realizados a 95 e $100 \%$ IL não resultaram em diferenças nos teores de lignina. Já em relação ao resíduo, o resíduo de $50 \mathrm{~cm}$ apresentou maior valor de lignina do que o resíduo de $30 \mathrm{~cm}$ (Tabela 87). A interação resíduo x interceptação luminosa ocorreu porque os tratamentos com $100 \%$ IL não geraram diferenças nos teores de lignina quando associados aos resíduos de 30 e 50 cm. Já os tratamentos com 95\% IL associados ao resíduo de $50 \mathrm{~cm}$ elevaram o valor de lignina em cerca de 1 ponto percentual. No período do outono/inverno não houve efeito das condições impostas ao dossel forrageiro. A média geral do experimento foi de 5,2\%.

Tabela 87. Porcentagem de lignina na massa de forragem em pré-pastejo de capimMombaça submetido a combinações de intervalos entre pastejos (IL) e intensidades de pastejo (altura do resíduo) durante o período de janeiro de 2001 a fevereiro de 2002

\begin{tabular}{cccc}
\hline Resíduo $(\mathrm{cm})$ & \multicolumn{2}{c}{ Interceptação Luminosa $(\%)$} & Média \\
\hline 30 & 95 & 100 & $4,6^{\mathrm{B}}(0,14)$ \\
50 & $4,5^{\mathrm{aB}}(0,19)$ & $4,7^{\mathrm{aA}}(0,19)$ & $5,3^{\mathrm{A}}(0,14)$ \\
Média & $5,7^{\mathrm{aA}}(0,19)$ & $4,9^{\mathrm{bA}}(0,19)$ & \\
& $5,1(0,14)$ & $4,8(0,14)$ & \\
\hline
\end{tabular}

Médias na mesma coluna seguidas de mesma letra maiúscula não diferem entre si $(\mathrm{P}>0,10)$

Médias na mesma linha seguidas de mesma letra minúscula não diferem entre si $(\mathrm{P}>0,10)$

Valores entre parênteses indicam erro padrão da média

\subsection{Produção de forragem}

\subsubsection{Taxas de acúmulo de massa seca}

As taxas mensais de acúmulo de massa seca de forragem são apresentadas na Tabela 88. Foram obtidos efeitos de mês do ano $(\mathrm{P}<0,0001)$ e das interações interceptação luminosa x mês do ano $(\mathrm{P}=0,0055)$, resíduo x mês do ano $(\mathrm{P}=0,0048)$ e interceptação luminosa $x$ resíduo x mês do ano $(\mathrm{P}=0,0620)$. Os tratamentos de $95 \%$ de interceptação luminosa superaram os tratamentos de 100\% durante os meses de janeiro e 
fevereiro. Santos (1997) observou taxas de acúmulo líquido decrescentes de 28 para 48 dias de intervalo entre pastejos no período de novembro a abril, sendo essa redução mais expressiva entre 28 e 38 dias, e no período de maio a setembro as taxas de acúmulo tenderam a aumentar com o intervalo entre pastejos, resultado, provavelmente, do desenvolvimento reprodutivo das plantas naquelas condições.

Nos outros meses do ano as taxas de acúmulo foram praticamente iguais $(\mathrm{P}>0,10)$ (Tabela 88). Nos meses de outono/inverno e em dezembro, os tratamentos de $30 \mathrm{~cm}$ de resíduo apresentaram taxas de acúmulo superiores àquelas dos tratamentos de $50 \mathrm{~cm}$. Nos demais meses essa diferença não existiu $(\mathrm{P}>0,10)$.

Tabela 88. Taxas mensais de acúmulo de forragem $\left(\mathrm{kgMS} \cdot \mathrm{ha}^{-1} \cdot \mathrm{dia}^{-1}\right)$ para capimMombaça submetido a combinações de intervalos entre pastejos (IL) e intensidades de pastejo (altura do resíduo) durante o período de abril de 2001 a setembro de 2001

\begin{tabular}{ccccc}
\hline \multicolumn{5}{c}{ Interceptação Luminosa (\%) } \\
Resíduo (cm) & 95 & 100 & Média & Média Mensal \\
\hline \multicolumn{5}{c}{ Janeiro } \\
30 & $147^{\mathrm{aA}}(19,7)$ & $118^{\mathrm{bA}}(19,7)$ & $132^{\mathrm{A}}(14,0)$ & \\
50 & $133^{\mathrm{aA}}(19,7)$ & $103^{\mathrm{bA}}(19,7)$ & $118^{\mathrm{A}}(14,0)$ & $125^{\mathrm{A}^{\prime}}$ \\
Média & $140^{\mathrm{a}}(14,0)$ & $110^{\mathrm{b}}(14,0)$ & & \\
50 & $103^{\mathrm{aB}}(28,9)$ & $88^{\mathrm{bA}}(28,9)$ & $95^{\mathrm{A}}(20,4)$ & \\
50 & $164^{\mathrm{aA}}(28,9)$ & $72^{\mathrm{bA}}(28,9)$ & $118^{\mathrm{A}}(20,4)$ & $107^{\mathrm{B}}$ \\
Média & $134^{\mathrm{a}}(20,4)$ & $80^{\mathrm{b}}(20,4)$ & & \\
30 & $112^{\mathrm{aA}}(16,0)$ & $109^{\mathrm{aA}}(16,0)$ & $111^{\mathrm{A}}(11,3)$ & \\
50 & $70^{\mathrm{aB}}(16,0)$ & $76^{\mathrm{aB}}(16,0)$ & $73^{\mathrm{B}}(11,3)$ & $92^{\mathrm{B}^{\prime} \mathrm{C}^{\prime}}$ \\
Média & $91^{\mathrm{a}}(11,3)$ & $92^{\mathrm{a}}(11,3)$ & & \\
30 & $64^{\mathrm{aA}}(28,2)$ & $72^{\mathrm{aA}}(28,2)$ & $68^{\mathrm{A}}(19,9)$ & \\
50 & $73^{\mathrm{aA}}(28,2)$ & $100^{\mathrm{aA}}(28,2)$ & $86^{\mathrm{A}}(19,9)$ & $77^{\mathrm{C}^{\prime}}$ \\
Média & $68^{\mathrm{a}}(19,9)$ & $86^{\mathrm{a}}(19,9)$ & & \\
30 & $42^{\mathrm{aA}}(7,6)$ & $30^{\mathrm{aA}}(7,6)$ & $36^{\mathrm{A}}(5,4)$ & \\
50 & $21^{\mathrm{aB}}(7,6)$ & $20^{\mathrm{aA}}(7,6)$ & $21^{\mathrm{B}}(5,4)$ & $28^{\mathrm{D}^{\prime}} \mathrm{E}^{\prime}$ \\
Média & $32^{\mathrm{a}}(5,4)$ & $25^{\mathrm{a}}(5,4)$ & & \\
\hline
\end{tabular}




\begin{tabular}{|c|c|c|c|c|}
\hline \multicolumn{4}{|c|}{ Junho } & \multirow{4}{*}{$25^{\mathrm{D}^{\prime}}$} \\
\hline 30 & $30^{\mathrm{aA}}(5,0)$ & $30^{\mathrm{aA}}(5,0)$ & $30^{\mathrm{A}}(3,6)$ & \\
\hline 50 & $21^{\mathrm{aA}}(5,0)$ & $20^{\mathrm{aA}}(5,0)$ & $21^{\mathrm{B}}(3,6)$ & \\
\hline Média & $26^{\mathrm{a}}(3,6)$ & $25^{\mathrm{a}}(3,6)$ & & \\
\hline \multicolumn{4}{|c|}{ Julho } & \multirow{4}{*}{$24^{\mathrm{D}^{\prime}}$} \\
\hline 30 & $26^{\mathrm{aA}}(3,7)$ & $33^{\mathrm{aA}}(3,7)$ & $29^{\mathrm{A}}(2,6)$ & \\
\hline 50 & $18^{\mathrm{aA}}(3,7)$ & $20^{\mathrm{aA}}(3,7)$ & $19^{\mathrm{B}}(2,6)$ & \\
\hline Média & $22^{\mathrm{a}}(2,6)$ & $27^{\mathrm{a}}(2,6)$ & & \\
\hline \multicolumn{4}{|c|}{ Agosto } & \multirow{4}{*}{$24^{D^{\prime}}$} \\
\hline 30 & $21^{\mathrm{bA}}(3,1)$ & $40^{\mathrm{aA}}(3,1)$ & $30^{\mathrm{A}}(2,2)$ & \\
\hline 50 & $15^{\mathrm{aA}}(3,1)$ & $20^{\mathrm{aB}}(3,1)$ & $18^{\mathrm{B}}(2,2)$ & \\
\hline Média & $18^{\mathrm{a}}(2,2)$ & $30^{\mathrm{a}}(2,2)$ & & \\
\hline \multicolumn{4}{|c|}{ Setembro } & \multirow{4}{*}{$25^{D^{\prime}}$} \\
\hline 30 & $21^{\mathrm{bA}}(3,7)$ & $45^{\mathrm{aA}}(3,7)$ & $32^{\mathrm{A}}(2,6)$ & \\
\hline 50 & $15^{\mathrm{aA}}(3,7)$ & $20^{\mathrm{aB}}(3,7)$ & $18^{\mathrm{B}}(2,6)$ & \\
\hline \multirow[t]{2}{*}{ Média } & $18^{\mathrm{b}}(2,6)$ & $33^{\text {a }}(2,6)$ & & \\
\hline & \multicolumn{2}{|c|}{ Outubro } & & \\
\hline 30 & $38^{\mathrm{aA}}(12,6)$ & $45^{\mathrm{aA}}(12,6)$ & $41^{\mathrm{A}}(8,9)$ & \\
\hline 50 & $39^{\mathrm{aA}}(12,6)$ & $31^{\mathrm{aA}}(12,6)$ & $35^{\mathrm{A}}(8,9)$ & $38^{\mathrm{E}}$ \\
\hline \multirow[t]{2}{*}{ Média } & $39^{\mathrm{a}}(8,9)$ & $38^{\mathrm{a}}(8,9)$ & & \\
\hline & \multicolumn{2}{|c|}{ Novembro } & & \\
\hline 30 & $91^{\mathrm{aA}}(15,2)$ & $76^{\mathrm{aA}}(15,2)$ & $83^{\mathrm{A}}(10,7)$ & \\
\hline 50 & $50^{\mathrm{aA}}(15,2)$ & $78^{\mathrm{aA}}(15,2)$ & $64^{\mathrm{A}}(10,7)$ & $74^{C}$ \\
\hline \multirow[t]{2}{*}{ Média } & $70^{a}(10,7)$ & $77^{\mathrm{a}}(10,7)$ & & \\
\hline & \multicolumn{2}{|c|}{ Dezembro } & & \\
\hline 30 & $148^{\mathrm{aA}}(19,2)$ & $114^{\mathrm{bA}}(19,2)$ & $131^{\mathrm{A}}(13,6)$ & \\
\hline 50 & $56^{\mathrm{bB}}(19,2)$ & $105^{\mathrm{aA}}(19,2)$ & $81^{\mathrm{B}}(13,6)$ & $106^{\mathrm{A}^{\prime} \mathrm{B}^{\prime}}$ \\
\hline Média & $102^{\mathrm{a}}(13,6)$ & $109^{\mathrm{a}}(13,6)$ & & \\
\hline
\end{tabular}

Médias na mesma coluna seguidas de mesma letra maiúscula não diferem entre si $(\mathrm{P}>0,10)$

Médias na mesma linha seguidas de mesma letra minúscula não diferem entre si $(P>0,10)$

Médias mensal seguidas de mesma letra maiúscula acrescidas de (') não diferem entre si $(\mathrm{P}>0,10)$

Valores entre parênteses correspondem ao erro padrão da média

As maiores taxas de acúmulo foram observadas nos meses de verão, seguidas dos meses da primavera e revelando acentuada estacionalidade de produção, típica desse cultivar de P. maximum (Figura 17) nos meses de maior disponibilidade de fatores de crescimento (dezembro a março). Reduções observadas a partir do mês de abril refletiram o início do estádio reprodutivo, já que o desenvolvimento da inflorescência nos perfilhos leva ao cessamento da emissão de novas folhas podendo inibir, ainda, o aparecimento de novos perfilhos, o que levaria a uma subseqüente redução da produção do pasto (Cooper, 1983). 


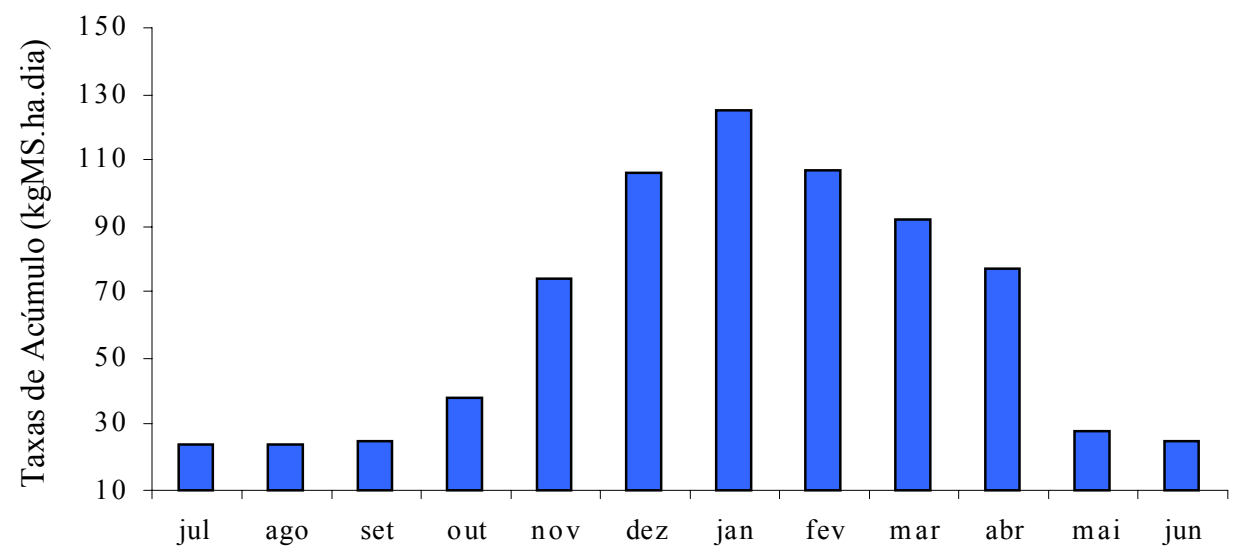

Figura 17 - Médias mensais das taxas de acúmulo de forragem no capim-Mombaça

\subsubsection{Acúmulo total de massa seca}

O acúmulo de massa seca foi obtido através do corte da massa de forragem em pós e pré-pastejos sucessivos e os valores obtidos por pastejo foram agrupados por época do ano. Houve efeito de época do ano $(\mathrm{P}=0,0001)$ e resíduo $(\mathrm{P}=0,0235)$, além da interação interceptação luminosa x época do ano $(\mathrm{P}=0,1027)$. Os tratamentos de resíduo $30 \mathrm{~cm}$ resultaram no maior acúmulo de forragem do experimento (Tabela 89). A maior produção de forragem medida foi a do tratamento 30/95 que, no entanto, não diferiu do tratamento 30/100 ( $\mathrm{P}>0,10)$. Os tratamentos de 95\% de IL acumularam cerca de 2.000 $\mathrm{kg} \mathrm{MS} \cdot \mathrm{ha}^{-1}$ de forragem a mais que os tratamentos de $100 \%$ de IL, porém as média foram semelhantes $(\mathrm{P}>0,10)$. Esses resultados demonstraram a maior importância da intensidade relativamente ao intervalo entre pastejos, certamente conseqüência de sua influência sobre a eficiência de utilização da forragem produzida. $O$ intervalo entre pastejos seria um otimizador da resposta à intensidade de desfolhação, controlando a estrutura do dossel (relação vivo:morto e folha:haste) e o valor nutritivo da forragem produzida. Exemplo disso foi a dificuldade de manutenção do resíduo de $30 \mathrm{~cm}$ no tratamento 30/100 neste experimento.

Santos (2002), trabalhando com capim-Tanzânia, observou maior renovação da população de perfilhos nos tratamentos submetidos a alta intensidade de desfolhação, 
sendo que os perfilhos com mais de 100 dias de vida representavam cerca de $13 \%$ apenas da massa de forragem total, enquanto que nos tratamentos de baixa intensidade de desfolhação esse número subiu para cerca de 33\%. Korte et al. (1984), trabalhando com azevém perene, observaram que os perfilhos novos contribuíam mais para a produção de forragem no pastejo mais intenso do que no pastejo mais leniente. Entretanto, Gomes (2001), em estudo com capim-Mombaça, obteve maior produção de forragem com a menor intensidade de desfolhação estudada (oferta de $12 \%$ do peso animal), resultado, contudo, do aumento do acúmulo de hastes em relação a lâminas foliares.

Tabela 89. Acúmulo de massa seca de forragem $\left(\mathrm{kg}\right.$ MS.ha $\left.{ }^{-1}\right)$ de capim-Mombaça submetido a combinações de intervalos entre pastejos (IL) e intensidades de pastejo (altura do resíduo) durante o período de janeiro de 2001 a fevereiro de 2002

\begin{tabular}{cccc}
\hline Resíduo (cm) & \multicolumn{3}{c}{ Interceptação Luminosa (\%) } \\
& 95 & 100 & Média \\
\hline 30 & 26.910 & 24.900 & $25.900^{\mathrm{A}}(1.764)$ \\
50 & 17.910 & 20.280 & $19.100^{\mathrm{B}}(1.764)$ \\
Média & $24.410^{\mathrm{a}}$ & $22.590^{\mathrm{a}}$ & 23.500 \\
\hline
\end{tabular}

Médias na mesma coluna seguidas de mesma letra maiúscula não diferem entre si $(\mathrm{P}>0,10)$ Médias na mesma linha seguidas de mesma letra maiúscula não diferem entre si $(\mathrm{P}>0,10)$ Valores entre parênteses correspondem ao erro padrão da média

Com relação às épocas do ano, a maior produção de forragem foi observada no verão e as menores durante o outono/inverno (Tabela 90). Cecato et al. (1996) obtiveram $81 \%$ da produção do capim-Mombaça no período de crescimento vegetativo. 
Tabela 90. Acúmulo total de massa seca $\left(\mathrm{kg} \cdot \mathrm{ha}^{-1}\right)$ de capim-Mombaça para pastejos realizados 30 e $50 \mathrm{~cm}$ de resíduo durante o período de janeiro 2001 a fevereiro de 2002

\begin{tabular}{ccccc}
\hline & \multicolumn{2}{c}{ Resíduo $(\mathrm{cm})$} & & \\
Época do ano & 30 & 50 & Média & $\%$ \\
\hline Primavera & $7.920^{\mathrm{aB}}(661,3)$ & $5.330^{\mathrm{bB}}(661,3)$ & $6.620^{\mathrm{B}}(467,6)$ & 29,2 \\
Verão & $11.070^{\mathrm{aA}}(661,3)$ & $8.680^{\mathrm{bA}}(661,3)$ & $9.880^{\mathrm{A}}(467,6)$ & 43,6 \\
Outono & $4.050^{\mathrm{aC}}(661,3)$ & $3.760^{\mathrm{aC}}(661,3)$ & $3.900^{\mathrm{C}}(467,6)$ & 17,2 \\
Inverno & $3.020^{\mathrm{aC}}(661,3)$ & $1.540^{\mathrm{aD}}(661,3)$ & $2.280^{\mathrm{D}}(467,6)$ & 10,0 \\
Média & $6.510^{\mathrm{a}}(330,6)$ & $4.830^{\mathrm{b}}(330,6)$ & & \\
\hline
\end{tabular}

Médias na mesma linha seguidas da mesma letra minúscula não diferem entre si $(\mathrm{P}>0,10)$

Médias na mesma coluna seguidas da mesma letra maiúscula não diferem entre si $(\mathrm{P}>0,10)$

Valores entre parênteses correspondem ao erro padrão da média

Não houve efeito de interceptação luminosa (condição para o início do pastejo) $(\mathrm{P}=0$,9614) (Tabela 91), resultado semelhante ao de Braga (2001), que também não observou diferenças em produção de forragem do capim-Mombaça para os intervalos entre cortes de 28 e 42 dias. O mesmo comportamento foi obtido por Correa et al. (1998) em estudo com 12 gramíneas forrageiras tropicais, no qual observaram redução da produção de massa seca por corte com a diminuição da idade das plantas. Porém, quando considerou-se a produção total de massa seca do período experimental, as diferenças não foram acentuadas ou não existiram, pois as menores produções por corte foram compensadas pelo maior número de colheitas nos cortes mais freqüentes. Já Herling et al. (1998b) obtiveram maior produção de massa seca verde com intervalo entre desfolhações de 35 dias em relação ao de 42 dias, e maior quantidade de forragem (massa seca total) para o intervalo entre desfolhações de 42 dias, em estudo com capimMombaça, indicando que o diferencial positivo em favor do intervalo de 42 dias foi devido ao acúmulo de material morto. A porcentagem média de folhas e hastes no material vivo foi $60 \%$ e $40 \%$, respectivamente, não havendo diferença entre os intervalos de desfolhação estudados. 
Carvalho et al. (2000), trabalhando com cinco gramíneas forrageiras tropicais, encontraram taxas de acúmulo de forragem semelhantes para os intervalos entre cortes de 30 e 45 dias, mas o maior teor de fibra insolúvel em detergente neutro (FDN) foi determinado para cortes aos 42 por Oliveira et al. (2001). Costa et al. (1997) estudaram a produção de massa seca do capim-Tobiatã submetido a seis idades de corte $(28,42,56$, 70, 84, 98 dias) e observaram aumento da produção com a idade das plantas. Revelaram, também, redução drástica nos teores de proteína bruta $(\mathrm{PB})$ e na digestibilidade in vitro da forragem a partir de 42 dias, revelando que o aumento em produção além desse período de crescimento era conseqüência, principalmente, do acúmulo de hastes e material morto. Esses resultados apontam para o risco potencial de colheita atrasada sobre o valor nutritivo da forragem, indicando que os benefícios da maior produção de massa seca podem ser negados em função do maior acúmulo de material morto e hastes, menor valor nutritivo da forragem e maior ocorrência de perdas do pastejo.

Tabela 91. Acúmulo de massa seca de forragem (kg MS.ha $\left.{ }^{-1}\right)$ de capim-Mombaça para pastejos realizados a 95 e $100 \%$ de interceptação luminosa durante o período de janeiro de 2001 a fevereiro de 2002

\begin{tabular}{cccc}
\hline & \multicolumn{4}{c}{ Interceptação Luminosa $(\%)$} \\
Época do ano & 95 & 100 & Média \\
\hline Verão & $10.680^{\mathrm{aA}}(785)$ & $9.180^{\mathrm{aA}}(785)$ & $9.930^{\mathrm{A}}(555)$ \\
Outono/Inverno & $5.250^{\mathrm{bA}}(785)$ & $6.550^{\mathrm{bA}}(785)$ & $5.900^{\mathrm{B}}(555)$ \\
Primavera & $6.480^{\mathrm{bA}}(785)$ & $9.860^{\mathrm{bA}}(785)$ & $6.670^{\mathrm{B}}(555)$ \\
Média & 22.410 & 25.590 &
\end{tabular}

Médias na mesma coluna seguidas de mesma letra maiúscula não diferem entre si $(\mathrm{P}>0,10)$

Médias na mesma linha seguidas de mesma letra minúscula não diferem entre si $(\mathrm{P}>0,10)$

Valores entre parênteses indicam erro padrão da média 


\section{CONCLUSÕES}

Com base nos resultados obtidos foi possível elaborar as seguintes conclusões:

- A intensidade de pastejo possui um efeito mais determinante que a freqüência de desfolhação sobre a produção de forragem em pastos de capim-Mombaça;

- O controle da estrutura do dossel e do valor nutritivo da forragem produzida foi mais efetivo na condição de pastejos realizados a $95 \%$ IL a $30 \mathrm{~cm}$ de resíduo;

- O controle deficiente da estrutura do dossel, particularmente no verão e outono, interfere negativamente na produção de forragem da primavera, compromentendo a produção anual da planta;

- A desfolhação intermitente do capim-Mombaça deve ser realizada quando o dossel forrageiro atinge $90 \mathrm{~cm}$ de altura (95\% IL) e o pastejo encerrado quando o resíduo de $30 \mathrm{~cm}$ é atingido. 


\section{REFERÊNCIAS BIBLIOGRÁFICAS}

ANDRADE, J.B. Estudo comparativo de 3 capins da espécie Panicum maximum Jacq. (colonião, tobiatã e K-187-B). Piracicaba, 1987. 133p. Dissertação (Mestrado) Escola Superior de Agricultura "Luiz de Queiroz", Universidade de São Paulo.

ASSOCIATION OF OFFICIAL ANALYTICAL CHEMISTS. Official Methods of Analysis. 15.ed. Washington, 1990. 1298p.

BALSALOBRE, M. A. A. Desempenho de vacas em lactação sob pastejo rotacionado de capim elefante (Pennisetum purpureum Schum.). Piracicaba, 1996, 139p. Dissertação (Mestrado) - Escola Superior de Agricultura "Luiz de Queiroz", Universidade de São Paulo.

BALSALOBRE, M. A. A. Valor alimentar do capim Tanzânia irrigado. Piracicaba, 2002, 113p. Tese (Doutorado) - Escola Superior de Agricultura "Luiz de Queiroz", Universidade de São Paulo.

BARBOSA, M.A.A.F.; DAMASCENO, J.C.; CECATO, U.; SAKAGUTI, E..S. Estudo de perfilhamento em 4 cultivares de Panicum maximum Jacq. submetidos à duas alturas de corte. In: REUNIÃO ANUAL DA SOCIEDADE BRASILEIRA DE ZOOTECNIA, 33., Fortaleza, 1996. Anais. Fortaleza: SBZ, 1996. p. 109-111.

BLASER, R. E.; BRYANT, H. T.; HAMMES Jr., R. C.; BOMAN, R. L.; FONTENOT, J. P.; POLAN, C. E. Managing forages for animal production. Virginia: Polytechnic Institute, 1969. (Research Division Bulletin, 45).

BLASER, R. E. Pasture - animal management to evaluate plants and to develop forage systems. In: SIMPÓSIO SOBRE MANEJO DA PASTAGEM, 9., Piracicaba, 1988. Anais. Piracicaba: FEALQ, 1988. p.1-40. 
BRAGA, G. J. Resposta do capim-Mombaça (Panicum maximum Jacq.) a diferentes doses de nitrogênio e intervalos de corte. Pirassununga, 2001. 122p. Dissertação (Mestrado) - Faculdade de Zootecnia e Engenharia de Alimentos, Universidade de São Paulo.

BRÂNCIO P. A. Composição botânica e qualidade da dieta de bovinos em pastagem nativa dos cerrados submetida a queima. Viçosa, 1996. 117p. Dissertação (Mestrado) - Universidade Federal de Viçosa.

BRÂNCIO, P. A., EUCLIDES, V. P. B., NASCIMENTO JÚNIOR, D. Avaliação de três cultivares de Panicum maximum Jacq. sob pastejo. 2. Proporções de folha, talo e material morto da pastagem e seletividade em pastejo (compact disc). In: REUNIÃO ANUAL DA SOCIEDADE BRASILEIRA DE ZOOTECNIA, 37., Viçosa, 2000. Anais. Viçosa: SBZ, 2000.

BRYANT, H. T.; BLASER, R. E.; HAMMES Jr., R. C.; HARDISON, W. A. 1961 a. Method for increased milk production with rotational grazing. Journal Dairy Science, 44: 1733-1741p.

BROUGHAM, R,W. A studying rate of pasture growth. Australian Journal of Agricultural Research, v. 6, p. 804-812, 1955.

BROUGHAM, R.W. Effect of intensity of defoliation on regrowth of pasture. Australian Journal of Agricultural Research, v. 7, n. 2, p. 377-387, 1956.

BROUGHAM, R.M. Interception of light by the foliage of pure and mixed stands of pasture plants. Australian Journal of Agricultural Research, v.9, p.39-52, 1957.

BROUGHAM, R.W. The effects of frequency and intensity of grazing on the productivity of productivity of a pasture of short-rotation ryegrass and red and white clover. New Zealand Journal of Agricultural Resarch, v. 2, p.1232-1248, 1959.

BROUGHAM, R.W. The effects of frequent hard grazings at different times of the year on the productivity and species yields of a grass-clover pastures. New Zealand Journal of Agricultural Research, v. 3, p.125-136, 1960.

BUXTON, D.R.; FALES, S.L. Plant environment and quality. In: FAHEY Jr., G.C. (Ed.) Forage quality, evaluation, and utilization. Madison: ASA, CSSA, SSSA, 1994. cap. 4, p.155-199. 
CARNEVAlli, R. A.; SIlva, S.C.; CARVAlHO, C.A.B.; ET AL. Desempenho de ovinos e respostas de pastagens de Coastcross submetidas a regimes de desfolha sob lotação contínua. Pesquisa Agropecuária Brasileira., Brasília, v. 36, n. 6, p. 919 927, jun.2001a.

CARNEVAlLI, R. A.; SILVA, S.C.; FAGUNDES, J. L.; ET AL. Desempenho de ovinos e respostas de pastagens de Tyfton 85 (Cynodon spp.) sob lotação contínua. Scientia Agricola., v. 58, n. 1, p.7 -15, 2001 b.

CARVALHO, M.V.B.; SILVA, L. C.; DUBEUX JUNIOR., J.C.B; SANTOS, M.V.F.; FERREIRA, R.L.C. Efeito da idade de corte sobre a produtividade de gramíneas tropicais. In: CONGRESSO NORDETINO DE PRODUÇÃO ANIMAL, 2., Teresina, 2000. Anais. Teresina: Sociedade Nordestina de Produção animal, 2000. p. $78-80$.

CECATO, U., SANTOS, G.L., BARRETO, I.L. Efeito de doses de nitrogênio e alturas de cortes sobre a produção, qualidade e reservas de glicídeos de Setaria anceps Stapf. cv Kazungula. Revista do Centro Ciências Rurais, v.15, n.4, p.367-378, 1985.

CECATO, U.; MARCO, A.A.F.B.; SAKAGUTI, E.S.; DAMASCENO, J.C.; SUZUKI, E.; MEURER, F. Avaliação de cultivares de Panicum maximum Jacq. In: REUNIÃO ANUAL DA SOCIEDADE BRASILEIRA DE ZOOTECNIA, 34., Fortaleza, 1996. Anais. Fortaleza: SBZ, 1996. p. 403-406.

COOPER, J.P. Physiological and morphological advances for forage improvement. In:

INTERNATIONAL GRASSLAND CONGRESS, 14., Lexington, 1981. Proceedings. Boulder: Westview Press, 1983. p. 125-137.

CORREA, L.A.; FREITAS, A.R.; BATISTA, L.A.R. Níveis de nitrogênio e frequências de corte em 12 gramíneas forrageiras tropicais. I - produção de matéria seca (compact disc). In: REUNIÃO ANUAL DA SOCIEDADE BRASILEIRA DE ZOOTECNIA, 35., Botucatu, 1998. Anais. Botucatu: SBZ, 1998.

CORSI, M. Effects of nitrogen rates and harvesting intervals on dry matter productivity, tillering and quality of the tropical grass Panicum maximum (Jacq.). Ohio, EUA: Ohio State University, 1984, 125 p. Tese (PhD). 
CORSI, M. Manejo de plantas forrageiras do gênero Panicum. In: SIMPÓSIO SOBRE MANEJO DA PASTAGEM, 9., 1988, Piracicaba, 1988. Anais. Piracicaba: FEALQ, 1988. p. 57-75.

CORSI, M.; SANTOS, P.M. Potencial de produção de Panicum maximum. In: SIMPÓSIO SOBRE O MANEJO DA PASTAGEM, 12., Piracicaba, 1995. Anais. Piracicaba: FEALQ, 1995. p.275-304.

COSTA, N.L.; OLIVEIRA, J.R.C. Produção de forragem e composição química de Panicum maximum cv. Tobiatã em diferentes idades de corte (compact disc). In: REUNIÃO ANUAL DA SOCIEDADE BRASILEIRA DE ZOOTECNIA, 34., Juiz de Fora, 1997. Anais. Juiz de Fora:SBZ, 1997.

COSTA, M. N. X.; MATTOS, H. B.; DIAS, C. T. S.; BUENO, M. F.; LEITE, W. B. O. Influência de doses e épocas de adubação nitrogenada na produção estacional do capim-Mombaça (compact disc). In: REUNIÃO ANUAL DA SOCIEDADE BRASILEIRA DE ZOOTECNIA, 37., Viçosa, 2000. Anais. Viçosa, SBZ, 2000.

COWARD-LORD, J. Composición química y digestibilidad “in vitro'De diez forrajeras tropicales. Mayagyes, 1972, 47p. Tesis (Maetria) - Universidad de Puerto Rico.

CROWDER, L. V.; CHHEDA H. R. Tropical grassland husbandry. New York: Longman, 1982. 562p.

DERESZ, F.; MOZZER, O. L. Produção de leite em pastagem de capim-elefante. In: CARVAlHO, M. M.; ALVIM, D F.; CARVALHO, L. A . Capim-elefante: produção e utilização. 2 . ed. Brasília: Embrapa - SPI. Juiz de Fora, 1997 p.189-208. EMPRESA BRASILEIRA DE PESQUISA AGROPECUÁRIA. Sistema brasileiro de classificação de solos. Serviço Nacional de Levantamento e Conservação de Solos. Brasília: EMBRAPA produção de informação, 1999. 412p.

EUCLIDES, V. P. B. Valor Alimentício de espécies forrageiras do gênero Panicum. In: SIMPÓSIO SOBRE MANEJO DE PASTAGEM, 12., Piracicaba, 1995. Anais. Piracicaba: FEALQ, 1995. p. 245-274. 
EUCLIDES, V. P.B.; MACEDO, M.C.M.; OLIVEIRA, M. P. Avaliação de cultivares de Panicum maximum em pastejo (compact disc). In: REUNIÃO ANUAL DA SOCIEDADE BRASILEIRA DE ZOOTECNIA, 36., Porto Alegre, 1999. Anais. Porto Alegre: SBZ, 1999.

EUClIDES, V. P.B.; MACEDO, M.C.M.; VIERIRA, A.; OLIVEIRA, M. F. Evaluation of Panicum maximum cultivars under grazing. In: International Grassland Congress, 17., Palmerston North, 1993. Proceedings. Palmerston North: New Zealand Grassland Association, 1993, p.1999-2000.

FAVORETTO, V.; FURTADO, C.E. Efeito do manejo, em quatro alturas distintas, sobre a produção e composição química bromatológica do capim colonião (Panicum maximum Jacq.). Científica., v.6, n.2, p.329-335, 1978.

GERDES, L. Algumas características agronômicas, morfológicas e de valor nutritivo dos capins Marandu, Setária e Tanzânia. Pirassununga, 1999. 81p. Dissertação (Mestrado) - Faculdade de Medicina Veterinária e Zootecnia, Universidade de São Paulo.

GOERING, K.H.; VAN SOEST, P.J. Forage fiber Analysis (apparatus, reagents, procedures, and some application). Washington, D.C.: US Department of Agriculture, 1970. 379 p. (Agricultural Handbook).

GOMES, M. A. Efeitos de intensidade de pastejo e períodos de ocupação da pastagem na massa de forragem e nas perdas e valor nutritivo da matéria seca do CapimMombaça (Panicum maximum Jacq. cv. Mombaça). Pirassununga, 2001, 93p. Dissertação (Mestrado) - Faculdade d eZootecnia e Engenharia de Alimentos, Universidade de São Paulo.

HASSAN, W.E.W., PHIPPS, R.H., OWEN, E. Dry matter yield and nutritive value of improved pastures species in Malaysia. Tropical Agriculture., v.67 n.4, p.303-308, 1990. 
HERLING, V.R.; JANTALIA, C.P.; PIAZZA, C.; SUDA, C.H.; CERQUEIRA, P.H.; LIMA, C.G. Determinação da matéria seca disponível do capim Mombaça (Panicum maximum Jacq. cv. Mombaça) sob pastejo (compact disc). In: REUNIÃO ANUAL DA SOCIEDADE BRASILEIRA DE ZOOTECNIA, 35., Botucatu, 1998. Anais. Botucatu: SBZ, 1998b.

HERLING, V. R.; BRAGA G. J.; LUZ, P. H. C.; OTANI, L. Tobiatã, Tanzânia e Mombaça. In: SIMPÓSIO SOBRE MANEJO DA PASTAGEM, 17; Piracicaba, 2000. Anais. Piracicaba: FEALQ, 2000. p.21-64.

HODGSON, J. ; BIRCHAM, J.S.; GRANT, S.A.; KING, J. The influence of cutting and grazing management on herbage growth and utilization. In : WRIGHT, C.E., Plant Physiology and Herbage Production. Maidenhead: British Grassland Society, 1981, p. 51-62.

HODGSON, J. Grazing management - Science into practice. New Zeland: Longman Scientific \&Techinical, 1990. 203p.

JANK, M. B. Potencial do gênero Panicum. In: SIMPÓSIO BRASILEIRO DE FORRAGEIRAS E PASTAGENS, Campinas, 1994. Anais. Campinas: Comissão Brasileira de Nutrição Animal,1994. p.25-31.

KORTE, C.J.; WATKIN, B.R.; HARRIS,W. Use of residual leaf area index and light interception as criteria for spring-grazing management of a ryegrass-dominant pasture. New Zealand Journal of Agricultural Research, v. 25, p.309-319, 1982.

KORTE, C.J.; WATKIN, B.R.; HARRIS,W. Effects of the timing and intensity of spring grazing on reproductive development, tillering, and herbage production of perennial ryegrass dominant pasture. New Zealand Journal of Agricultural Research, v.27, p.135-149,1984.

MACHADO, A. O.; CECATO, U.; MIRA, R.T.; PEREIRA, L.A.F.; MARTINS, E.N.; DAMASCENO, J.C.; . Avaliação da composição química e digestibilidade in vitro da matéria seca de cultivares e acessos de Panicum maximum Jacq. sob alturas de corte. Revista Brasileira de Zootecnia, v.27, n.5, p.1063, 1998. 
MACHADO, A. O.; CECATO, U.; MIRA, R.T.; PEREIRA, L.A.F.; MARTINS, E.N.; DAMASCENO, J.C.; SANTOS, G.T. Avaliação de genótipos de Panicum maximum (Jacq) em duas alturas de corte (compact disc). In: REUNIÃO ANUAL DA SOCIEDADE BRASILEIRA DE ZOOTECNIA, 34., Juiz de Fora, 1997. Anais. Juiz de Fora:SBZ, 1997.

MARSHALL, C. Physiological aspects of pasture growth. In: SNAYDON, R.W. Managed Grasslands Analytical Studies. New York: Elsevier Science Publishing New York, 1987. 285p.

MOORE, J.E.; MOTT,G.O. Structural inhibitors of quality in tropical grasses. In: MATCHES, A.G. Aty quality components of forage. Madison: CSSA, 1973, n.4, p. 53-98. (Special Publication)

MOORE, J. E. Forage Quality, Evaluation and Utilization. In: NACIONAL CONFERENCE ON FORAGE QUALITY, EVALUATION AND UTILIZATION. Lincoln, 1994. Proceedings. Lincoln: University of Nebraska, 1994, p.967-998: cap.24: Forage Quality Indices: Development and application.

MOTT, G.O. Evaluacion de la produccion de forajes. In: HUGHES, H.D.; HEATH, M.E.; METCALFE, D.S. (Ed.). Forrajes - la ciencia de la agricultura basada en la producción de pastos. México: CECSA, 1970. p. 131-141.

NELSON, C. J.; MOZZER, L.E. Plant factors affecting forage quality. In: FAHEY JUNIOR., G.C. (Ed.), Forage quality, evaluation, and utilization. Madison: ASA, CSSA, SSSA, 1994. cap. 3, p.115-154.

NUNES, S.G.; BOOCK, A.; PENTEADO M.I. de O. et al. Comissão da cultivar Marandu. Campo Grande: CNPGC, 1985. 31p. (Documentos, 21).

OLIVEIRA, T. N.; CARVALHO, M.V.B.A.; DA SILVA, A.L.C.; DUBEUX JUNIOR., J.C.B.; SANTOS, M.V.F.; FERREIRA, R.L.C. Composição química de gramíneas tropicais submetidas a duas frequências de corte. In: REUNIÃO ANUAL DA SOCIEDADE BRASILEIRA DE ZOOTECNIA, 38., Piracicaba, 2001. Anais. Piracicaba:SBZ, 2001. p. 107-109. 
PARSONS, A. J; JOHNSON, I.R.; HARVEY, A. Use of a model to optimize the interaction between frequency and severity of intermitent defoliation to provide a fundamental comparison of the continuous and intermitent defoliation of grass. Grass and Forage Science, v.43, p. 49-59, 1988.

PEDREIRA, J. V. S.; MATTOS, H. B. Crescimento estacional de cultivares de capimelefante. Boletim da Industria Animal, v. 39, p. 29-41, 1982.

PEDREIRA, J.V.S.; SILVEIRA, J.J.N. Variação da composição bromatológica do capim colonião (Panicum maximum Jacq.). Boletim da Industria Animal, v 29, n.1, p. 185-190, 1972.

PINTO, J.C.; GOMIDE, J.A.; MAESTRI, M. Produção de matéria seca e relação folha:caule de gramíneas forrageiras tropicais, cultivadas em vasos, com duas doses de nitrogênio. Revista da Sociedade Brasileira de Zootecnia, v. 23, p.433 - 440, 1994a.

PINTO, J.C.; GOMIDE, J. A.; MAESTRI, M. Produção de matéria seca e relação folha/caule de gramíneas forrageiras tropicais, cultivadas em vasos, com duas doses de nitrogênio. Revista da Sociedade Brasileira de Zootecnia, v. 23, n. 3, p. 313326, 1994 b.

QUEIROZ, D. S.; GOMIDE, J. A.; Avaliação oda folha e do colmo de topo e base de perfilhos de três gramíneas forrageiras. 1. Digestibilidade in vitro e Composição Química. Revista Brasileira de Zootecnia, v. 29, n. 1, p. 53-60, 2000.

RAMOS, A. K. B. Avaliação do crescimento, componentes produtivos e composição mineral de três gramíneas forrageiras tropicais. Piracicaba, 1997. Dissertação (Mestrado). Escola Superior de Agricultura "Luiz de Queiroz" - Universidade de São Paulo.

RÊGO, F.; CECATO, U.; CANTO, M.W. ET AL. Qualidade do capim-Tanzânia (Panicum maximum Jacq. cv. Tanzânia 1) manejado em diferentes alturas, sob pastejo. In: REUNIÃO ANUAL DA SOCIEDADE BRASILEIRA DE ZOOTECNIA, 38., Piracicaba, 2001. Anais. Piracicaba: FEALQ, 2001a p.117-118. 
ROSSETO, F. A. A. Desempenho agronômico de pastagens de capim elefante cv. Guaçu (Pennisetum purpureum Schum.) e capim-Tanzânia (Panicum maximum Jacq.) em sistemas de produção de leite. Piracicaba, 2000. 174p. Dissertação (Mestrado). Escola Superior de Agricultura “Luiz de Queiroz”, Universidade de São Paulo.

SANTOS, P. M. Estudo de características de Panicum maximum (Jacq.) cvs. Tanzânia e Mombaça para estabelecer seu manejo. Piracicaba, 1997. 62p. Dissertação (Mestrado). Escola Superior de Agricultura “Luiz de Queiroz”, Universidade de São Paulo.

SANTOS, P.M. Controle do desenvolvimento das hastes no Capim Tanzânia: um desafio. Piracicaba, 2002. 98p. Tese (Doutorado) - Escola Superior de Agricultura "Luiz de Queiroz", Universidade de São Paulo.

SANTOS, P. M.; CORSI, M.; BALSALOBRE,M. A. A. Efeito da frequência de pastejo e da época do ano sobre a produção e a qualidade em Panicum maximum cvs. Tanzânia e Mombaça. Revista Brasileira de Zootecnia, v.28, n.2, p.244-249, 1999.

SARMENTO, C.M.B.; VEIGA,J.B.; COSTA, N.A.; NETO, M.S.; ALVES,L.N. Avaliação de um sistema de pastejo intensivo em pastagem de Tobiatã (Panicum maximum, BRA 001503). In: REUNIÃO ANUAL DA SOCIEDADE BRASILEIRA DE ZOOTECNIA, 34 Juiz de Fora, 1997. Anais. Juiz de Fora: SBZ, 1997, p.267-270.

SAS. INSTITUTE. Language guide. version 6.03. Ed. Cary, 1989. 530p.

SAVIDAN, Y.H., JANK, L., COSTA, J.C.G. Registro de 25 acessos selecionados de Panicum maximum. Campo Grande: EMBRAPA-CNPGC,1990. 68p. (EMBRAPA-CNPGC, Documentos n, 44).

SINGH, D. K. Effect of cutting management on yield and quality of different selections of guines grass (Panium maximum (Jacq.) L.) in a humid subtropical environment. Tropical Agriculture., v. 72, n. 3, p. 181-187, 1995.

STOBBS, T.H. Factors limiting the nutricional value of grazed tropical pastures for beef and milk production. Tropical Grassland., v. 9, n.2, p. 141-149, 1975. 
TEIXEIRA, E. I. Avaliação de características morfológicas e nutricionais do capimTobiatã (Panicum maximum cv. Tobiatã) sob sistema de pastejo rotacionado. Piracicaba, 1998. 87 p. Dissertação (Mestrado) - Escola Superior "Luiz de Queiroz”, Universidade de São Paulo.

TILLEY, J.M.A., TERRY, R.A. 1963. A two-stage technique for the in vitro digestion of forage crops. Jounal British Grassland., v. 18, p. 104-111, 1963.

UEBELE, M.C. Padrões demográficos de perfilhamento e produção de forragem em pastos de capim-Mombaça submetidos a regimes de lotação intermitente. Piracicaba, 2002. 79p. Dissertação (Mestrado) - Escola Superior de Agricultura "Luiz de Queiroz", Universidade de São Paulo.

VAN SOEST, P.J. Nutricional ecology of the ruminants. New York: Cornell University Press, 1982. 373p.

VANSOEST, P.J. Nutricional ecology of the ruminants. 2. Ed. Ithaca: Cornell University, 1994. 476p.

VAN SOEST, P.J.; LEWIS, B.A. Methods for dietary fiber, neutral detergent fiber and polysaccharides in relation to animal nutrition. Jounal of Dairy Science., v. 74, p. 3583-3597, 1991.

VEIGA, J. B.; MOTT, G. O.; RODRIGUES, L. R. A.; OCUMPAUGH, W. R. Capim elefante anão sob pastejo. II. Valor Nutritivo. Pesquisa Agropecuária Brasileira., v.20, n.8, p.937-44, ago. 1985.

VIEIRA, J. D.; HAAG, H.P.;Corsi, M.;Bose, M.L.V. Produção, coeficiente de digestibilidade da matéria seca e concentração de nutrientes em Panicum maximum Jacq., em função dos cortes aos 30, 45, 60 e 70 dias de idade. Anais da Escola Superior de Agricultura “Luiz de Queiroz", v. 37, p.419-441, 1980.

VICENTE-CHANDLER, J.; CARO-COSTAS R., PEARSON, R.W.; ABRUÑA, F.; FIGARELLA, J.; SILVA, S. The intensive management of tropical foragnes in Puerto Rico. Rio Piedras: Agriculture Experimental Station, 1964. 152p. (Boletim, 187). 
WERNER, J.C. Importância da interação solo-planta-animal na nutrição de ruminantes.

In: CURSO DE ATUALIZAÇÃO EM NUTRIÇÃO ANIMAL. Brasília, 1993. Anais. Brasília: MAARA/SDR/SENA, 1993, v. 1, p. 11-20.

WILSON, D.B.; McGUIRE, W.S. Effects of clipping and nitrogen on competition between three pasture species. Canadian Journal of Plant Science, v. 41, p. 631-642, 1961. 